NBER WORKING PAPER SERIES

\title{
A HECKSCHER-OHLIN VIEW OF SWEDEN COMPETING IN THE GLOBAL MARKETPLACE
}

\author{
Edward E. Leamer \\ Per Lundborg
}

Working Paper No. 5114

\author{
NATIONAL BUREAU OF ECONOMIC RESEARCH \\ 1050 Massachusetts Avenue \\ Cambridge, MA 02138 \\ May 1995
}

Partially supported by NSF grant SBR-9209845. The able research assistance of Torsten Dahlquist, Robert Murdock and Christopher Thornberg is gratefully acknowledged. Pär Hansson has generously given us access to some of his data. We are grateful to Lars Lundberg and Mats Persson and participants at the NBER-SNS conference in Stockholm December 2-4 for comments. This paper is part of NBER's research program in International Trade and Investment. Any opinions expressed are those of the authors and not those of the National Bureau of Economic Research.

(C) 1995 by Edward E. Leamer and Per Lundborg. All rights reserved. Short sections of text, not to exceed two paragraphs, may be quoted without explicit permission provided that full credit, including $\odot$ notice, is given to the source. 
NBER Working Paper \#5114

May 1995

\title{
A HECKSCHER-OHLIN VIEW OF SWEDEN COMPETING IN THE GLOBAL MARKETPLACE
}

\begin{abstract}
In this paper we explore the hypothesis that the Swedish malaise comes from the interaction of the Swedish welfare state with changes in the global marketplace. External commerce can expose Swedish workers in exporting and import-competing industries to a kind of competition from low-wage foreign workers that is incompatible with an extensive welfare system. Incompatibilities between the external marketplace and the welfare state can be amplified over time if the welfare system discourages investments in human and physical capital thus causing a shift in the product mix toward more labor-intensive goods that are produced outside the Swedish borders by lower-wage workers.

The Heckscher-Ohlin theory that is the theoretical foundation of this paper allows a highwage equilibrium without government intervention even though there is increasing competition from low-wage suppliers, if capital is abundant and if production is concentrated on the most capital intensive products. Then the unskilled workers can be employed at high wages either in the tradables sector or the nontradables sector. On the contrary, however, Swedish investment rates have not been high enough to maintain the unique position that it had a couple of decades ago. This we express in the form of the Heckscher-Ohlin Crowding Hypothesis: Swedish difficulties in its interactions with the international marketplace come from an eroding lead in capital abundance.

Though losing its distinctiveness in capital abundance, Sweden remains unusually well supplied with soft-wood forests. These forest resources can be a mixed blessing. Although contributing substantially to Gross Domestic Product, forest resources can also imply lower wages for unskilled workers and consequently greater income inequality. A country with abundant forest resources and also very abundant capital can produce capital intensive manufactures in addition to pulp and paper, but a country with more moderate supplies of capital can find much of its capital deployed in pulp and paper and end up with a mix of tradables that includes some relatively labor-intensive products. This product mix may dictate relatively low wages for unskilled workers since the marginal unskilled worker may be employed in sectors which globally award low wages.
\end{abstract}

Edward E. Leamer

Anderson Graduate School of Management

University of California

405 Hilgard Avenue

Los Angeles, CA 90024-1481

and NBER
Per Lundborg

The Industrial Institute for Economic and Social Research

Box 5501

S-114 85 Stockholm

SWEDEN 


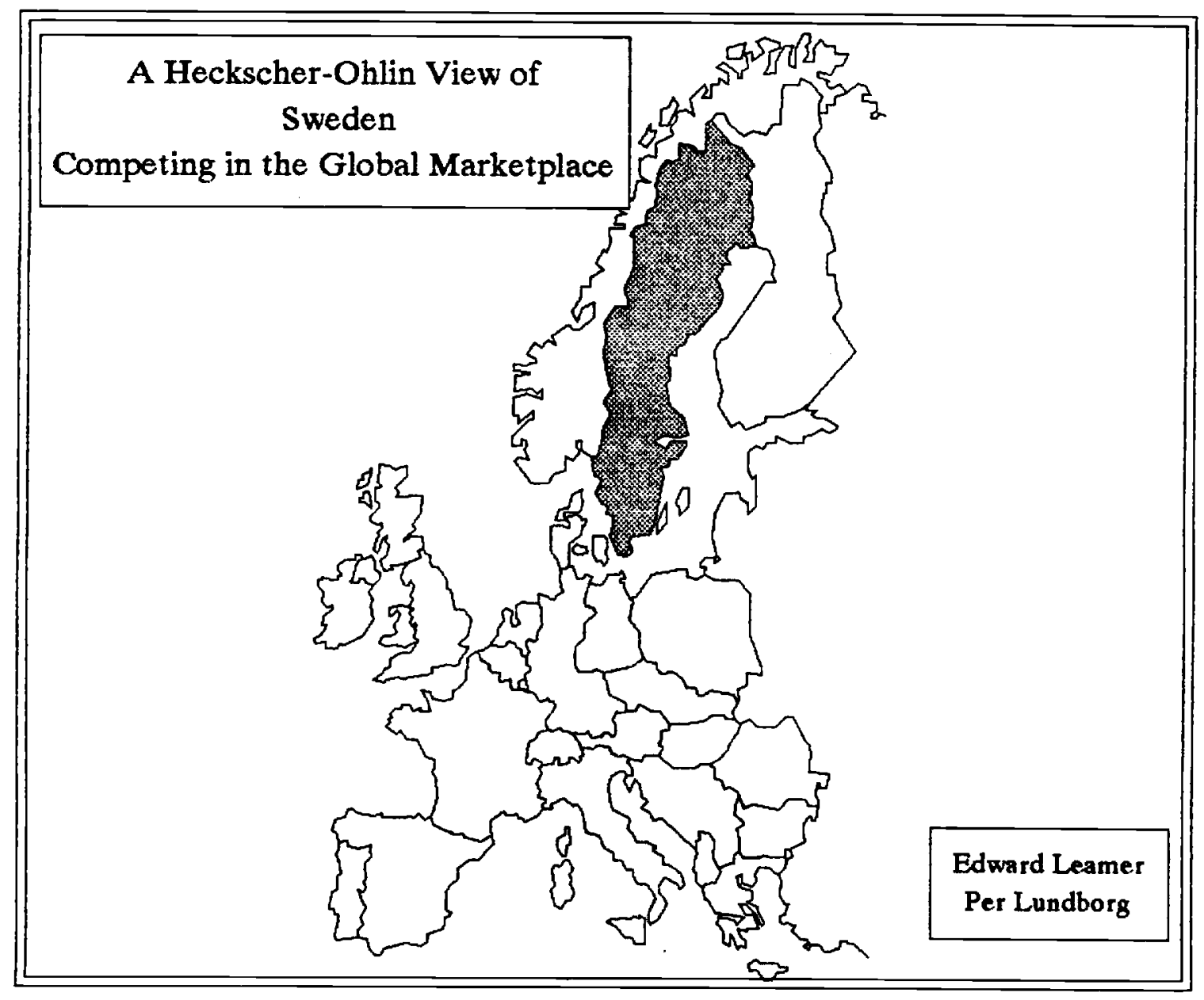




\section{INTRODUCTION}

Besides the extensive welfare state, a salient feature of the Swedish economy is the substantial and long standing degree of international interdependence. Imports as a share of GDP increased from $17 \%$ a few years after World War II to $45 \%$ in the early 1980 :s. This openness places Sweden in a group of countries that are vulnerable to changes in the international marketplace. In this group of small open economies are also the countries with the most extensive welfare states.

When Sweden started down the road to the welfare state it was enjoying very positive growth figures and a favorable competitive situation in international trade. During the 1950:s and 1960:s the growth in government went hand in hand with supporting trends in the basic economic indicators and with substantial increases in Swedish foreign trade. The extended period of economic slowdown that Sweden is experiencing has naturally stimulated a search for the cause, and for appropriate remedies. One of the primary candidates is the size of the public sector and various features of the welfare state which tend to allocate workers to relatively unproductive tasks and which tend to discourage investments in physical and human capital. Another candidate is globalization. After all, the current Swedish economic malaise is unique for Sweden but comes at a time when all the major industrialized countries are experiencing difficulties. A high dependence on the international marketplace seems likely to expose Sweden particularly to external macroeconomic and micro-economic shocks.

In this chapter we explore the hypothesis that the Swedish malaise comes from the interaction of the Swedish welfare state with changes in the global marketplace. The view that we offer here has a time frame which is long enough for underlying micro-economic forces to dominate the shorter term macro-economic disturbances. Among the events that have changed the nature and intensity of international competition and thus the viability of the Swedish welfare system are high rates of capital accumulation in Northern and more recently Southern Europe, the emergence of Asia, the formation of the European Economic Community, the recent liberalization of Eastern Europe, and the rise of the multinational corporation.

The micro-theory of international economics offers three theoretical lenses through which one might view the Swedish economy. These are the Ricardian Theory, the Heckscher-Ohlin (H-O) Theory and the Chamberlainian Theory. The Ricardian model points to technological differences as the source of comparative advantage. ${ }^{2}$ The Chamberlainian model refers to economies of scale and to product differentiation as the

2 If the Ricardian model were used as a guide, we might look to the spread of technological knowledge to Asia as a source of increased competition for Swedish products. It may be possible to characterize the Swedish economy in 1960 as enjoying a Ricardian cost advantage in capital-intensive manufacturing, but in the intervening years, technological knowledge has become footloose and is no longer a source of comparative advantage for Sweden or other industrialized countries. 
explanation of international trade. ${ }^{3}$ An $\mathrm{H}-\mathrm{O}$ model points to supplies of productive inputs as the source of comparative advantage. We present here an $\mathrm{H}-\mathrm{O}$ view, which we think is clear and insightful. We leave the two other lenses on the shelf, not because they aren't useful, but rather because the Heckscher-Ohlin lens offers a view that deserves to be lingered over.

The fundamental insight of a Heckscher-Ohlin model is that international trade in goods can turn a local Swedish labor market into a global labor market with wages selected to assure the international competitiveness of exporting and import-competing industries. There is one exception to this general statement. If the capital intensities of tradeables produced in Sweden are all extreme, then the marginal demand for labor can come from the local nontraded goods sector and Swedish wages can be set in Stockholm. But if the capital intensities of Swedish tradeables are more diverse, then the marginal demand for Swedish workers is external and wages are not set in Stockholm but in Frankfurt, or in Lisbon or in Guandong, depending on the mix of Swedish products. If, to give an extreme example, Sweden had a product mix similar to the Chinese including an active apparel industry, then Swedish wages of unskilled workers could be forced by international competition to the level prevailing in China. Incidentally, it is the mere existence, not the size of a tradable goods sector that matters, since wages in a competitive setting are set on the margin. If the marginal Swedish worker is competing with the Chinese, all Swedish workers in the same skill group are subject to the pressure of Chinese competition, even the Swedish workers that are not making the same products as the Chinese worker.

High wages for unskilled workers and a reasonably low premium for skills can occur, according to the H-O model, if the Swedish product mix is sufficiently capital intensive. A capital-intensive mix of products can occur only if Swedish capital inputs are in sufficient supply compared with Swedish competitors. This identifies our first hypothesis, the Heckscher-Ohlin Crowding Hypothesis: Swedish difficulties in its interactions with the international marketplace come from reduced distinctiveness of its mix of factor supplies, with more competitors on all sides, some offering through international commerce to sell the services of the resources which have been an important traditional source of Swedish comparative advantage, namely human, physical and knowledge capital, and others offering to sell the services of unskilled labor at wage rates that are unconscionable from a Swedish standpoint. ${ }^{4}$

${ }^{3}$ An implication of this type of model is that competition focuses on product differentiation rather than on price cutting. One idea motivated by the Chamberlainian view is that Sweden in 1960 had managed successfully to differentiate its products (Volvo) but over time has had that advantage competed away by the introduction by other countries of close substitutes (Acura and Lexus).

${ }^{4}$ Incidentally, the welfare implications of crowding are clear in a H-O model, but not clear in a Chamberlainian model. Growth in Europe and Asia that crowds the markets for Swedish products causes a deterioration in the terms of trade and reduced Swedish welfare, according to the $\mathrm{H}-\mathrm{O}$ model. But growth outside the borders of Sweden according to a Chamberlainian model allows world-wide production at more efficient scale and greater product variety, both of which can be welfare-improving 
Though losing its distinctiveness in capital abundance, Sweden remains unusually well supplied with soft-wood forests. These forest resources can be a mixed blessing. Although contributing substantially to Gross Domestic Product, forest resources can also imply lower wages for unskilled workers and consequently greater income inequality. A country with abundant forest resources and also very abundant capital can produce capital intensive manufactures in addition to pulp and paper, but a country with more moderate supplies of capital can find most of its capital deployed in pulp and paper and end up with a mix of tradables that includes some relatively labor-intensive products. This product mix may dictate relatively low wages for unskilled workers since the marginal unskilled worker may be employed in sectors which globally award low wages. This notion we call the Forest Product Capital Starving Hypothesis: The forest product sector can starve other manufacturing of human and physical capital, forcing Swedish manufacturing into relatively labor intensive activities. Incidentally, if capital is internationally mobile, the forest product sector can import its capital from abroad and need not starve the rest of manufacturing. While there is some international mobility of capital, Feldstein and Horioka(1980) have shown the remarkable degree of home bias in savings.

The public goods sector, on the other hand, absorbs relatively large amounts of unskilled workers, forcing Swedish manufacturing into activities that are relatively human and physical capital intensive. This notion we call the Public Sector Labor Absorption Hypothesis: The withdrawal of unskilled labor from the manufacturing sector tends to yield a high wage to the unskilled.

Technology and taste interact with factor supplies to determine the gains from trade in an H-O model. A country with an unfortunate mix of factor supplies may find its gains from trade disappearing over time because of changes in technology or taste. For example, the value of comparative advantage in wood and paper will be reduced by shifts toward other building materials or toward the paperless office. The value of comparative advantage in computing equipment is reduced by "commoditization" which changes the technology of production from skill-intensive to unskilled-intensive. Potential changes in technology and taste thus give us two additional hypotheses. Labor Down Grading Hypothesis: Technological change is lowering the skill intensity of Sweden's traditional export products. Inferior Commodity Hypothesis: Global demand is shifting away from Swedish traditional exports.

The $\mathrm{H}-\mathrm{O}$ model can allow mobility of one or more factors of production, in which case the source of comparative advantage rests on the immobile factors. If humans are the immobile factor, a failure to invest adequately in relevant human capital may make Sweden a loser in the world-wide competition for footloose financial/physical capital and footloose knowledge capital. For example, Swedish multinationals that successfully innovate may

even for a country that is not keeping up with the rest of the world in capital accumulation. We repeat again for emphasis that we are offering a Heckscher-Ohlin view, not because it is necessarily correct, but rather because it is rich in insights and not altogether at variance with the facts. We will present measures of intra-industry trade, which increased for many commodities from 1970 to 1985 , a fact which is difficult to square with an $\mathrm{H}-\mathrm{O}$ framework. 
choose to deploy those intangible knowledge assets in foreign locations, possibly increasing foreign employment at the expense of Swedish employment. The increased international mobility of one or more factors of production forms what we will call the Factor Fluidity Hypothesis: Swedish investment in immobile human and physical assets (e.g. education and infrastructure) are not enough to attract substantial amounts of internationally mobile physical and knowledge assets.

Crowding and increased fluidity would generally lead to reduced levels of trade dependence according to an $\mathrm{H}-\mathrm{O}$ model, but over the last several decades there has been a great expansion of trade relative to GDP for all the OECD countries including Sweden. The most obvious explanation is the Shrinking Globe Hypothesis : Decreased costs of transportation(especially air travel), technological revolution in the transmission of information and successive rounds of trade liberalization are bringing Sweden closer to other countries, which opens Swedish markets to new competitors as well as creating new markets for products made in Sweden. ${ }^{5}$

The Ricardian, Chamberlainian and H-O models all allow a high-wage high-growth egalitarian equilibrium without government intervention in international commerce even though there is increasing competition from low-wage Asian, South American, and Southern European suppliers. The Ricardian model points toward technological innovations in process and product as a means of assuring high wages. The Chamberlainian model points to product differentiation and investment in brand name capital. The H-O model relies on capital investment and choice of product mix. According to the $\mathrm{H}-\mathrm{O}$ theory, high wage countries have abundant capital, concentrate production on the most capital intensive products, and absorb unskilled labor into nontradables. But the viability of an $\mathrm{H}-\mathrm{O}$ high-wage solution can be put in jeopardy by crowding, starving, increased fluidity, labor down grading and a shrinking globe, which may jointly be dictating a much higher return to skill than most European labor markets currently allow. This we will call the Discordant Labor Markets Hypothesis: The Swedish system of labor remuneration

3 The 1950:s and the beginning of the 1960:s were characterized by relatively high levels of tariff protection. The creation of EFTA lowered tariffs as did the free trade agreement between EFTA and the EC, in the beginning of the 1970:s. The further tariff cuts of the Kennedy round drastically lowered the trade barriers. Needless to say, these tariff cuts were of importance in stimulating trade, in particular for a small trade dependent country like Sweden.

While tariffs were being lowered, innovations in transportation and communication have greatly reduced the cost of international commerce. Since 1930 ocean transport costs have decreased by $55 \%$, air travel by $80 \%$, and the cost of an overseas telephone call by approximately $98 \%$. However, some empirical estimates of gravity models, e.g. Leamer (1993), do not suggest that the effect of distance on trade patterns has diminished substantially. The greatly increased trade relative to GDP that most countries have experienced is largely explainable by increased dispersion geographically of GDP. Clearly, the least amount of international commerce would take place if all GDP originated in a single country. According to the gravity model, the most amount of trade would occur if world GDP were uniformly distributed across countries. 
which greatly compresses the distribution of wages is becoming increasingly inconsistent with the international marketplace and therefore is increasingly costly to maintain.

The crowding hypothesis, the capital and labor starving hypotheses and the discordant labor markets hypothesis are all extensively discussed in this chapter. Some evidence is given regarding the inferior commodity hypothesis in Section 3.5 where we show that Sweden's comparative advantage has generally been in low-growth sectors. Occasional comments are made about the shrinking globe hypothesis, particularly the more extreme international division of labor that should come from reductions in the costs of international commerce. Only because of limitations on space and energy, the labor down-grading hypothesis and the fluidity hypothesis are not further discussed.

Both two-factor and three-factor models of H-O crowding are presented in Section 2. This sets the stage for an examination in Section 3 of a large amount of diverse data on the behavior of the Swedish economy in relation to other competitor countries. We present no formal econometric estimation or test of a H-O model because to do so would require too great a commitment to a specific model than we are prepared to make. It is better, we think, to be open to substantial amendments of the original model, and to examine the data in ways that will stimulate a search for useful amendments. We thus view the examination of the data more as a puzzle solving exercise than econometric estimation. The $\mathrm{H}-\mathrm{O}$ model defines the rules by which the empirical puzzle can be put together. We think the parts fit together rather well. In particular, in Section 3 we present substantial evidence in support of the H-O Crowding Hypothesis. This evidence takes the form of data on factor supplies of a variety of countries and also information on the competitiveness of the Swedish economy in the international marketplace.

One thing that comes across very clearly in this examination of the data is the longstanding and continuing comparative advantage in forest products. A forest product sector is explicitly introduced in Section 4 where the starving hypothesis is first discussed.

While experiencing crowding and starving. Sweden is attempting to maintain a large public sector and a very low level of income inequality. The role of a public sector and institutional wage setting in maintaining high wages for unskilled workers is discussed in Section 5. Our calculations suggest that employment in the public sector has helped to maintain Swedish wage rates by allowing a relatively capital-intensive mix of traded products. Our discussion of institutional wage setting is strictly theoretical. We argue that the economic liberalizations sweeping the globe have left the world's labor markets saturated with human beings willing to do mundane tasks for extremely low wages. It is not surprising that these international markets are dictating higher compensation for skills especially so in labor-abundant countries. ${ }^{6}$ If Sweden does not have adequate investments in human and physical capital, Sweden will end up producing an increasing labor-intensive mix of tradeables, and Swedish wages will be set in Frankfurt, or in Rome or Beijing, not in Stockholm. Labor market institutions that are designed to resist this trend will prove very costly.

${ }^{6}$ It should be expected that the real retum to physical capital will rise as well, although the current world-wide slowdown has so lowered the demand for capital that the real interest rates on financial capital are now quite low. 
The Heckscher-Ohlin model suggests only one remedy for these problems: Sweden needs much higher rates of physical and human capital formation. With more capital will come naturally higher wages for low-skilled workers. This of course will be helpful, but technological change and globalization together are dictating a much higher degree of income inequality, regardless of the capital abundance of the country. Countries that seek both efficiency and income equality may need to find creative new ways to reward and thereby to encourage effort and investment, without at the same time creating unacceptable inequality.

\section{A HECKSCHER-OHLIN THEORETICAL ECONOMIC HISTORY OF MODERN SWEDEN}

According to the $\mathrm{H}-\mathrm{O}$ model of international comparative advantage, the economic health of a country is determined by its supplies of internationally immobile factors of production including natural resources, workers, knowledge capital and physical capital. The greatest gains from international trade accrue to countries that have relative factor supplies that are very different from the rest of the world. These unusual countries enjoy very favorable terms of trade, exporting products that are dear and importing products that are cheap.

The $\mathrm{H}-\mathrm{O}$ model suggests that changes in the economic health of a country, both absolutely and in comparison with other countries, come from

(1) rapid or slow factor accumulation (e.g. a relatively high investment rate).

(2) technological change which affects some sectors and some factors more than others (e.g., the computer revolution).

(3) shifts in demand (e.g. a building boom affecting the market for lumber).

(4) altered mobility of factors (e.g. increased labor migration associated with the EU membership or increased physical and knowledge capital mobility brought about partly by the increased importance of multinational corporations).

(5) changes in internal institutions (e.g. an increase in the minimum wage) that affect international competitiveness.

In this chapter we focus on the first and last items on this list: capital accumulation and labor market institutions, using them to interpret Sweden's modern economic history beginning after World War II.

It would not be surprising to find Sweden facing increasingly tough competition in the markets for its manufactured products. World War II left Japan and much of Europe with badly damaged capital stocks but relatively undamaged human capital. Countries like the United States and Sweden that emerged from the war relatively intact enjoyed the enormous economic benefits of being able to produce capital intensive products with virtually no competitors. Though trade immediately after the war was limited, European reconstruction, supported by the Marshall plan and foreign investments, was surprisingly rapid, and only a few years after the war exports of most goods were back to their pre-war 
levels. Sweden's geographic proximity to this region of high growth was an important source of it's economic success.

This initial Swedish advantage was rapidly eliminated by the high rates of capital accumulation in Europe and later in Japan. As the rate of human and physical capital accumulation in Sweden continues to lag behind the other European countries, Sweden may find its gains from trade further eroded.

\subsection{A TWO-FACTOR HECKSCHER-OHLIN MODEL}

- The first response by a very capital abundant country to rapid capital accumulation in labor abundant regions of the world is an upgrading of the product mix toward more capital-intensive products. With this product upgrading comes increased imports of labor-intensive manufactures, and improved terms of trade.

- When the opportunities for product upgrading are exhausted, a previously uniquely capital abundant country finds itself in direct competition with foreign suppliers. This competition causes a deterioration in the terms of trade.

A two-factor H-O model with capital and labor as inputs is presented in this section. This model is a good starting point, but it has limitations. First, the model fails to distinguish human from physical capital which is important because the war presumably had a relatively great impact on physical capital. The distinction is also very important for recent history because the international marketplace may be dictating a higher return to human capital compared with raw labor. A second deficiency of this two-factor model is that it makes no reference to natural resources. Sweden enjoys a long-standing comparative advantage in forest products, and no model of Swedish international interactions can be considered adequate without explicit consideration of the forest product sector.

A hypothetical post-war equilibrium of an $\mathrm{H}-\mathrm{O}$ model is illustrated in a Lerner-Pearce diagram, Figure 2.1, on which is drawn the initial unit-cost line and the initial unit value isoquants for the three sectors ordered by increasing capital intensity: apparel, steel and machinery. These unit value isoquants are all tangent to the same unit cost line indicating that the zero profit condition is satisfied for all three products even though the capital abundant countries have factor endowments that are more suited to the capital-intensive products.

The capital scarce countries initially concentrate production on the labor-intensive product, apparel which is shipped to Sweden in exchange for steel and machinery. The initial levels of shipments are not enough to displace production in Sweden, but over time as capital accumulates in the capital-scarce countries, Sweden surrenders the apparel sector and concentrates product mix on steel and machinery. Except for adjustment costs, this is an entirely beneficial transition as the wage rate and the retum to capital are unchanged and the price of apparel falls, making both labor and capital in Sweden better off. This fall in 
the price of apparel is evidenced by an improved terms of trade, apparel being the imported good.

Further capital accumulation in the capital scarce countries in Europe and Asia induces changes that are not so pleasant for Sweden. As capital accumulates in the emerging capital scarce countries, they shift away from apparel production in favor of steel, which shift will be accompanied by a decline in the price of steel, illustrated in Figure 2.2 by the shifting of the unit-value isoquant away from the origin. This price decline lowers the wage rate in Sweden, but it raises the return to capital. Overall, the GDP declines in terms of purchasing power of machinery or apparel but it increases in terms of steel. If Sweden is so capital abundant that production is heavily concentrated on machinery, then steel will be an import item and the price decline would be evidenced by an improving terms of trade. Otherwise the terms of trade declines. This process can go full circle if increases in the supply of machinery in the reemerging nations lower the machinery price and bring all relative prices back to their initial level. Then the comparative advantage that came from having an undamaged capital stock would be completely eliminated.

In summary then, a simple H-O model suggests that the post-war period can be characterized by four phases:

Declining Isolation: Increasing imports and less production of the labor intensive goods. No change in product prices or factor prices.

Initial Distinctiveness: Complete displacement of the labor intensive production. Decline in the price of labor-intensive products but no change in factor earnings. Improved terms of trade. Increased real per capita GDP.

Eroding Distinctiveness: Capital intensive product mix. Relative decline in the prices of moderately capital intensive goods. Decline in the wage rate and increase in the return to capital. Terms of trade deterioration for moderately capital abundant countries and fall in real per capita GDP. Further terms of trade improvements for the most capital abundant countries and corresponding increase in real per capita GDP.

Head to head competition: Capital intensive product mix. Relative decline of the prices of the most capital intensive goods. Increasing wage rate. Terms of trade and real GDP changing in either direction.

This economic drama has been written without parts for Eastern Europe, Latin America and China. The liberalizations that have swept over the globe in the last several years have enormously increased the unskilled labor that is available for economic interaction with Swedish workers. An optimistic scenario would take Sweden back to the period of Initial Distinctiveness as a result of export opportunities in these emerging regions, particularly Eastern and Southern Europe. 


\subsection{A THREE-FACTOR HECKSCHER-OHLIN MODEL}

- The internal labor market premium for human skills is dictated by competition in the international product markets.

- Global capital accumulation can either increase or decrease the skill premium depending especially on where the accumulation takes place.

A three-factor H-O model offers improved understanding of post-war European economic history and also is richer in implications with regard to the relative compensation of skilled and unskilled labor. The three-factor model illustrated in Figure 2.3 has one commodity that uses human capital as an input (chemicals) and three commodities that use only capital and labor (apparel, textiles and machinery) and one commodity that uses only labor(handicrafts). The initial equilibrium that is depicted here occurs in what is termed above the period of initial distinctiveness, namely after the price of apparel has fallen because of increases in global supply. With this relatively low price of apparel, Sweden finds itself in the cone suited to the production of textiles, chemicals and machinery. Germany and Japan are in the moderate wage cone producing apparel, textiles and chemicals. Asia (other than Japan) is very poorly endowed in capital and finds itself in the low-wage cone producing mostly apparel and handicrafts. Sweden has a strong comparative advantage in machinery, but imports chemicals from Germany, and apparel and textiles from Japan, and apparel from Asia (and Southern Europe).

The arrows emanating from the points with the country labels depict hypothetical changes in factor supplies. Sweden, though enjoying an initial advantage from the uniqueness of her endowment mix, finds herself over time crowded on the one side by Japan and the other by Germany. In the meantime, capital accumulation takes Asia into the moderate-wage cone. These changes in factor supplies of Swedish competitors change the world-wide production levels of the five products, which in turn induces compensating price adjustments. These price adjustments alter the Swedish terms of trade and also force changes in the Swedish factor prices including the returns to skill. The terms of trade effect depends on which goods are Swedish export goods and which are import goods. For this discussion, we assume that Sweden is exporting only machinery and importing all the other products, although price reduction in machinery can force Sweden to export either chemicals or textiles, even if there is no change in Swedish production levels.

The effects of product price reductions on Swedish factor prices are summarized in Table 2.1. The message from this table is that although reductions in the price of textiles

${ }^{7}$ The effects of a reduction in the textiles price on the factor earnings in Sweden can be computed in the following way that is more fully explained in Leamer(1987). Extend the line connecting the chemicals point and the machinery point. If a factor input (say labor) is on the same side of this line as the textile point, then the factor and the commodities are "friends" (Ethier's(1984) terminology): a reduction in the price of textiles will lower the return to the factor. The opposite is true for factors with vertices on the other side of the line. As the figure is drawn, in the Swedish cone textiles are a 
and the price of chemicals may both improve the Swedish terms of trade, the reduction in the price of textiles forces Sweden to adopt a higher return to skill in the sense that wage of raw labor must fall and the return to human capital must rise. Also a reduction in the price of machinery causes deterioration in the Swedish terms of trade, and may also increase the skill premium.

The effects of factor accumulation on the output levels in each of the three cones of diversification are indicated in Table 2.2. From this table we can find the kinds of factor accumulation that lead to increased supplies of each of the products. The most difficult effects for Sweden to deal with come from increases in the world-wide supply of machinery, which is the result of physical capital accumulation in the Swedish cone, precisely the final parts of the paths taken hypothetically by Germany and Japan. This final factor accumulation reduces the supply of textiles, but this is likely to be more than offset by the concomitant capital accumulation in Asia, a change which although beneficial from a terms of trade standpoint, increases the skill premium and puts pressure on the Swedish commitment to wage compression.

The expansion of textile production in the tail of the Asia path is a repeat of early Japanese and German history, which according to the figure both begin after the war in the "Japanese cone" selecting the output mix of apparel, textiles and chemicals. Germany, which is relatively well endowed in human capital, has a relatively great supply of chemicals and moves completely out of the production of textiles at relatively low levels of capital per worker.

friend of labor but an enemy of both human and physical capital. Thus a reduction in the price of textiles causes a fall in the wage of raw labor and an increase in the return to both physical and human capital. For the Asian cone, the results are quite different: textiles is an "enemy" commodity for labor and human capital but a friend of physical capital. If the technological inputs are changed some of these conclusions can be substantially altered. For example, if the machinery point is swung to the left selecting a capital/abor ratio less than chemicals, then human capital and textiles become friends for the capital abundant

countries.

Incidentally, a similar phenomenon applies as a country accumulates enough capital to move between the cones: the rate of return to human capital is higher in the Swedish cone than in the Asian cone. This is the case even though Sweden has an abundance of human capital and exports the human capital intensive product (chemicals) to Asia. The reason for this result is that the movement from the Asian cone to the Swedish cone comes about from the accumulation of physical capital not human capital. The complementarity between human skills and physical capital means that the physical capital abundant countries have a higher return to skill. See Davis(1992) for a discussion of the skill premium for a number of countries. 


\subsection{SUMMARY}

It is now time to test these ideas with actual data. The Heckscher-Ohlin theory suggests a careful examination of

a) Relative rates of factor accumulation in Sweden and in other comparison countries.

b) Changes in the Swedish terms of trade.

c) Changes in Swedish trade dependence ratios.

d) Skill premia in the global marketplace.

We are looking particularly for evidence of the Heckscher-Ohlin Crowding Hypothesis. This is the hypothesis that Sweden is being squeezed from three directions. In one direction are the low-wage labor-abundant countries offering to sell labor-intensive goods such as apparel at low prices. In another direction are countries like Japan which are accumulating physical capital rapidly and offering to sell capital-intensive products such as machinery at low prices. And in the third direction are human capital abundant countries like Germany which dominate the skill-intensive sectors such as chemicals. 
Table 2.1

Effects of Price Reductions on Swedish Terms-of-trade, Real Factor Earnings and Skill Premium.

\begin{tabular}{|l|l|l|l|l|l|}
\hline $\begin{array}{l}\text { Reduction in } \\
\text { Price of: }\end{array}$ & $\begin{array}{l}\text { Terms of } \\
\text { Trade }\end{array}$ & $\begin{array}{l}\text { Raw } \\
\text { Labor }\end{array}$ & $\begin{array}{l}\text { Human } \\
\text { Capital }\end{array}$ & $\begin{array}{l}\text { Physical } \\
\text { Capital }\end{array}$ & $\begin{array}{l}\text { Skill } \\
\text { Prem. }\end{array}$ \\
\hline Machinery & - & + & + & - & $?$ \\
\hline Chemicals & + & 0 & - & 0 & - \\
\hline Textiles & + & - & + & + & + \\
\hline Apparel & + & + & + & + & \\
\hline
\end{tabular}

Table 2.2

Effects of Factor Accumulation on Output Levels in Figure 2.3

\begin{tabular}{|c|c|c|c|c|c|}
\hline & Handicrafts & Apparel & Textiles & Machinery & Chemicals \\
\hline \multicolumn{6}{|l|}{ Swedish Cone } \\
\hline Capital & & & - & + & \\
\hline $\begin{array}{l}\text { Human } \\
\text { Capital }\end{array}$ & & & - & - & + \\
\hline Labor & & & + & - & \\
\hline \multicolumn{6}{|l|}{ Japan Cone } \\
\hline Capital & & - & + & & \\
\hline $\begin{array}{l}\text { Human } \\
\text { Capital }\end{array}$ & & + & - & & + \\
\hline Labor & & + & - & & \\
\hline \multicolumn{6}{|l|}{ Asia Cone } \\
\hline Capital & - & + & & & \\
\hline $\begin{array}{l}\text { Human } \\
\text { Capital }\end{array}$ & + & - & & & + \\
\hline Labor & + & & & & \\
\hline
\end{tabular}




\section{EVIDENCE}

\subsection{PRODUCTIVITY AND CAPITAL ACCUMULATION}

\section{Symptom: Swedish Labor Productivity}

- Swedish labor productivity, properly measured, is slipping badly.

As discussed in the introduction to this book, Swedish real output per worker has not been growing as rapidly as many other European countries, but has nonetheless been among the highest. However, this fairly optimistic assessment doesn't hold up if the data are adjusted for variations of the exchange rate from its PPP value. ${ }^{8}$

\section{Symptom: Declining Swedish Shares of OECD Value Added}

- The Swedish share of OECD value added in manufacturing is lagging behind.

Swedish share of OECD manufacturing valued added declined substantially from $1.53 \%$ to $.94 \%$ over the period 1975 to 1983 , at which point a modest recovery set in, lifting the share to $1.15 \%$ in $1990^{\circ}$. Japan had a very expanded market share. But the situation looks even worse if the data include only European countries. Here Sweden drops from a 3.16 share to a $2.60 \%$ share. This puts Sweden with Norway and Italy as the only countries to lose market share over the period.

\section{Disease: Inadequate Physical Capital Accumulation}

- Sweden is not keeping pace in the accumulation of physical capital.

- The slow rate of capital accumulation comes from a low ratio of investment to GDP, high prices of investment goods, and low labor productivity.

One reason why Swedish labor productivity is growing slowly may be inadequate capital accumulation. Capital accumulation per worker can be expressed as the product of

${ }^{8}$ OECD PPP estimates indicate that the Swedish krona was overvalued by as much as $30 \%$ in the late 1960's.

'It should be mentioned that the 1975 base year exaggerates the fall in Sweden's relative position since in this year, value added in Sweden was large compared to that in the OECD area. Most base years would yield a fall in Sweden's position but few as large as 1975 does. 
the investment to GDP ratio, times the relative price of GDP to investment goods times the labor productivity:

INV/WORKER $=($ INV/GDP $)(P G D P / P G D I)((G D P / P G D P) / W O R K E R)$

All three of these factors contribute negatively to the capital accumulation per worker in Sweden. We have already pointed out that Swedish labor productivity growth has been slow. In addition, the Swedish investment share of GDP is low, and the price of investment goods relative to GDP is high ${ }^{10}$.

The investment share of GDP, illustrated in Graph 3.1, is significantly lower than in comparison countries with the exception of the United Kingdom. When in the 1980's the Swedish investment share was around $18 \%$, Germany had about a $22 \%$ share. The rate had been as high as $24 \%$ in the early 1960 's, and the decline in the investment share in the 1980 's is likely to have a continuing negative effect on Swedish capital per worker well into the 20th Century.

In addition to this low investment ratio, Sweden suffers from a high price of investment goods relative to GDP compared with other countries. This price ratio is found by dividing the PPP adjustment factor for investment by the PPP adjustment factor for GDP. Dividing the nominal investment ratio by this price ratio produces the real investment shares depicted in Graph 3.2. The fall in this investment ratio since the 1960's is dramatic and seems certain to have contributed to the performance of the Swedish economy in the 1980 's and 1990's.

The levels of the capital stocks per worker corresponding to these investment data are illustrated in Graph 3.3. ${ }^{11}$ The decline in the Swedish investment rate after 1968 that was evident in Graph 3.2 translates into a very sluggish series on capital per worker depicted in Graph 3.3. Until 1974 Sweden had virtually the highest ratio of capital per worker. But the complete lack of growth in capital per worker from 1977 to 1985 left the Swedish advantage in capital completely eroded, especially in comparison with Spain, Canada and Austria. One other country, the Netherlands, has done worse. Not surprisingly, the Netherlands has experienced very slow growth in GDP per worker.

${ }^{10}$ The three factors should not be looked upon as independent determinants. For instance, while the above text implies that labor productivity affects capital formation, Hjalmarsson and Walfridsson (1992) provide evidence that investments in Swedish manufacturing is a major determinant of labor productivity. Still, it is convenient and useful for descriptive purposes to divide capital accumulation into these three factors.

${ }^{11}$ The capital stocks depicted in Graph 3.3 accumulate investment flows in home currencies using home investment deflators to translate into constant dollar figures. These are then translated into deutschmarks using the 1985 PPP adjusted exchange rate. 


\section{Human Capital Accumulation}

- For a long time Sweden did not keep pace in the accumulation of human capital.

- The share of GDP going to education is high, but not growing like competitors.

- A large fraction of educational expenditures pays for primary and pre-primary education. Tertiary enrollment rates were very low for many years.

Productivity is influenced by human capital accumulation as well as physical capital accumulation. Simple measures based on expenditures on education make it appear that Sweden has been and remains one of the most human capital abundant countries, although European competitors are hot on the Swedish heals. But a different picture emerges if one adjusts for the fact that a large share of Swedish expenditure pays for pre-primary and primary education and relatively little is spent on tertiary education, an allocation which is a reflection of the egalitarian ambitions of the Swedish welfare state. Those ambitions seem increasingly in conflict with global trends in international trade and in technology which are concentrating productivity gains from educational investments on tertiary expenditures.

Graph 3.4 indicates that Swedish educational expenditures as a share of GDP are among the highest in the group of countries considered. Although Swedish expenditures on education seem lavish, a relatively small share goes to tertiary schooling and a particularly large share goes to pre-primary education. This seems especially troubling as changes in technology and in the international marketplace may be dictating higher returns to skill and thus concentrating the returns to schooling at higher levels. ${ }^{12}$ Graph 3.5 compares the Swedish tertiary share of educational expenditures with competitor countries. Sweden is similar to Italy and Germany with low shares. Austria seems to be in a transition from this low group to the more education-oriented countries of Canada and the Netherlands. Graph 3.6 compares expenditures on tertiary education as a share of GDP. Again Sweden falls among the countries with the smallest shares.

The neglect of higher education may show up most clearly in the enrollment rates in tertiary education in Graph 3.7. The jump in the middle of Graph 3.7 comes from a change in the definition of tertiary education to include non-university higher education and adult nighttime schooling. In your mind you should be linking these series either by adjusting upward the pre-1977 data or adjusting downward the post-1976 data. In either case, Sweden is not keeping pace with the increase in investment in higher education in

${ }^{12}$ Wolff and Gittleman (1993), have shown that among the industrial market economies and upper middle income countries, the university enrollment rate is the only variable yielding a significant effect on growth of per capita income. However, this conclusion only applies to the earlier part of the Post war period and none of their educational variables are significant in the latter part of the period. Primary and secondary school enrollment exert positive growth effects in lower middle income and low income countries. 
competitor countries. The difference is whether Sweden is at the very bottom, or only near the bottom. ${ }^{13}$

There are several possible reasons for the Swedish lag in tertiary education. Firstly, the overall number of students admissible for higher education was regulated starting in 1979. This supply constraint clearly affected the number of students during the 1980:s. The university premium is slightly lower in Sweden compared to other countries. As in most other countries, the premium fell from the 1960:s but increased again in the latter half of the 1980:s. This fall, to some extent caused by an increasing supply of university educated relative to high school graduates up to the mid 1980:s, partly explains the fall in demand for higher education. ${ }^{14}$ Furthermore, during decades of high unemployment rates in Europe, Sweden was one of the few countries enjoying full employment, thus raising the opportunity cost of higher education.

That higher unemployment among the young may stimulate university education is also consistent with the most recent enrollment data. While the absolute number of enrolled remained around 150000 for the period 1977 to 1988, it has increased markedly ever since, and in the Fall of 1992 reached $209300^{15}$. In particular, enrollment in the universities of technology has increased: from 19900 in 1977 to 47100 in 1992 and a large part of this increase took place during the last five years.

\section{Factor Supplies in 1965 and 1988}

- In 1965 Sweden had a unique number of people in professional positions and physical capital. The special Swedish position was substantially eroded by 1988 .

Changes in human capital and real capital formation may partly be reflected in a data set compiled by Ligang Song (1993) and Leamer (1984) covering the number of professionals, non-professionals and real capital. Graphs 3.8 and 3.9 display the relative supplies of physical capital, skilled labor (professional and technical) and unskilled labor in the years 1965 and 1988 respectively. Sweden, with a combination of physical capital and large number of professionals, stands away from the pack of other countries in 1965. By 1988 Sweden is closely and hotly pursued by a large number of competitors. The USA which was on the edge of the pack in 1965 is surrounded by competitors in 1988. Japan, in contrast, was way back in the pack in 1965 , but is rushing toward the physical capital vertex as a result of its high investment rate.

${ }^{13}$ International human capital comparisons are notoriously difficult to make. Definitions and periods of measurement differ across countries. Moreover, the structure of education and differences in quality are aspects on human capital that are difficult to consider.

\footnotetext{
${ }^{14}$ See Edin and Holmlund (1992).

${ }^{15}$ See Statistiska meddelanden U 20 SM 9303.
} 
Growth and Capital Accumulation

- Growth rates of labor productivity are closely linked with growth rates of physical and human capital.

Capital accumulation and growth have been linked in a large number of theoretical and empirical papers including the early theoretical contribution of Solow (1956 and 1957) and the more recent empirical work of Barro (1991) and Mankiw, Romer and Weil (1992). The regressions reported in the Table 3.1 compare the growth rates of real GDP per worker for a small sample of countries over three six-year intervals with (a) growth rates of real physical capital per worker, (b) growth rates of real human capital per capita, (c) growth rates of real human capital per worker, and (d) growth rates of total capital per worker. These simple regressions do indicate a link between growth in per capita GDP and physical capital accumulation, but the association of growth with human capital accumulation is hidden if it is there at all. The association seems somewhat better if the measure of abundance is human capital per worker not per capita, but the increase in the $R^{2}$ from 04 to .227 may seem big numerically but is hardly evident in the scatter. (The per capita figure is theoretically preferred if educational expenditures are spread evenly across the population. The per worker figure is theoretically preferred if the educational expenditures are concentrated on the workforce. ${ }^{16}$ ) Although the $\mathbf{R}^{2}$ of the last regression with total capital per worker is inferior to the first with physical capital per worker, the last regression seems preferred because the association is broadly supported by the data set whereas the first association appears to be sensitive to the exclusion of one of several observations. ${ }^{17}$

From these simple regressions, one should not jump to firm conclusions on the relation between capital accumulation and growth. There is obviously some causal force in the opposite direction from growth to capital accumulation; the number of observations is limited; the measurements of capital are imperfect. But it is hard to escape the conclusion that a major reason for poor Swedish growth rates are the problems of factor accumulation.

${ }^{16}$ Keep in mind that the depreciation rate for human capital has been set to $8 \%$ while the depreciation rate for physical capital is set to $15 \%$. This makes the human capital stock much larger and much more sluggish.

${ }^{17}$ The coefficient on the capital stock in the regressions reported in Table 3.2 can be interpreted as the capital share and the intercept is the growth in total factor productivity over the six-year period. The two successful regressions have this growth rate of TFP at about $1 \%$ per year. 


\subsection{NET EXPORTS PER WORKER: TEN TRADE AGGREGATES}

- Sweden has a very significant comparative advantage in forest products. Sweden trades forest products and machinery for labor-intensive manufactures and petroleum.

- The Swedish trade pattern at the level of ten aggregates has been very stable and does not offer dramatic evidence of problems with the Swedish economy. There has been an increase in the net exports of "capital-intensive" manufactures, an aggregate that includes textiles and iron and steel. This represents a half step backward on the ladder of development.

If the $\mathrm{H}-\mathrm{O}$ model is accurate, the factor accumulation patterns ought to be evident in trade patterns to which we now turn. Table 3.2 contains a list of ten aggregates formed from 2-digit SITC commodity groups that have been used in Leamer (1987) to characterize the international patterns of net exports (exports minus imports). These commodity aggregates were formed from observed correlations across countries of the net export levels. For example, countries that tend to export a large amount of cork and wood also export pulp and paper. These accordingly are combined into a forest products aggregate.

The ten aggregates include two natural resource groups (petroleum products (PETRO) and raw materials (MAT)), four crops (forest products (FOR), tropical agricultural products (TROP), animal products (ANL), and cereals (CER)) and four manufactures (labor-intensive (LAB), capital-intensive (CAP), machinery (MACH) and chemicals (CHEM)) In terms of input intensities, these four manufactured aggregates are ordered by physical capital intensities, but chemicals is generally much more intensive in human capital than is machinery. These four manufactured products form a ladder of development which many countries seem to follow, beginning with exports of apparel (LAB), then moving on to textiles and iron and steel (CAP), and finally to machinery (MACH) and chemicals (CHEM).

Net exports per worker of these ten aggregates in 1958, 1965, 1974 and 1988 for Sweden, Germany, the United States and Japan are illustrated in Graphs 3.10-3.13. ${ }^{18}$ The scales are the same in 1958 and 1965, but are larger in 1974 and larger still in 1988. These data conform rather well with the three-factor $\mathrm{H}-\mathrm{O}$ history described in Section 2. In 1958 the United States is not particularly trade dependent and is exporting the full range of manufactured products, especially machinery. Germany has already escaped the ravages of the war, exporting the full range of manufactured products, and importing all the crops and raw materials. Japan, presumably because of the incompleteness of recovery, is hardly participating in international trade, but has a comparative advantage in manufactures concentrated lower on the development ladder (LAB and CAP).

The Swedish trade pattern in 1958 is particularly interesting since net exports are completely concentrated on forest products. About $\$ 200$ per worker of forest products net exports paid for a mixed bag of imports including especially petroleum, tropical agricultural

${ }^{18}$ Data assembled by Ligang Song(1993) and in Leamer(1987). 
products, labor intensive manufactures and chemicals. This Swedish trade pattern is in conflict with the 3-factor $\mathrm{H}-\mathrm{O}$ theory which led us to expect at least a temporary comparative advantage in capital intensive manufactures. The defect of that theory is that it excludes natural resources as an input. What seemed to be happening in Sweden during this period is that the large export earnings from forest products were supporting the imports of everything else, including the full range of manufactures. Incidentally, the United States has an analogous comparative advantage in cereals. Among the manufactures, Sweden was least dependent on machinery which emerges as an export item in the next graph. In the next graphs you can see this machinery sector emerge.

From 1958 to 1965 there was a substantial increase in the amount of trade. Both Germany and the USA "climbed the ladder of development" in the sense that they became net importers of the labor intensive manufactures. The U.S. became a net importer of the capital intensive manufactures as well. Japan by 1965 is emerging as a major global competitor in manufactures, concentrating low on the ladder of development by exporting labor-intensive manufactures but not chemicals. For Sweden, forest products exports per worker increased from $\$ 200$ to $\$ 300$, and the machinery sector is just beginning to emerge by 1965 with positive net exports. By 1974, the emergence of the machinery sector in Swedish net exports is very pronounced. The big increase in the price of petroleum is evident in all four countries with greatly increased petroleum imports. In Sweden, this petroleum bill was paid with greatly increased exports of forest products and also machinery. Otherwise the 1974 picture is very similar to the 1965 picture, although you can see Japan in 1974 starting to give up on labor intensive manufactures.

From 1974 to 1988, both German and Japanese exports of machinery increased enormously, apparently pushing Sweden a half step backward into greater reliance on CAP (principally iron and steel) net exports. The United States is basically knocked on the mat by this competition, and ends up looking like an agrarian society with also enough human capital to support a very modestly successful chemicals sector. Unless the trade deficit apparent in this graph is offset by receipts for services, the U.S. 1988 pattern seems unsustainable, and we should be expecting a correction, probably in the machinery category.

The U.S. pattern in 1965 is rather similar to the Swedish pattern in 1988. Both have one crop that is a substantial source of export receipts. For Sweden it is forest products; for the U.S. it is cereals. Both countries export a capital intensive mix of manufactures in addition to the crop. The United States goes through a dramatic change, switching from being a net exporter to a net importer of machinery.

Graph 3.14 to 3.18 report these net export data for a large number of countries, comparing 1965 with 1988 with both an overall view and a zoomed view of the countries with smaller trade dependence levels. Take a look first at the forest products graph 3.14. If there were no change in comparative advantage from 1965 to 1988 these data would all lie on a straight line. If you flip through these graphs you will discover that forest products has a very permanent comparative advantage in the sense that the points are most close to forming a straight line. The big exporters of forest products in both years were Finland, Sweden and Canada. Iceland was a big importer. The smaller traders generally did not 
change the sign of their next exports. Norway experienced the most substantial change, switching from being a large net exporter to a large net importer.

Contrasting clearly with the apparent permanence of the pattern of forest products trade, the data on trade in labor-intensive manufactures in Graph 3.15 do reveal major changes in the international division of labor with many countries switching from importing to exporting and four switching the other way. Sweden seems relatively unaffected by this turmoil, sitting in a pack of similar countries that were fairly significant importers in both periods, probably enjoying the favorable price trends caused by increased worldwide supply. This long-standing comparative disadvantage in labor-intensive manufactures suggests that Swedish workers are not competing with the Chinese or even the Southern Europeans.

The Swedish experience with capital intensive trade illustrated in Graph 3.16 does indicate a major change in comparative advantage since Sweden switched from being a significant importer to a significant exporter. The major commodities in this group are textiles and iron and steel. This Swedish gain in comparative advantage may come from relatively slow growth of human and physical capital which is forcing exports into these not-too capital intensive items. In this capital-intensive aggregate, Sweden faces traditional competition from Belgium, Japan and Germany, but also new competition from a long list emerging exporters including Taiwan, Korea, Argentina, Spain and Brazil.

The machinery aggregate depicted in Graph 3.17 is characterized by large expansions of exports by Sweden, Japan and Germany, and the emergence of Taiwan and Ireland, at a time when France, Italy, the United Kingdom, and the USA are being forced out of the category. In sharp contrast with the two previous graphs, here there are only two emerging competitors in the machinery category: Taiwan and Ireland.

Graph 3.18 indicates that Sweden continues to be a major net importer of chemicals, which is the most physical/human capital intensive aggregate and exported by the most advanced countries including Switzerland, Netherlands, Germany, the USA, France and the UK. The Swedish experience with chemicals contrasts with the performance of Ireland, Israel, Canada and Norway which emerged as net exporters of chemicals. The experience with chemicals of the major forest product exporters is interestingly diverse. Canada emerged as an exporter of chemicals while retaining a comparative advantage in forest products. Norway surrendered her traditional comparative advantage in forest products over this period in favor of chemicals. But Sweden and Finland are stuck with forest products. We believe that these diverse responses are symptomatic of the different rates of human capital formation in these countries.

In summary, the Swedish trade dependence on exports of capital-intensive manufactures and the absence of exports of chemicals suggests that Swedish wage setting is drifting south, not to China or to other low-wage Asia since Sweden is not at all dependent on labor-intensive manufactures. But in capital-intensive manufactures Sweden is exposed to competition from a growing list low-wage exporters including Taiwan, Korea, Argentina, Spain and Brazil. 


\subsection{Manufacturng Trade Dependence Ratios, 4-DigIt DETAIl}

- Globalization is very evident in Swedish manufacturing as the trade dependence ratios went from $30 \%$ on average to $48 \%$ between 1970 and 1989 .

- Gains in initial comparative advantage came in some resource intensive sectors (pulp and paper), and a moderately capital intensive sector(iron and steel).

- Comparative advantage emerged in some human capital intensive sectors (drugs and medicine, professional and scientific equipment, chemicals, nec). A very capital intensive sector(petroleum refineries) almost emerged with a positive trade balance.

- Increases in initial comparative disadvantage come in wearing apparel, footwear, knitting mills, tires and tubes.

- Comparative disadvantage emerged in office and computing equipment.

Table 3.3 reports data at five different points in time on Swedish exports, imports and net exports of manufactured goods all relative to Swedish apparent consumption. Commodities are subclassified depending on the behavior of these trade ratios. The globalizing sectors have increasing ratios of both exports and imports to consumption. The localizing sectors have reductions in both ratios. The Swedish winners have increases in the ratio of exports to consumption and reductions in the ratio of imports to consumption. The Swedish losers have decreasing export/consumption ratios and increasing import/consumption ratios. Within each of these categories, the data are sorted by the change in the trade balance relative to consumption.

The same data are displayed in Table 3.4 but without dividing by the consumption levels. Here the data are sorted within category by the change in the net export levels. This makes the economically larger sectors stand out, whereas the data scaled by consumption put every sector on an equal footing.

The news here is globalization. In the vast majority of sectors, both the import ratio and the export ratio increased from 1970 to 1989 . Among the globalizing sectors, the average ratio of exports to consumption increased over this period from 25 per cent to 48 per cent, and the average import ratio increased from 34 per cent to 54 per cent.

\section{Most Improving Swedish Performance in the Globalizing Industries}

Sectors which are at the top of both lists have added substantially to Swedish export earnings, and have experienced a much larger change in exports relative to consumption compared with imports relative to consumption. These are especially drugs and 
medicine, pulp and paper, nec., professional and scientific equipment, and chemicals, nec.

Pulp and paper (3411), and motor vehicles and machinery, nec., have added substantially to Swedish export earnings (Table 3.4) but have mixed performance indices reported in Table 3.3. In both cases the level of imports has grown rapidly, although from a very low base in the case of pulp and paper.

\section{Most Deteriorating Swedish Performance in the Globalizing Industries}

Wearing apparel and footwear are the only major sectors that are clearly moving out of Sweden. The import to consumption ratio in apparel increased from $31 \%$ to $87 \%$ while the export ratio held pretty constant at around $10 \%$ and consumption was unchanged. The import to consumption ratio in footwear increased from $56 \%$ to $99 \%$.

Industrial chemicals, fabricated metal, nec., synthetic resins, and electrical apparatus nec all had substantial increases in an unfavorable trade balance, but they have mixed revealed comparative advantage measures because exports grew at least as fast as imports, though from a smaller base.

Shipbuilding was one of the major export items in 1970, but had imports and exports about in balance in 1980 .

\section{Swedish winners}

Iron and steel, and petroleum refineries are clear Swedish winners, with substantial improvement in the trade balance and with exports growing much faster than consumption which in turn grew more rapidly than imports.

Animal feeds is one of those mixed sectors, a winner in the sense of having export growth exceeding import growth, but nevertheless the net trade balance deteriorates.

\section{Swedish losers}

The big losers are office and computing equipment, knitting mills, and tires and tubes.

Sawmills and special industrial machinery are mixed sectors with imports growing more rapidly than exports but with an improvement in the trade balance. 


\subsection{SWEDISH SECTORAL SHARES OF OECD PRODUCTION}

- The increased international division of labor from 1970 and 1990 is evident in a more extreme sectoral distribution of Swedish output with much more wood and paper compared with other OECD countries and with much less output of labor intensive consumer goods.

- The gain in relative market share of the moderately capital intensive sector, iron and steel, is very substantial.

- Offsetting that gain in iron and steel are losses in machinery and in industrial chemicals.

The composition of output in Sweden in comparison with other OECD countries is reported in Table 3.5. The data reported here are the Swedish sectoral share divided by the Swedish overall share, which will be called the Revealed Comparative Advantage Multiple (RCAM). An RCAM exceeding one indicates a sector in which Sweden has a revealed comparative advantage in the sense that the Swedish share of that sector is above the Swedish average. In this table sectors are first divided into those with 1970 numbers exceeding and falling short of one. Then they are sorted by the ratio of 1990 share to 1970 share which is reported in the last column. At the top of each subcategory are those sectors that had the greatest gains in comparative advantage. At the bottom of each subcategory are the sectors with the biggest deterioration. If there were merely an increase in trade dependence from a shrinking globe with no substantial change in comparative advantage, then the ratios in the last column would all exceed one for the commodities with a 1970 comparative advantage, and all fall short of one for the commodities with a 1970 comparative disadvantage. As a matter of fact, there seems to be quite a bit of shuffling of comparative advantage with several sectors switching from one side of one to the other.

The sectors that conform to the simple shrinking globe hypothesis fall at the top and the bottom of the list in Table 3.5. Wood and paper head the list with a substantial RCAM in 1970 and with an amplification of that comparative advantage in 1980. At the bottom of this list are the other kind of product which began with a very weak Swedish comparative advantage, which deteriorated even further. These include wearing apparel, footwear, leather products, textiles, pottery and glass.

The Swedish 1970 comparative advantage in several products dissipated by 1990 . Furniture and printing are examples, as are machinery and industrial chemicals.

Offsetting these losses are gains in sectors which did not enjoy a comparative advantage in 1970. Most noticeably is the behavior of iron and steel which went from a .86 ratio to a 1.46 ratio. Other food, and nonferrous metal also managed to switch from a position of comparative disadvantage to a position of comparative advantage. 


\subsection{OECD PRODUCT MIX}

- Sweden's comparative advantage is generally in low-growth sectors. Where there was initial comparative advantage in high-growth sectors, Sweden did not participate.

- The trends in OECD product mix and in Swedish revealed comparative advantage are very consistent with the Heckscher-Ohlin crowding model, with Sweden squeezed on the one side by low-wage labor-abundant countries and on the other by high-growth capital-abundant countries.

While Sweden was undergoing changes in product mix compared with other OECD countries, the product mix of OECD output was also changing substantially. Table 3.6 indicates the ratio of 1990 OECD share of value added to 1975 share of value added for two-digit ISIC categories. The OECD was shifting value added into plastics, nec., other chemicals, printing and publishing, electrical machinery, and professional equipment. The OECD was shifting value-added out of footwear, leather, wearing apparel, iron and steel, textiles, and petroleum refineries.

These changes in value added shares can come from three sources:

(a) Shifts in demand, associated with things like increases in per capita incomes or changing demographics.

(b) Technological change such as the computer revolution.

(c) Changes in the division of labor between OECD and non-OECD countries.

It is impossible from an examination of this table alone to determine which of these forces predominates, but it is possible nonetheless to speculate. The increases in the importance of electrical machinery presumably reflects the computer revolution. The loss in "industrial chemicals" is more than offset by a gain in "other chemicals" which seems like a classification phenomenon. Wearing apparel, leather products, footwear, textiles, and iron and steel are probably being outsourced.

Swedish comparative advantage in 1970 was generally concentrated in sectors that experienced sluggish growth of OECD value added. An important exception is printing and publishing which grew from an OECD share of value added in 1970 of $4.52 \%$ to $5.99 \%$ in 1990 . However, Sweden did not participate in this growth and failed to maintain its comparative advantage, slipping from a 1.32 Revealed Comparative $A$ dvantage $M u l t i p l e$ (RCAM reported in Table 3.5) to a multiple of . 94 in 1990. Another exception is machinery which grew from an OECD share of $11.71 \%$ to an OECD share of $12.46 \%$. But again Sweden fell behind, with an RCAM falling from 1.25 in 1970 to .99 in 1990.

The other high-growth sectors in Table 3.6 are all sectors in which Sweden had an early comparative disadvantage as measured by the Swedish share of production compared with the OECD share overall, numbers that are reported in Table 3.5. Plastics had a steady RCAM equal to .44 in 1970 and .46 in 1990 . Electrical machinery had a deteriorating RCAM equal to .72 in 1970 and .69 in 1990 . The RCAM for other chemicals which began low did improve, but this was offset by an opposite movement in industrial chemicals. 
The two sectors in which Sweden had a substantial relative comparative advantage in 1970 didn't do so well. The paper sector held pretty steady at around $3.4 \%$ of OECD value added. Wood declined from a $1.76 \%$ share to $1.5 \%$.

The big Swedish winner, iron and steel, which went from an RCAM of .86 to an RCAM of 1.46 was a sector of greatly declining importance in the OECD dropping from a $5.24 \%$ share to $23.53 \%$ share.

From these data one gets the impression of an economy that is sitting on the sidelines watching the growth of printing and publishing, and electrical machinery but holding on to iron and steel even as it declines in importance in the OECD. The dynamism of the Swedish economy is evident only in one negative way. Sweden is letting go of the laborintensive sectors, (footwear, leather products and wearing apparel) even more rapidly than the OECD generally. These trends are very compatible with the $\mathrm{H}-\mathrm{O}$ model with Sweden being squeezed on the one side by low-wage non-OECD (Asia and Northern Africa) producers offering labor intensive goods at low prices and on the other side by the industrialized world which is generally making physical and human capital investments at rates much in excess of Sweden. These competitive pressures force Sweden out of the markets for the most labor-intensive products and also out of the markets for the most capital-intensive products, leaving Sweden in the middle producing moderately capitalintensive goods like iron and steel in addition to the forest-related products.

\subsection{TERMS OF TRADE}

- The overall Swedish terms of trade is driven more by the relative price of forest products to oil, than the relative price of capital-intensive to labor-intensive manufactures.

${ }^{\circ}$ Other than the price behavior of petroleum and the forest product sectors, the external changes in relative prices are generally consistent with the $\mathrm{H}-\mathrm{O}$ crowding hypothesis: Lower prices for imported labor-intensive products (apparel), lower prices for exports of the most capital intensive products (chemicals and machinery) and improved prices for moderately capital intensive goods (iron and steel, transportation equipment and professional equipment).

According to the $\mathrm{H}-\mathrm{O}$ model, the effects of nationally uneven rates of growth of factors are transmitted internationally by product price changes and only by product price changes. Relative price variability is thus a key component of the Heckscher-Ohlin Crowding Hypothesis and if we cannot find the right kind of price changes, all the supportive evidence so far discussed is put in doubt.

The theory and evidence heretofore presented do not leave a very clear picture of what should be expected regarding Sweden's overall terms of trade. A simple H-O model with several goods but only two factors - capital and labor - would lead us to expect a period of improving terms of trade following the war after which there would be a period of terms of 
trade deterioration as the markets for Swedish capital intensive manufactured goods get crowded with competitors. In fact, because of the substantial comparative advantage in forest products, Sweden did not have positive net exports of any of the four manufactures aggregates displayed in Graphs $3.10-3.13$. For that reason the early performance of the terms of trade is greatly influenced by the price of forest-related products. Later, the wild swings in petroleum prices (a major import item) greatly affect the terms of trade. Changes in the relative prices of the manufactured goods, which are a critical feature of the Heckscher-Ohlin Crowding Hypothesis, are thus not likely to show up clearly in the overall terms of trade. With these caveats in mind, we briefly examine the overall terms of trade, and then discuss the more relevant disaggregated data.

Immediately after the war, when demand from the destitute countries was targeted at Sweden and a few other capital abundant countries, Sweden's terms of trade improved dramatically (Graph 3.19), largely because of higher prices for Swedish forest products. Thereafter, the terms of trade has hovered around a constant level though with dips in 1951-1956, 1973, and 1976-82, the first dip due to price reductions for forest products and the latter two dips associated with increases in the price of imported petroleum. After the phase of reconstruction in Europe and during the increased competition in capital intensive goods, we might expect Sweden to experience a decline in its terms of trade. The terms of trade did fall from 1951 to 1956 , but the change is by no means dramatic possibly because of lower prices for imported labor intensive products. ${ }^{29}$

The terms of trade excluding oil is indicated by the broken line in Graph 3.19. This adjustment of course does not account for the indirect effects of oil price hikes, e.g. those implying higher relative prices of oil intensive goods are not accounted for. Still, adjusting only for these direct effects by disregarding oil in the terms of trade calculations gives rise to a generally less volatile terms of trade. In particular, the drop in terms of trade after 1979 is not as pronounced and in the early 1990:s, oil prices do not have much effect on the terms of trade.

Clearly the evidence in favor of the Heckscher-Ohlin crowding hypothesis is slight in the overall terms of trade, but understandably so, since the overall relative price of exports to imports is driven by the prices of forest products exports relative to the price of petroleum imports. Greater detail on the behavior of import and export prices is revealed in Graphs 3.20 and 3.21, the first graph applying to two-digit aggregates and the second to three-digit components of ISIC 38: Machinery and ISIC 37: Metals. In each of these graphs the import price index $(1968=100)$ is on the horizontal axis and the export price index on the vertical axis. The upper panel has the pre-recession 1989 data and the lower panel the 1992 data. There are two aspects of these graphs that should attract your attention. First is the amount of spread along the 45 degree line and second is the identity of the points lying off the 45 degree line. If products were homogenous then import and

${ }^{19}$ Incidentally, these relative prices have to be interpreted with care. High prices for exports are desirable if substantial sales are occurring at these prices, but exchange rate appreciations can temporarily drive up the relative price of exports and give a misleading impression of improved economic health. 
export prices would be identical and all these points would lie on the 45 degree line. The points to the upper right would then indicate commodities which had relative price increases and the points to the lower left commodities with relative price reductions. If the import and export aggregates are very different in composition, then the points in the graph can lie substantially off the 45 degree line.

Thus from the upper panel of Graph 3.20 can be seen the increase in the relative price of pulp and paper and the reduction in the relative price of food products and textiles and apparel. The point representing textiles and apparel is substantially off the $\mathbf{4 5}$ degree line with import prices keeping up much better than export prices. Chemicals is quite extreme in that regard, with the very largest increase in import prices and the very lowest increase in export prices. In words, Sweden is exporting increasingly low-priced chemicals and importing increasingly high-priced chemicals.

A comparison of the upper and the lower panels of Graph 3.20 shows how much the recession affected relative prices with metals prices falling by about 10 percent and prices of pulp and paper exports falling by about 20 percent.

The three-digit detail for metals and machinery is provided in Graph 3.21. From 1968 to 1989 there was a substantial relative price decline of electrical machinery, and a substantial relative price increase in iron and steel and in transportation equipment. The relative export price of measuring devices rose substantially while relative import prices were relatively constant. As in Graph 3.21, the contrast between the upper and lower panel indicates the impact of the recession with iron and steel prices plummeting.

In summary, the external changes in relative prices partly confirms the Heckscher-Ohlin crowding hypothesis: Lower prices for imported labor-intensive products(Textiles and apparel), lower prices for exports of the most capital intensive products (like chemicals and basic metal industries) and improved prices for moderately capital intensive goods (like transportation equipment).

An exception to a general fall in the export prices of the capital intensive goods is pulp and paper. Here the Japanese and German build ups of real and human capital stocks has had no price pressing effect since these countries lack the natural resources to support large scale forest industries. Obviously, it has been profitable for Swedish firms to expand further the forest based industries.

\subsection{INTRA-INDUSTRY TRADE}

The $\mathrm{H}-\mathrm{O}$ model is commonly criticized for its failure to account for intra-industry trade: exports offsetting imports for finely defined categories of commodities. We report in this section sectoral details regarding Swedish intra-industry trade as a form of criticism of our $\mathrm{H}-\mathrm{O}$ view.

A standard measure of intra-industy trade in industry $i$ is

$$
I I T_{\mathrm{i}}=1-\mid \text { Exports }_{\mathrm{i}}-\text { Imports }_{\mathrm{i}} \mid /\left(\text { Exports }_{\mathrm{i}}+\text { Imports }_{\mathrm{i}}\right)
$$


which takes on a value between zero and one, zero if either exports or imports are zero, and one if exports and imports exactly balance.

We report in Table 3.7, the proportion of H-O trade, defined as 1 - IIT. Commodities in this table are sorted by their 1985 levels of H-O trade. At the top of the list is pulp and paper, with such a small level of imports compared with exports that $92 \%$ of trade in 1985 was Heckscher-Ohlin Trade. Next on the list with mostly H-O trade are agricultural products, other forest products, and labor intensive manufactures. At the other end of the list are commodities with imports and exports almost exactly offsetting each other. Chemicals, n.e.c., cordage and rope, professional and scientific, and electrical industrial machinery, all had $\mathrm{H}-\mathrm{O}$ trade less than $1 \%$ in 1985 .

A quick glance at this table might seem very troubling for our $\mathrm{H}-\mathrm{O}$ view, since according to these numbers three-fourths of these commodity aggregates had more intraindustry trade than $\mathrm{H}-\mathrm{O}$ trade. But keep in mind that at the highest level of aggregation, the trade balance condition, Exports = Imports, implies an H-O share of zero. The higher the level of aggregation, the more likely are the aggregates to include some products that are $\mathrm{H}-\mathrm{O}$ exports and some products that are $\mathrm{H}-\mathrm{O}$ imports. Thus measured $\mathrm{H}-\mathrm{O}$ trade will necessarily decline with aggregation. The numbers in Table 3.7 should therefore be viewed with alarm only if the commodities are finely enough, a condition which must be subjectively assessed. Textiles, for example, is a notoriously broad class, with some crude cloth made by very labor intensive methods and other highly specialized fabrics made with great amounts of human and physical capital. Many of these other aggregates are capable of the same interpretation.

What is not so cavalierly dismissed is the general increase over time in IIT trade and the reduction in $\mathrm{H}-\mathrm{O}$ trade. The average level of $\mathrm{H}-\mathrm{O}$ trade declined from $30.5 \%$ in 1970 to $13.2 \%$ in 1985 , but recovered to $18.3 \%$ in 1989 . Though the big increase in world trade relative to GDP over the last several decades is a quite understandable consequence of the lowering of natural and manmade barriers to trade regardless of the theory of trade, a H-O model would not lead us to expect an increase in ITT trade unless there were something perverse about the commodity categories. We are inclined to make the sweeping conclusion from this table that scale economies and product differentiation were an important aspect of the expansion of trade into the 1980's, but perhaps the increase in $\mathrm{H}-\mathrm{O}$ trade from 1985 to 1989 signals a reversion to H-O trade as North-South trade between developed and developing countries is displacing East-West trade among developed countries. 


\section{SWEDISH FOREST RESOURCES}

\subsection{FOREST RESOURCES IN A HECKSCHER-OHLIN MODEL}

- Capital that is used in the Swedish forest product sector is unavailable for the rest of manufacturing. The use of capital in the Swedish forest products sector can starve manufacturing of capital that would otherwise be used to upgrade the product mix and thereby support higher wages.

- The extraction of labor and capital into the forest products sector lowers the capital intensity of resources available to manufacturing by 21 per cent from 170 thousand kronors per worker to 135 thousand kronors per worker.

- Earnings from forest resources generate demand for importables which contributes to the Swedish dependence on imports of other manufactured goods.

The $\mathrm{H}-\mathrm{O}$ model in Section 2 has labor, physical capital and human capital as inputs. The heavy dependence of Sweden on exports of wood, paper and pulp suggests that forest resources need to be explicitly included when the model is applied to Sweden. A multicone model that is inspired by the graphs of net exports of the ten aggregates is illustrated in Figure 4.1. The inputs are labor, (human and physical) capital and forests. A labor intensive forest product (lumber) and a capital intensive forest product (paper) are included. Along the horizontal are the four manufactures: Apparel, Textiles, Machinery and Chemicals. By the way, if pulp were costlessly transportable, then forest resources would not be a source of comparative advantage in paper production, and in this diagram it would be appropriate to locate the paper point along the horizontal with the other manufactures that use only labor and capital as inputs. Paper, pulp and lumber historically have had a strong locational interconnection, although according to Leamer $(1987, p 74)$ paper became more footloose by 1978 , the end of the period he studied. ${ }^{20}$

Figure 4.1 has Sweden in 1945 positioned in the cone that selects as outputs both forest products and also the moderately capital intensive manufacture, textiles. With Swedish capital accumulation comes a shift in the mix of forest products toward paper, and a shift in the mix of manufactures from textiles to machinery. Although Sweden then produces textiles and machinery, the output levels may leave Sweden an importer of these manufactured products. Indeed this is what the data indicate, with positive net exports of machinery not emerging until the early 1960 's. Another way of saying this is that earnings from exports of forest products may generate so much demand for other manufactured

${ }^{20}$ As an exercise, the reader may wish to trace of the model in which forests are not a source of comparative advantage in paper production. 
importables that Sweden imports them all, even though Sweden has a relatively high capital/abor ratio in manufactures.

In this figure, Germany is much more poorly endowed in forest products and concentrates production on the set of manufactures that have capital intensities suited to the German capital abundance. Expansion of Germany and Japan into the machinery causes a terms of trade deterioration for Sweden as a net exporter of machinery. Expansion of Asia and Southern Europe into apparel and textiles cause a terms of trade improvement.

In this model, the existence of forest products causes Swedish deindustrialization in the sense that an increase in forest resource reduces absolutely the outputs of the manufactured products (The Rybczynski Theorem) other than paper. Indeed, the greater is the abundance of forest resources the more likely it is that Sweden remains in the relatively low-wage cone including lumber. In contrast, Germany flows quickly through this cone and moves early on into the production of machinery.

\subsection{THE SWEDISH FoREST PRODUCT SECTOR: THE STARVING HYPOTHESIS}

Figure 4.1 fits the facts well, though we have not yet provided much evidence on the product upgrading in the forest product sector that should come with capital accumulation in Sweden. The forest industries may be classified into labor and capital intensive ones. ${ }^{21}$ Labor intensive forest industries include production in saw mills and planing and some manufacturing of wooden fiber tiles. Capital intensive forest industries include industries for mechanical and semi-chemical pulp and paper and carton industries. Over time, value added and employment has increased much faster in the capital intensive sectors than in the labor intensive ones.

One of the central hypotheses of this chapter is that demand for capital in the forest product sectors can starve other manufacturing of capital and can force Sweden into a more labor-intensive mix of outputs. Table 4.1 offers some idea of the impact of the forest product sectors on the availability of capital and labor for the other manufacturing sectors. $^{22}$ In 1988, the capital per employee in Swedish manufacturing was 170 thousand kronors per worker. The paper products sector employed twenty-six per cent of the capital but only seven per cent of the workers. After extracting the capital and labor used in paper and in wood, the capital intensity drops from 170 thousand kronors per worker to 135 thousand kronors per worker. This makes it difficult to support a pharmaceuticals sector

${ }^{21}$ See Ohlsson and Vinell (1987).

22 In comparison with other sectors, the productivity increase in the wood industry has been lower than in most other industries; the only sector that during 1964-89 has had a lower total factor productivity increase than the wood industry is food processing. The productivity increase in pulp and paper is average and comparable with that in most other sectors. 
or a chemicals sector which have capital intensities of 302 and 284 respectively. ${ }^{23}$ The major sectors with capital intensity below 135 are transport equipment (122), non-electrical machinery(108) and electrical machinery (89).

\section{NONTRADED GOODS AND LABOR MARKET DISTORTIONS}

- High wages can be supported by high demand for labor-intensive nontradeables. This demand can come from government, or from net foreign earnings from natural resource products.

- The cost of a minimum wage as a means to redistribute income has been raised by the low rates of physical and human capital accumulation in Sweden and also by increased competition in the markets for Sweden's relatively labor-intensive products.

The preceding discussion has abstracted from two important features of the Swedish economy. The first is nontraded goods, particularly the huge share of the work force that is employed in the government sector. For instance, in 1960 the Swedish non-tradable sector employed $44 \%$ of the total labor force and in $199075 \%$ were employed in sectors protected from international trade. The second neglected feature is institutional wage compression which acts like a high minimum wage. This minimum wage makes it more difficult for Sweden to produce labor-intensive tradeables, and forces workers who might otherwise find jobs in these sectors to look for work in nontradeables or to opt for unemployment.

Institutional wage compression would be a non-issue if Sweden had no reason to produce labor-intensive tradeables. Distinctive abundance in physical and human capital once conveyed upon Sweden a strong international comparative advantage in capital intensive tradeables. This together with a high demand for unskilled workers in

23 This discussion follows the theory which takes as given the capital and labor allocated to manufacturing. Given $\mathrm{K}$ and $\mathrm{L}$, the allocation of employment across sectors must satisfy two conditions. The overall capital-labor ratio is an employment weighted average of the sector capitallabor ratios

$K / L=\Sigma L_{i}(K / L) i ~ \Sigma L i$

and the labor allocated to each sector must exhaust the labor supply.

$\mathbf{L}=\Sigma \mathbf{L}_{i}$

Thus if a substantial amount of labor is allocated to a capital intensive sector, an offsetting amount must be allocated to a labor intensive sector to maintain the first condition.

These conditions in practice are not that confining, but the more important constraint theoretically comes from the choice of factor and goods prices which tends to force a concentration of manufacturing on a small band in the capital-per-worker spectrum. 
nontradeables made wage compression a natural competitive outcome, not something that had to be imposed. Over the last several decades, Sweden failed to maintain its lead in human and physical capital, thus allowing the capital-intensity of Swedish international comparative advantage to drift downward and thereby exposing the Swedish unskilled workers to competition from lower wage foreigners. This has raised the economic costs of wage compression. It is an irony, by the way, that increased investments in human and physical capital that in the long run would lead naturally to income equality probably in the short nun will only occur if the inequality is worse, that is if there is adequate incentive to make the investments.

\subsection{NONTRADED GOODS}

- A high demand for labor-intensive non-traded goods can support a high-wage solution. This demand keeps the price of nontradeables high and shifts resources from tradeables to non-tradeables. On the assumption that non-tradeables are labor intensive, this shift tends to leave tradeables with relatively little labor compared with capital. This higher capital intensity supports a higher wage.

- Government is one important source of demand for nontraded goods. Some simple calculations suggest that government employment has played an important role in maintaining Swedish wages.

- Net external earnings from natural resources also generate demand for nontradeables. Swedish earnings from forest products were partially offset by expenditures on imported petroleum, making the forest resource less capable of supporting a high-wage equilibrium immediately after the oil-price shock, but reduced petroleum expenditures have restored the very favorable Swedish trade balance in natural resource products.

A nontraded sector is added to the $\mathrm{H}-\mathrm{O}$ framework in this section. According to the multi-cone H-O model, Sweden will be able to sustain high wages if the supply of factors to the traded goods sector is suited to the most capital intensive mix of products. If too much labor is supplied relative to capital, then some of the labor has to be absorbed into the production of labor intensive commodities like apparel and some forms of textiles. Workers in these sectors necessarily compete head-to-head with low-paid workers in Southern Europe, Northem Africa and Asia. These labor-intensive sectors can survive international competition only if wages fall to the low levels paid by these foreign producers. If a scarcity of human and physical capital forces Sweden to compete directly against low-wage suppliers, then Swedish wages will be set in the labor markets of Lisbon and Beijing, not in Stockholm.

Communities and countries with enough capital can have high wages for unskilled workers if they concentrate on capital intensive tradeables and absorb unskilled workers 
partly in these skill-intensive sectors and partly in nontradeables. Figure 5.1 illustrates this possibility with two traded goods, machinery and apparel, and one nontraded good, government. Two possible equilibria are depicted, one with low wages and apparel production, the other with high wages and no apparel production. The low-wage equilibrium is associated with the solid line isocost through the vertices of the machinery and apparel unit-value isoquants. This equilibrium occurs when some but not enough of the factor supplies are used in the government sector, leaving, for example, the amount $L$ for the traded goods sector. If the government absorbs more resources, leaving the amount $H$ for the traded goods sector, then not enough labor is available to support apparel production and only machinery is produced. Then the high-wage equilibrium indicated by the dotted unit cost line will occur.

Incidentally, Figure 5.1 is prejudiced in one very serious way. It is drawn on the assumption that extraction of resources into the government sector leaves the remainder more suited to the production of the capital intensive mix of commodities. In fact the work force in government is quite highly educated, and government employment may be starving manufacturing of needed human capital. This could be depicted in Figure 5.1 if the government sector were more capital intensive than the machinery sector, in which case, allocating resources to government shifts manufacturing toward apparel not toward machinery. This can force Sweden into a low-wage equilibrium. Another possibility is that government is intermediate in capital intensity, lying between apparel and machinery. Then government does not fundamentally alter the mix of resources available to the traded goods sector.

Another source of demand for nontradeables is the earnings from the sale of natural resource products. If these earnings are high enough Sweden can afford to import the labor-intensive manufactures and avoid direct competition with the low-wage emerging countries around the globe. The increased bill for petroleum in 1974 that is very evident in Graph 3.12 offsets earnings from forest products, thereby reducing the demand for nontradeables and making high wages more difficult to sustain. But the lowered demand for petroleum in 1988 evident in Graph 3.13 restores the very favorable balance on natural resource trade which makes it again a source of support for high wages.

The model depicted in Figure 5.1 suggests some simple accounting to determine the impact of the resource demands in the nontraded goods and natural resource sectors on Swedish wages. Let $K_{m}$ and $L_{m}$ denote capital and labor used in manufacturing and $K_{n}$ and $L_{n}$ the corresponding factors used in non-traded sectors. If $K_{f}$ and $L_{f}$ are inputs into natural resource sectors like forestry, agriculture, mining and quarrying, and $\mathrm{K}$ and $\mathrm{L}$ are the Swedish totals, then the capital intensity of factors supplied to manufacturing is $K_{m} / L_{m}=(K-$ $\left.\mathrm{K}_{\mathrm{r}}-\mathrm{K}_{\mathrm{n}}\right) /\left(\mathrm{L}-\mathrm{L}_{\mathrm{r}}-\mathrm{L}_{\mathrm{n}}\right)$. The higher is this ratio, the more capital intensive will be the mix of Swedish manufacturing products and the higher is the sustainable level of wages.

By varying the levels of capital and labor in the nontraded goods sectors under different assumptions regarding the behavior of government, this simple formula allows us to compute the capital/labor ratio of the factors remaining for manufacturing.

Swedish capital labor ratios in ISIC sectors 31-39 from 1962 through 1990 are illustrated in Graph 5.1 together with the overall ratio. Graph 5.2 shows the relative shares of value added of the industries from 1962 to 1991 . Food, textiles, minerals and wood 
products have lowered their shares of overall manufacturing production, pulp and paper is relatively unchanged while chemicals and manufacturing of metal products have increased. This is broadly what the $\mathrm{H}-\mathrm{O}$ model predicts.

The capital/abor ratios depicted in Graph 5.1 have three noticeable features: (a) a general upward trend,(b) a relative slide in ISIC 37, Metals, from the most capital intensive sector to a more moderate level (this is the Swedish winning sector!), and (c) a slow slide upward, relatively speaking, of the overall ratio in manufacturing until 1978, when the Swedish mix of output stopped increasing in capital intensity.

Into this figure we have inserted hypothetical values for the capita/labor ratio in manufacturing for three different scenarios differing in the role of the public goods sector as an absorber of labor.

Experiment 1:No growth in employment in non-traded sector after 1980. In the first calculation we fix employment in the non-traded sector and allocate the increase in total labor supply after 1980 totally to manufacturing. Capital allocation is unaffected. This is the extreme "starving" scenario in the sense of reducing the capital/abor ratio in manufacturing by the largest amount.

Experiment 2: Fixed employment levels in non-traded sector, fixed total employment. Next we fix the employment level in the non-traded sector and also total employment at 1980 levels to reflect the extreme but not altogether unrealistic assumption that, absent the expansion of the public sector, these government employees would have opted out of the labor force. (It is often argued that a reason why Sweden is able to keep a leading position in terms of female labor market participation is because of the extended government sector.)

Experiment 3: All additions to capital allocated to manufacturing. In this experiment, we fix also the capital stock of the non-traded sector at the 1980 level and assume that increases in the capital stock are absorbed in the manufacturing sector. The assumptions under (2) continue to hold.

Under experiment 1 depicted in Graph 5.1 the overall capita//abor ratio drops precipitously, falling below the capital intensity in ISIC 33, wood products, and moving in the direction of ISIC 38, metal products, and ISIC 32, apparel and textiles. The implication of this first calculation is that government employment has been a key reason for high wages in Sweden, since, absent that employment, the traded goods manufacturing sector would have had to absorb labor by shifting into labor-intensive sectors which, because of international competition, cannot pay high wages. This product down-grading effect is less severe but still noticeable under the second experiment which holds the employment levels fixed. The capita//abor ratio in manufacturing noticeably improves if all additions to capital are allocated to manufacturing, experiment $3 .{ }^{24}$

${ }^{24}$ The assumptions in this experiment implies, though that the size of the Swedish labor force would fall by 350000 people. 


\subsection{LABOR MARKET DISTORTION: WAGE COMPRESSION FROM ABOVE}

- Labor market institutions that attempt artificially to lower wages of high-skilled workers put out of business the labor intensive tradeables sectors, thus shift the output mix of manufacturing toward products that use physical capital (but not skills) intensively.

- The reduction in the rate of return to skills causes an even larger reduction in the rate of return to physical capital, provided that the total capital requirements in the skill-intensive sector are higher than any other sectors.

- Some of the workers released from the labor-intensive tradeables sector find jobs, but others are unemployed. The level of unemployment is a decreasing function of the supplies of human and physical capital. Supplies of physical capital are choked off because the return to human capital is relatively high. Additional supplies of human capital are also choked off since the return to skills is lower by design.

Income inequality can be fought from below with minimum wages or from above with maximum wages. In this subsection, we consider the effects of a maximum wage, which we take to be a limit on the rate of return to human capital. The differences between the effects of a minimum and a maximum wage are minor.

Figure 5.2 has the unit value isoquants for three traded goods: chemicals, machinery and textiles. The vertical axis refers to both human and physical capital, which we assume initially to have the same rates of return. For the sake of argument, we assume also that the chemicals sector uses only human capital, and machinery and textiles use only physical capital.

Now suppose that centralized wage bargaining attempts to eliminate inequality by lowering the return on human skill to the level $r(S k i l l)$ in the figure. This lowered price for human capital makes the chemicals sector highly profitable and it attempts to expand by employing both skilled and unskilled workers. Since all the skills are already employed in the chemicals sector there is no possibility for expansion. The higher profits in the chemicals sector are eliminated only if the wage rate for unskilled workers is bid up to the level indicated by wage(FINAL). This higher wage for raw labor must be offset by cheaper physical capital costs if the physical capital is to be employed. The return on physical capital must accordingly fall to the level r(Cap), low enough to keep the Machinery sector in operation. This reduction in the retum to physical capital exceeds the forced reduction in the rate of return to human capital.

Operation of only the chemicals sector and the machinery sector can employ all the physical and human capital but cannot generate enough demand for unskilled workers to keep them all employed. A transfer of capital from textiles to machinery does allow an expansion of employment there, but not enough to offset the loss of textiles jobs. The exact 
amount of unemployment depends on the supplies of physical and human capital. If $(\mathrm{H} / \mathrm{L})_{\text {chem }}$ is the human capital per worker in the chemicals sector and if $\mathrm{H}$ is the total amount of human capital, then the labor used in the chemicals sector is $\mathrm{L}_{\text {chem }}=H /(H / L)_{\text {chom }}$. If $(K / L)_{\text {mach }}$ is the physical capital per worker in machinery and $K$ is the total physical capital, then the labor used in the machinery sector is $\mathrm{L}_{\text {mach }}=\mathrm{K} /(\mathrm{K} / \mathrm{L})_{\text {mach. }}$. Thus the level of unemployment is $U=L-H /(H / L)_{\text {chem }}-K /(K / L)_{\text {mech, }}$ and the unemployment rate is $U / L=1$ $(\mathrm{H} / \mathrm{L}) /(\mathrm{H} / \mathrm{L})_{\text {chem }}-(\mathrm{K} / \mathrm{L}) /(\mathrm{K} / \mathrm{L})_{\text {mech. }}$. This unemployment rate can be lowered only by investments in human and physical capital. But investments in physical capital are entirely choked off because of its inferior return, and investments in human capital are discouraged by the forced reduction in its rate of return.

\section{Economic Costs of a Minimum Wage}

This figures does not allow a precise statement regarding the economic costs of wage compression since that would depend in fairly complicated ways on supply and demand elasticities that would determine the allocation of factors among the tradable sectors, the nontradeable sectors and unemployment. What can be said generally is that the greater the distortion the greater the cost. The distortion is partly a function of the difference between the undistorted and distorted compensation levels, and partly a function of the intersectoral resource transfers that are necessary to support the distorted equilibrium. These are fundamentally driven by three phenomena: technology, international competition (price determination), and Swedish physical and human capital accumulation. 25

\subsection{FINAL REMARKS: A HECKSCHER-OHLIN FORECAST FOR SWEDEN.}

We have presented substantial evidence of Heckscher-Ohlin Crowding (closer competitors for Sweden) and Heckscher-Ohlin Starving/Enriching (Forest products and the public sector affecting the physical and human capital available for tradable manufactures). We have employed a conceptual framework in which Swedish wages and Swedish compensation for skills are determined in the global product markets. According to this theory, both crowding and starving can have serious consequences, lowering wages for unskilled workers and raising the premium for skills. The effects of crowding and starving

${ }^{25}$ Until the first half of the 1980's wage bargaining took place at the centralized level between LO and SAF. The wage compression that is a natural outcome of centralized bargaining operates essentially like a minimum wage, trading increases in retums for unskilled labor for reduced returns for human capital. This institution was abandoned during the first half of the 1980's and since then wage differences have increased. If this theory is correct, with this reversal will come initially a shift in resources out of nontraded goods sector and into relatively labor intensive manufacturing, say textiles. Over time, the increased incentive for human capital accumulation can be expected to produce a shift in the manufacturing product mix in favor of the more skill-intensive and capital-intensive sectors, machinery and chemicals. 
on wages of the unskilled can be offset by public sector employment and by high rates of capital formation, particularly, in our view, investments in human capital.

This framework can be used for some speculative remarks concerning other aspects of Sweden's future economic development. Internationally, Sweden today faces two major changes. One is further globalization that would come from membership in the European Union, or from an EEA agreement. These steps toward integration hopefully will not be offset by the erection of new tariff and nontariff barriers elsewhere. The second is the challenge of the previously centrally planned economies (PCPE:s) entering the global marketplace. The emergence of such large countries in the proximity of Sweden could over time fundamentally alter Sweden's external economic opportunities.

Concerning globalization, Sweden may have little to fear as the Swedish economy for a long time has been free trade oriented. The removal of the remaining trade barriers is not likely to expose Sweden to any major changes in the manufacturing sectors. Swedish manufacturing firms are to a large extent multinationals or, if national, have a long-standing experience of foreign competition in domestic markets. But more important changes might occur in other parts of the economy. Service sectors, such as legal and financial services, which today face mostly local competition may find themselves increasingly exposed to international competition. This might imply a great deal of structural change in the Swedish economy as, today, a large share of the work force produces services in the non-tradable sector.

The second change, the challenge of the PCPE:s like Russia, the Baltic states, Poland and other countries, is likely to have more of an impact on Swedish industries. This challenge can be captured in Figure 2.3 which has been used to depict increased competition from three sides: from Germany, in sectors intensive in human capital, from Japan, in sectors intensive in physical capital and from Asia, in labor-intensive sectors. The emergence of the PCPE:s in the world market can be added to Figure 2.3. Where they are placed initially depends on the extent at which these physical capital poor countries can put their human capital to productive work.

Two possibilities are depicted in Figure 6.1, differing in terms of the initial level of PCPE human capital. The abundant human capital point, PCPE1, and the associated path of capital accumulation, has the PCPE's relatively little involved in either apparel or textile production. This path is likely to be associated with downward price pressures on the human capital intensive products, which in turn raises the real wage of raw labor and lowers the skill premium. In response to these factor price changes, it is appropriate for Sweden to shift its investment mix away from human capital and toward physical capital, which we depict as path 1 emanating from the Swedish point in Figure 6.1.

In the second case, represented by the initial point PCPE2, it is assumed that those educated in the planned economies cannot be used efficiently in the market economies. The initial product mix is more labor intensive, and the growth path takes the PCPE's through apparel and textiles, never including much of the human-capital intensive chemicals production. In this case, it is even more urgent that Sweden quickly abandons her most labor intensive sectors and the falling prices of these goods will encourage Swedish producers to do so. The falling price of apparel will mean mostly an improved terms of 
trade, since apparel is hardly at all produced in Sweden. But with further capital accumulation the PCPE's will enter into markets that are more important for Swedish manufacturers, products which are labeled "textiles" in Figure 6.1 that use more physical capital but little human capital. Declining prices for these goods will lower the wage rate of raw labor and increase the skill premium, encouraging a shift in the Swedish investment composition in favor of human capital, denoted by arrow 2 in Figure 6.1.

In both cases, Sweden is likely initially to enjoy terms of trade improvements but more so in the second case than in the first. As these countries have a long way to go in terms of catching up in real capital formation these terms of trade improvements might be considerable and taper off some time in the future when the PCPE:s enters the chemicalsmachinery-textiles cone.

Though both paths offer initial terms of trade improvements, the paths have very different implications for the optimal investment mix and the effects of wage compression. The first path, with human capital abundant PCPE's, is compatible with Swedish low rates of investment in human capital and a low premium for skills. On the other hand, if the PCPE's are scarce in human skills, the international marketplace will dictate a higher skill premium thus creating an opportunity which should be seized by much higher rates of investments in human capital.

The major benefits from the emergence of the PCPE's will accrue to those countries with capital in place when the process hits full stride. Now is the time to make the investment decisions in preparation for these market opportunities. We conjecture that the effective PCPE human capital stock is small, and the PCPE2 path is the more likely. The appropriate response would then be to increase the Swedish investment rates in human capital, in education and training. 


\section{SELECTED REFERENCES}

Barro, Robert (1991), "Economic Growth in a Cross Section of Countries," Quarterly Journal of Economics, 106, 407-443.

Davis, Stephen J. (1992), "Cross-Country Patterns of Change in Relative Wages," in 1992 Macroeconomics Annual, eds. Olivier Blanchard and Stanley Fischer, New York: National Bureau of Economic Research.

Edin, Per Anders and Holmlund, Bertil (1993), "Avkastning och efterfrågan på högre utbildning," Ekonomisk debatt, vol. 21 (1), 31-45.

Eklund, KJas (1992):"Drivkrafter och omvandlingstryck för höjd produktivitet, " Ekonomisk debatt, Vol. 20 (1), 5-14.

DeLong, J. Bradford and Summers, Lawrence H. (1991), "Equipment Investment and Economic Growth," Quarterly Joumal of Economics, CVI, 445-502.

Ethier, Wilfred (1984), "Higher Dimensional Issues in Trade Theory," in Jones, Ronald and Peter B. Kenen, Handbook of International Economics. Volume I, Amsterdam: North Holland Publishing Co. Chapter 3.,

Hansson, Bengt (1991):"Measuring and Modeling Technical Change," Department of Economics, Uppsala University, unpublished dissertation, Uppsala.

Hansson, Pär (1993), "Changing Comparative Advantage of Sweden and in OECD during the 1970's and 80's, "Trade Union Institute for Economic Research.

Hjalmarsson, Lennart and Walfridsson,Bo(1991): "Kapitalbildning kapitalutnyttjande och produktivitet", Norstedts tryckeri, Stockholm

Hjalmarsson, Lennart and Walfridsson, Bo (1992):"Den fysiska kapitalbildningens betydelse för produktiviteten i svensk tillverkningsindustri, " Ekonomisk debatt, Vol 20.(1), 15-26.

Hulten, Charles, R. and Wykoff, F.C. (1981):"The Measurement of Economic Depreciation," in Hualten (ed.), "Depreciation. Inflation and the Taxation of Income from Capital", Washington D.C.:The Urban Institute Press, 81-125.

Lawrence, Robert Z. and Slaughter, Matthew J. (1993), "Trade and US Wages: Great Sucking Sound or Small Hiccup," Brookings Papers on Economic Activity...

Leamer, Edward E. (1984), Sources of International Comparative Advantage: Theory and Evidence, Cambridge, Mass.: The M.I.T. Press.

Leamer, Edward E. (1987), "Cross Section Estimation of the Effects of Trade Barriers," in Empirical Methods for International Trade, ed. Robert Feenstra, Cambridge, Mass.: The M.I.T. Press, 52-82.

Leamer, Edward E. (1987), "Paths of Development in the Three-Factor N-Good General Equilibrium Model," Joumal of Political Economy, 961-999.

Leamer, Edward E. (1991), "Wage Effects of a U.S.-Mexican Free Trade Agreement," in Peter Garber, ed., The Mexico - U.S. Free Trade Agreement, Cambridge: M.I.T. Press, 1994, 57-128.

Leamer, Edward E. (1993), "U.S. Manufacturing and an Emerging Mexico," North American Journal of Economics and Finance, Vol. 4, No. 1, Spring 1993, 51-89.

Leamer, Edward E. and Bowen, H. P. (1981), "Cross-Section Tests of the Heckscher-Ohlin Theorem: Comment," American Economic Review, 1040-1043. 
Lundberg, Lars and Wiker, Per (1993), "Human Capital, Skilled Labor and International Specialization in OECD Countries," Trade Union Institute for Economic Research, Stockholm.

Mankiw, N.G., Romer, D. and Weil, D.N. (1992), "A Contribution to the Empirics of Economic Growth," Quarterly Joumal of Economics, CVII, 407-437.

Murphy, Kevin M., Shleifer, Andrei and Vishny, Robert W. (1991), "The Allocation of Talent: Implications for Growth," Quarterly Journal of Economics, CVI, 503-530.

Ohlsson, Lennart and Vinell, Lars (1987): "Tillväxtens drivkrafter:En studie av industriers framtidsvillkor," Industriforbundets forlag, Stockholm.

Ravenga, Ana L. (1992), "Exporting Jobs? The Impact of Import Competition on Employment and Wages in U.S. Manufacturing," Ouarterly Journal of Economics, 107, 255-282.

SOU 1990:14:Lanotidsutredningen 1990, Stockholm, Allmänna forlaget.

SOU 1991:82: "Drivkrafter för produktivitet och vallstånd, " Stockholm, Almänna förlaget.

Solow, Robert (1956), "A Contribution to the Theory of Economic Growth, "Quarterly Journal of Economics, 70, 65-94.

Solow, Robert (1957), "Technical Change and the Aggregate Production Function," The Review of Economics and Statistics, 39, 312-320.

Song, Ligang (1993), "Sources of International Comparative Advantage: Further Evidence," Unpublished Ph.D. dissertation, Australian National University.

Summers, Robert and Heston, Alan (1991), "The Penn World Table (Mark 5): An Expanded Set of International Comparisons, 1950-1988," Quarterly Journal of Economics, CVI, 327-368.

Thomberg, Christopher (1993), "A Factor Analysis of the Swedish Economy," UCLA, Anderson Graduate School of Management.

.Wolff, Edward N. and Gittleman, Maury(1993): "The Role of Education in Productivity Convergence: Does Higher Education Matter?, in Szinnai, van Ark and Pilat: "Explaining Economic Growth", Elsevier Science Publishers B.V. 


\section{DATA SOURCES}

1. Euromonitor, European Marketing Data and Statistics, 1993. London: Euromonitor Plc, 1993

2. Euromonitor, International Marketing Data and Statistics, 1993. London: Euromonitor PIc, _1993

3. Food and Agricultural Organization of the United Nations, FAO Yearbook Production, 1991. Rome: FAO, 1992

4. Heston, A. and Summers, H. "A New Set of International Comparisons of Real Product and Prices for 130 Countries 1950-1985", Review of Income and Wealth March, 1988 Series 34 No. 1

5. Heston, A. and Summers, H. Supplementary data on "A New Set of International Comparisons of Real Product and prices" 1950-1988

6. Hulten, C. R and Wykoff, F. C., "The Measurement of Economic Depreciation" in Depreciation. Inflation, and the Taxation of Income from Capital edited by Charles Hulten The Utban Institute Press: Washington, D.C. _ 1981

7. International Labour Office, Year Book of Labour Statistics, various years. Geneva: ILO, various years

8. International Monetary Fund, International Financial Statistics Yearbook, 1992. Washington D.C.: MF, _1992

9. Office of Business Analysis, National Trade Data Bank (CD Rom), 1992. Washington: U.S. Department of Commerce, _1992

10. Organisation for Economic Co-operation and Development, Education in OECD Countries, 1988. Paris: OECD, 1989

11. Organisation for Economic Co-operation and Development, Public Educational Expenditures. Costs and Financing: an Analysis of Trends, 1970-1988. Paris: OECD, 1992

12. Statistics Directorate, National Accounts Statistics, 1956-1965, Paris:OECD, 1966

13. Statistics Directorate, National Accounts of OECD Countries, 1961-1978, Paris, OECD, 1978

14. Statistics Directorate, Historical Statistics, 1960-1984, Paris: OECD 1986.

15. Statistics Directorate, Historical Statistics, 1960-1990:Paris: OECD, 1992

16. Statistics Directorate, Labour Force Statistics, 1956-1966, Paris:OECD 1968.

17. Statistics Directorate, Labour Force Statistics, 1969-1989, Paris:OECD, 1991

18. Statistics Directorate, National Accounts Detailed Tables, 1978-1990. Paris: OECD, _1992

19. Statistics Directorate, National Accounts Main Aggregates, 1960-1991. Paris: OECD, 1992

20. Statistics Directorate, National Accounts Detailed Tables, 1979-1991. Paris: OECD, 1993

21. Statistiska Cenatralbyråns Tidsseriedatabas, Industristatistiken.

22. Statistiska meddelanden, Prisindex i producent- och importled under 1992, P 10 SM 9302.

23. Statistiska meddelanden, Hogskolan. Grundutbildning: Registrerade studerande hostterminerna 19771992, U 20 SM 9303.

24. United Nations Education Scientific and Cultural Organization, Statistical Yearbook, various years. Paris: UNESCO, various years 


\section{List of Figures}

2.1 Unit Value Isoquants and Isocosts: Hypothetical Initial post-war Period

2.2 Unit Value Isoquants and Isocosts: With Large European Capital Increases

2.3 Cones of Diversification: Physical Capital, Human Capital, and Labor

4.1 Cones of Diversification: Forests, Capital, and Labor

5.1 High-Wage and Low-Wage Equilibria: Use of Factors in Government

5.2 Effects of Wage Compression

6.1 Cones of Diversification: Labor, Human Capital and Physical Capital. 


\section{Unit Value Isoquants and Isocosts Hypothetical Initial Post-War Period}

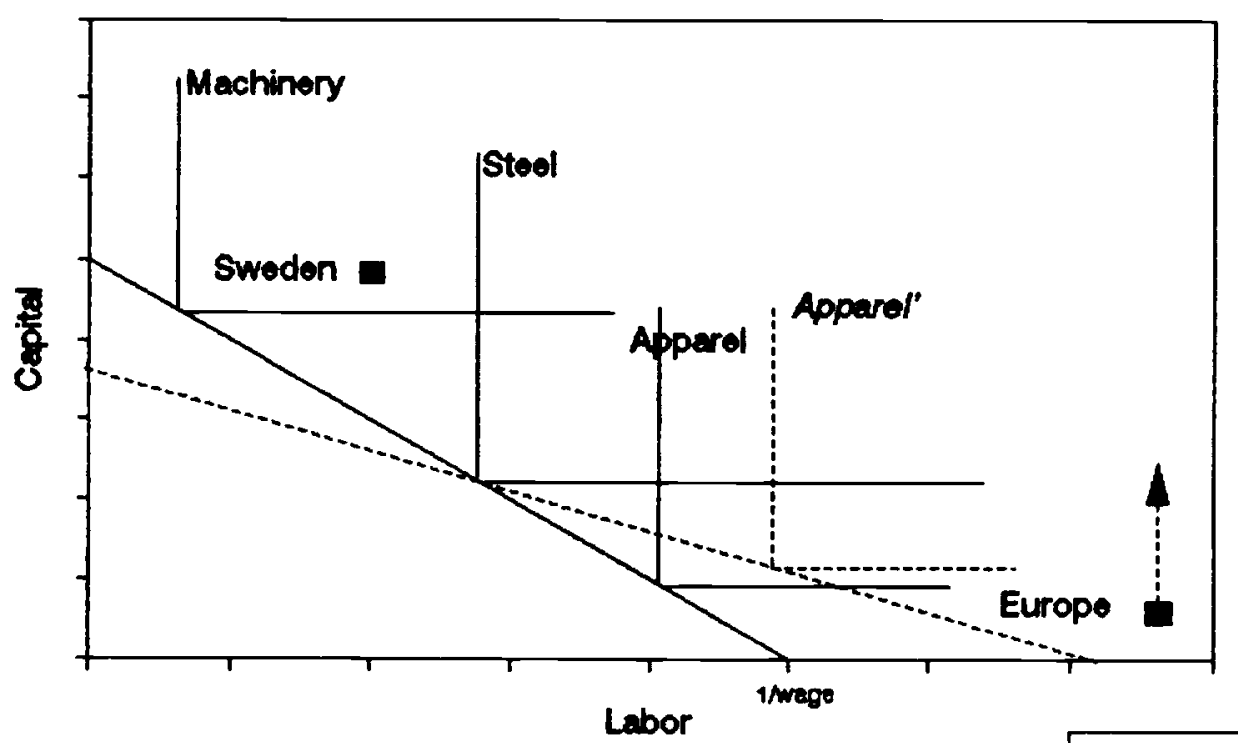

FIGURE 21

\section{Unit Value Isoquants and Isocosts With Large European Capital Increases}

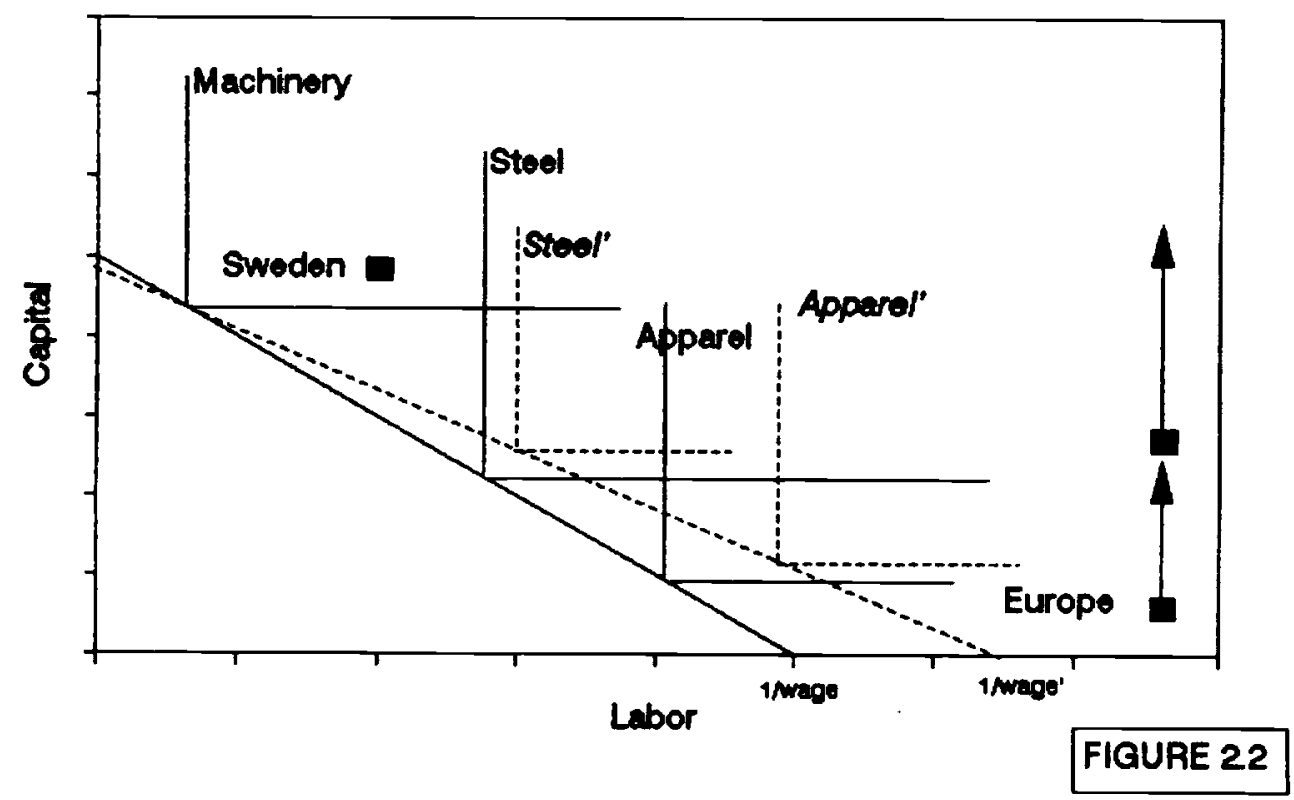




\section{Cones of Diversification}

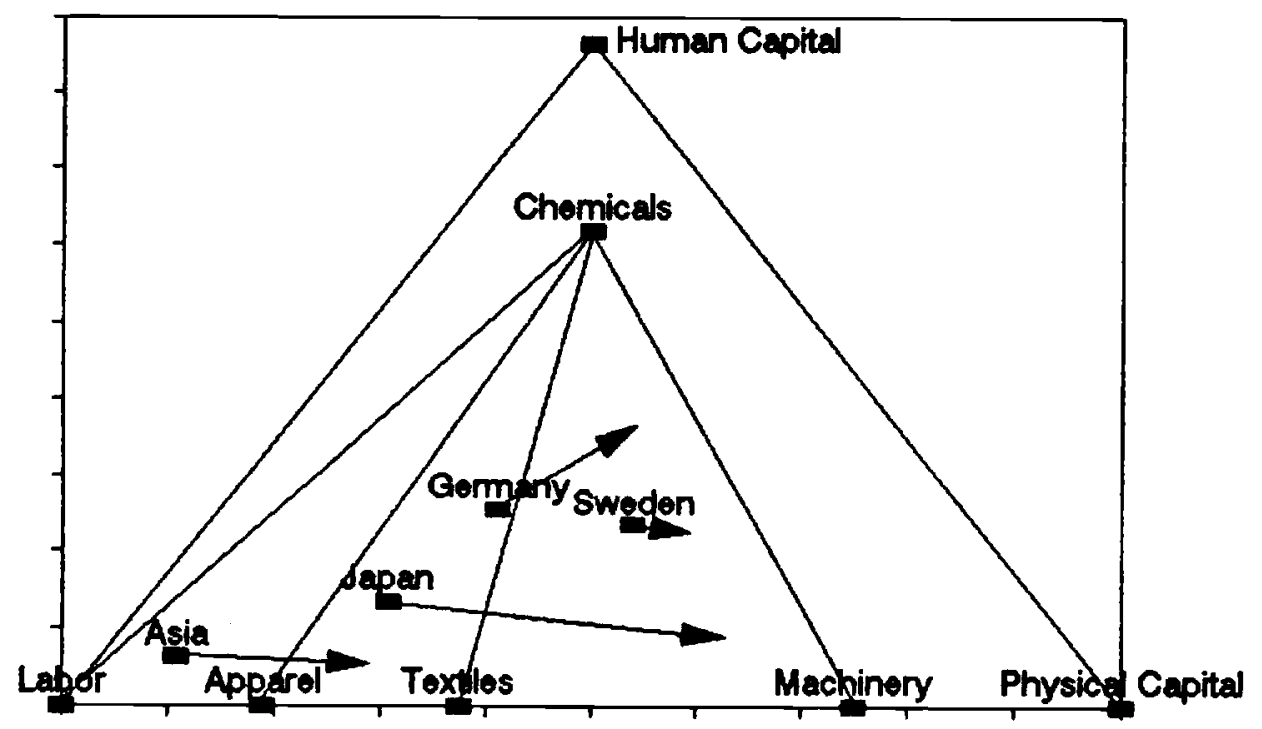

Handicrafts

\section{FIGURE 23}

\section{Cones of Diversification}

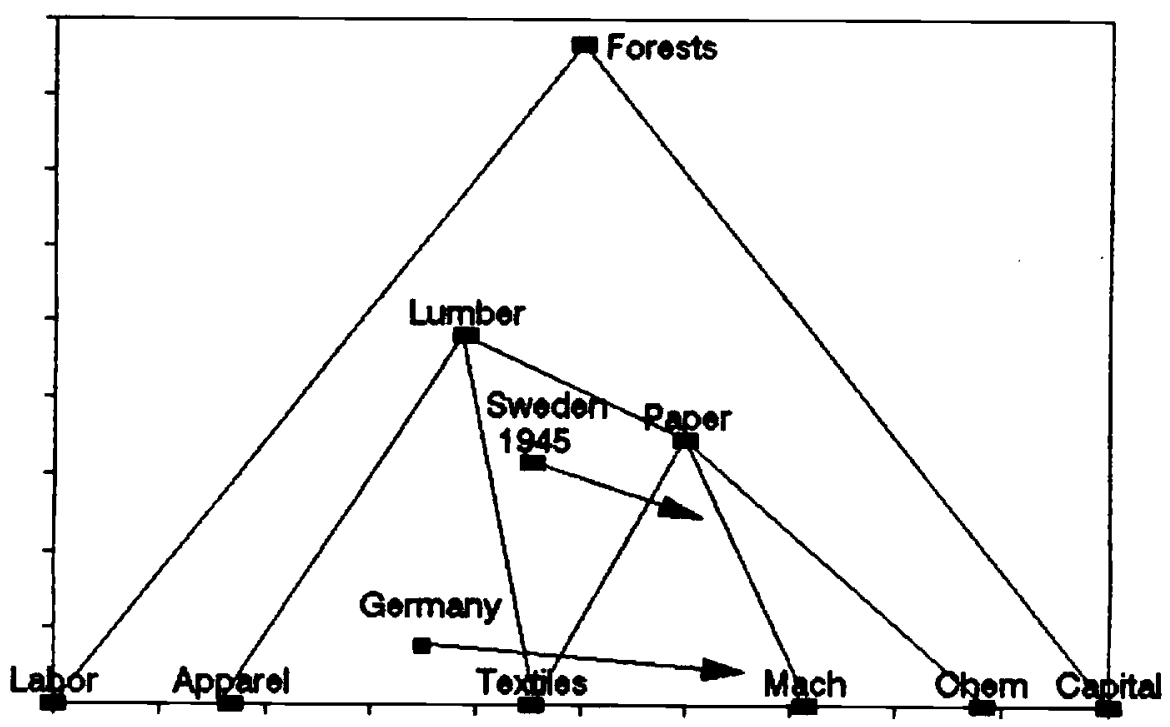

FIGURE 4.1 


\section{High-wage and Low-wage Equilibria Use of Factors in Government}

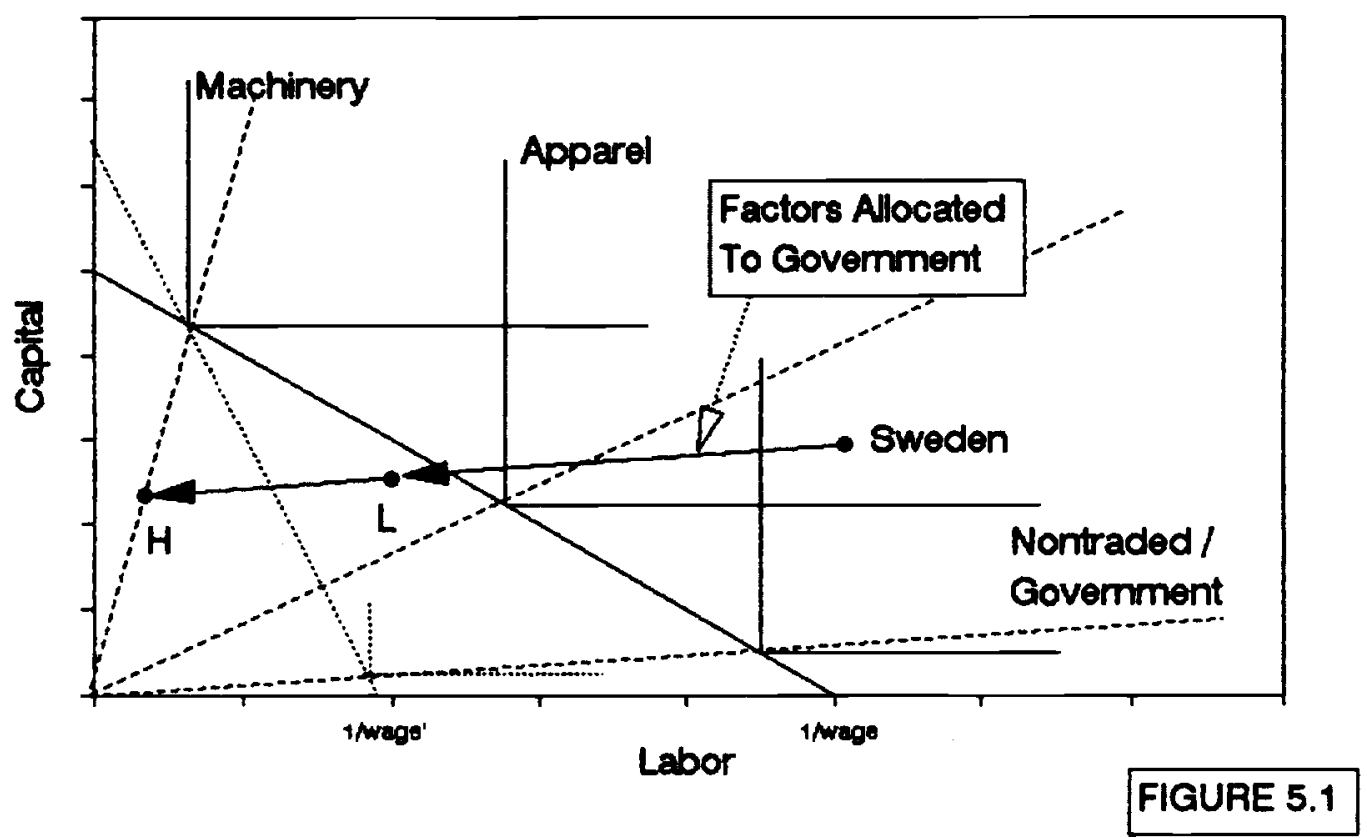

Effects of Wage Compression Maximum Skill Premium: r(skill)

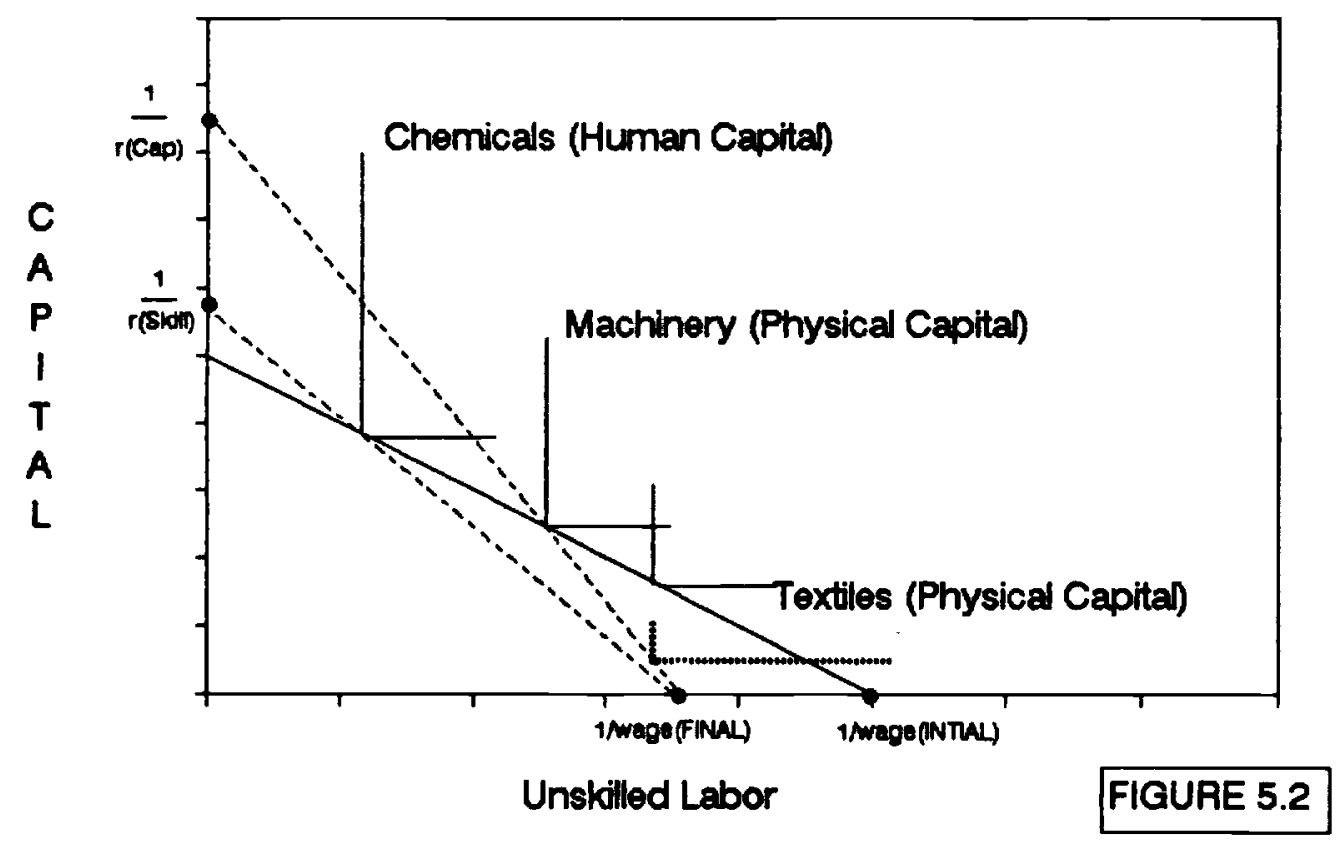




\section{Cones of Diversification}
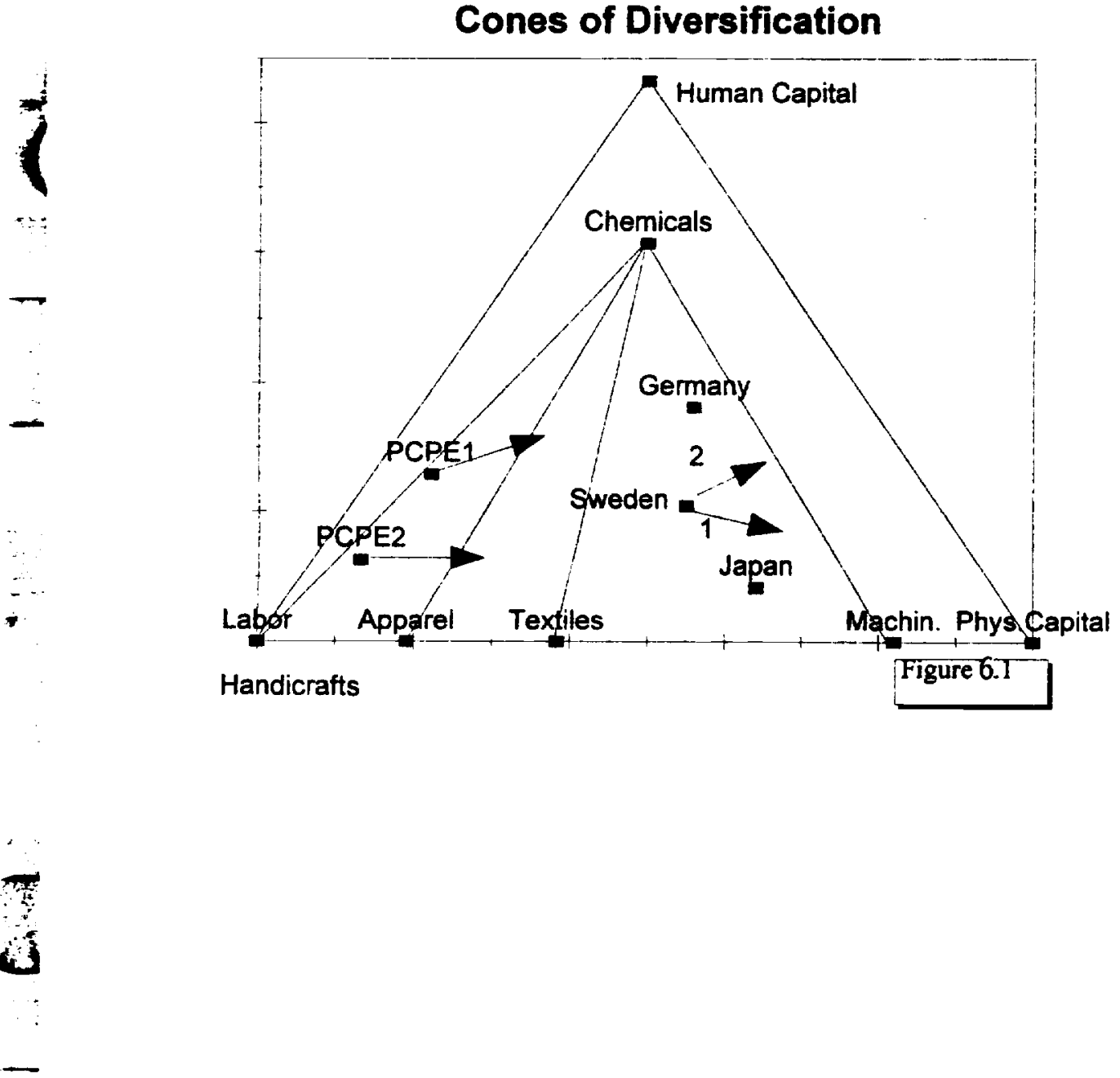


\section{LIST OF TABLES}

3.1 Regressions of Growth in GDP per worker on Growth in Capital per Worker

3.2 Components of Ten Aggregates

3.3 External Performance Swedish Industry Relative to Swedish Consumption.

3.4 External Performance of Swedish Industry

3.5 Swedish Revealed Comparative Advantage: Relative Shares of OECD Output

3.6 OECD Manufacturing Value Added Shares

3.7 Heckscher-Ohlin Trade as a Percent of Total Trade

4.1 Allocation of Capital and Labor in Manufacturing 
Table 3.1

Regressions of Growth in GDP per worker on Growth in Capital per Worker

\begin{tabular}{|rrrrrr|}
\hline Intercept & $\begin{array}{r}\text { Physical } \\
\text { Capital } \\
(1)\end{array}$ & $\begin{array}{r}\text { Human } \\
\text { Capital } \\
(2)\end{array}$ & $\begin{array}{r}\text { Human } \\
\text { Capital } \\
(3)\end{array}$ & $\begin{array}{r}\text { Total } \\
\text { Capital } \\
(4)\end{array}$ & R-SQ \\
\hline 0.0514 & 0.547 & & & & 0.69 \\
$(3.68)$ & $(7.01)$ & & & & \\
\hline 0.091 & & 0.13 & & & 0.04 \\
$(2.68)$ & & $(.89)$ & & & \\
\hline 0.0663 & & & 0.305 & & 0.23 \\
$(2.56)$ & & & $(2.54)$ & & \\
\hline 0.0226 & & & & 0.629 & 0.54 \\
$(1.02)$ & & & & $(5.07)$ & \\
\hline
\end{tabular}

\section{NOTES}

Definitions of Variables

(1) Physical Capital Per non-Government Worker

(2) Human Capital per Capita

(3) Human Capital per Worker

(4) Human + Physical Capital per Worker

Data Base

Three six-year time periods, 1970-'76, 76--82,'82-'88

Countries: Can, Ita, Ger, Net, Ost, Spa, Swi, UK

Exchange Rate Treatment

GDP: Local deflators, 1985 PPP-adjusted exchange rate

Human Capital: Locally accumulated, local deflators, separate current and capital stocks, 1985 PPP-adjusted exchange rate

Physical Capital: Locally accumulated, local deflators, 1985 PPP-adjusted exchange rate 
Table 3.2 Components of Ten Aggregates

SITC

1. PETROLEUM (PETRO)

PETROLEUM AND DERIV.

\section{RAW MATERIALS (MAT)}

CRD FERT \& MINR

METALLIFER ORES

COAL, COKE

GAS, NAT \& MANF

ELECTR CURRENT

NON-FERROUS METAL

3. FOREST PRODUCTS (FOR) LUMBER, WOOD \& CORK PULP \& WASTE PAPER CORK AND WOOD MANF PAPER

4. TROPICAL AGRICULT. (TROP) VEGETABLES

SUGAR

COFFEE

BEVERAGES

CRUDE RUBBER

5. ANIMAL PRODUCTS

LIVE ANL

MEAT

DAILY PDCTS

FISH

HIDES, SKINS

CRD ANL \& VEG

ANL \& VEG OIL PROC

ANLS N.E.S.

6. CEREALS, ETC (CER)

\section{CEREALS}

FEEDING STUFF

MISCELLANEOUS

TOBACCO

OIL SEEDS

TEXT. FIBER

ANL OIL \& FAT

FIXED VEG OILS

33
7
8
32
35
68

SITC

7. LABOR INTENSIVE (LAB)

MON-METAL MINERL 66

FURNITURE 82

TRAVL GOOD, HNDBAG 83

ART APPAREL $\quad 84$

FOOTWEAR $\quad 85$

MISC MANF ART 89

POSTAL PACK NO CLASS 91

SPECIAL TRANS NO CLAS

COINS NONGOLD 96

8. CAPITAL INTENSIVE (CAP)

$\begin{array}{ll}\text { LEATHER } & 61 \\ \text { RUBBER } & 62 \\ \text { TEXTILE YARN, FABAIC } & 65 \\ \text { IRON \& STEEL } & 67 \\ \text { MANF METAL N.E.S. } & 69 \\ \text { SANITARY } & 81\end{array}$

5

9. MACHINERY (MACH) POWER GENERATING 71

MACH SPECIALIZED $\quad 72$

METALWRKNG MACH 73

GNAAL INDST MACH $\quad \mathbf{7 4}$

OFFCMACH\&DTAPROC $\quad 75$

TELECOMM \& SOUND $\quad 76$

ELECTRICAL MACH 77

ROAD VEHICL 78

OTHR TAANSP VEHI $\quad 79$

PROF \& SCIENT. INSTA $\quad 87$

PHOTO APPARAT 88

FIREARMS, AMMUNITION 95

10. CHEMICALS (CHEM)

ORGANIC CHEM 51

INORG CHEM 52

DYEING, TANN MAT

MEDICINE PHAR PDCT 54

ESSEN \& PERFUM 55

FERTILIZER MANF 56

EXPLOSIVE \& PYROTECH $\quad 57$

ARTIF RESINES \& PLAST $\quad 58$

CHEM MAT N.E.S. $\quad 59$ 


\begin{tabular}{|c|c|c|c|c|c|c|c|c|c|c|c|c|c|c|c|c|c|c|c|}
\hline \multirow[b]{2}{*}{ ISAC } & \multirow[b]{2}{*}{ Cormodlly } & \multicolumn{5}{|c|}{ Exporterconoumpition } & \multicolumn{5}{|c|}{ importurconoumption } & \multicolumn{5}{|c|}{ (Exporta-mporta)/Conoumplion } & \multicolumn{3}{|c|}{ 1970- 1000 Chenge } \\
\hline & & 1970 & 1975 & 1000 & 1005 & 1000 & 1970 & 1973 & 1000 & ten & 1000 & 1070 & 1975 & 1000 & 1006 & 1000 & $x / c$ & $M / C$ & $(x-M) / C$ \\
\hline \multicolumn{20}{|c|}{ 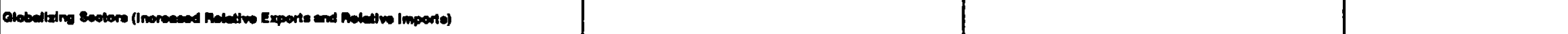 } \\
\hline \multicolumn{20}{|c|}{ 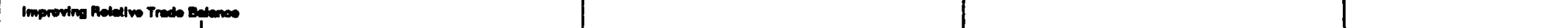 } \\
\hline 3410 & Puip, peper nec & $\infty .2 \%$ & $100.4 \%$ & $115.0 \%$ & $148.3 \times$ & 200.2 & 31.7\% & $58.5 \%$ & $58.7 \%$ & $01.0 \%$ & 10. & $28.5 \%$ & $47.8 \%$ & $50.3 \%$ & $87.3 \%$ & $133.6 \times$ & $120.0 \times$ & $23.9 \%$ & 108. \\
\hline 3310 & Wood, cork nec & $21.4 \%$ & $24.5 \%$ & $30.5 \%$ & $68.6 \%$ & 117. & $12.3 \%$ & $15.8 \%$ & $20.0 \%$ & $22.2 \%$ & & $9.1 \%$ & $8.8 \%$ & $15.6 \%$ & $40.0 x$ & $74.3 \times$ & $\infty 6.2 m$ & $31.0 \%$ & \\
\hline 3522 & Drugs a medicines & $21.1 \%$ & $27.0 \%$ & $45.1 \%$ & $55.0 \%$ & $\infty 5.0 \times$ & 43.96 & $48.3 \%$ & $46.0 \%$ & $40.1 \%$ & 57 & $-22.6 \%$ & $-21.3 \%$ & $-2.0 \%$ & $5.6 \%$ & $30.6 \times$ & $74.8 \%$ & $13.2 \%$ & 01. \\
\hline 3001 & Prod. \& Scientific & $41,4 \%$ & 65.6\% & $\infty .0 \%$ & $100.0 x$ & $80.3 \times$ & $78.0 \%$ & $81.1 \%$ & $101.1 \%$ & $101.7 \times$ & $\pi$ & $30.6 \%$ & $-25.6 x$ & $-14.1 \%$ & $-1,1 \times$ & $0.0 \times$ & $40.0 \%$ & $1.3 \%$ & \\
\hline 3520 & Chemicels nec & 2000 & $42.1 \%$ & $48.3 \%$ & $54.5 \%$ & 73.79 & s1.0x & $50.5 \%$ & $50.4 \%$ & $55.0 \%$ & & $-20.1 \%$ & $-17.4 \%$ & $-2.1 \%$ & $-0.5 x$ & $11.4 \times$ & $46.7 \%$ & $11.3 \%$ & \\
\hline 3020 & Metel, wooctworking & $70.5 \%$ & $71.0 \%$ & $87.7 \%$ & $125.7 \%$ & $105.00 \times$ & 72.84 & $70.0 \%$ & $00.0 \%$ & $01.4 \%$ & 120 & $5.7 x$ & $1.0 \%$ & $23.6 \%$ & $34.3 x$ & 41.5\% & $80.0 \%$ & $50.7 \%$ & \\
\hline 3201 & Tannerie & $87.0 \%$ & $\infty .4 \%$ & $100.4 \%$ & $146.7 \%$ & 02,0 & $07.1 \%$ & $0.4 \%$ & $92.0 \%$ & $\$ 0.1 \%$ & $\pi$ & $-0.5 \times$ & $2.0 \%$ & $8.4 \%$ & $53.6 x$ & $14.1 \times$ & $34.5 \%$ & $10.6 \%$ & \\
\hline 3513 & Synthethic revins & $24.0 x$ & $30.0 \%$ & $40.7 x$ & $47.5 \%$ & $50.2 x$ & 02.46 & $50.2 \%$ & $04.0 \%$ & $\infty .1 \%$ & a & $37.4 \%$ & $-28.3 x$ & $-23.3 \%$ & $-21.7 \%$ & $-18.3 \times d$ & 20.24 & $6.1 \times$ & 10. \\
\hline 3720 & Non-ferrous matals & $21.00 \%$ & $22.6 \%$ & $30.7 x$ & $43.3 \%$ & $40.3 \times$ & $43.5 \%$ & $49.4 \%$ & $45.7 \%$ & $46.3 x$ & & $-22.5 \%$ & $-20.5 \%$ & $-7.1 \%$ & $-3.0 \%$ & $-0.2 \times 1$ & 22.34 & $9.0 \%$ & \\
\hline 3020 & Machinery nec & $4.6 n$ & $52.5 \%$ & $02.5 \%$ & $\infty .6 \%$ & e3. & $30.2 \%$ & $41.4 \%$ & $55.7 x$ & $58.3 \%$ & & $11.7 x$ & $11.1 \%$ & $20.0 x$ & $28.5 x$ & $24.5 \times$ & $30.3 \%$ & $25.7 \%$ & 12.6 \\
\hline 3000 & Pleatices nec & $11.0 \times$ & $17.6 \%$ & $21.1 \%$ & $28.1 \%$ & 30 & $30.7 \%$ & $31.1 \%$ & $35.6 \%$ & $30.0 \%$ & & $-18.7 \%$ & $-13.5 \%$ & $-14.7 x$ & $-10.7 x$ & $-7.0 \times$ & 10.1\% & $7.0 x$ & 11. \\
\hline 3110 & Chocolate, augar c & 6.04 & $12.4 \%$ & $10.4 \%$ & $22.7 \times$ & $27.2 \times$ & $20.2 \%$ & $20.1 \%$ & $20.2 \%$ & 20.5\% & $\mathbf{3 0 . 5}$ & $-13.5 \%$ & $-10.7 \%$ & $-11.0 \%$ & $-0.0 \%$ & $-3.3 \times$ & $20.0 \%$ & $10.3 \%$ & 10.8 \\
\hline $\mathbf{3 6 1 1}$ & Industrial chemicalde & $20.3 x$ & $23.7 x$ & $20.3 \%$ & $39.7 x$ & $30.7 x$ & 50.00 & $40.0 \%$ & $64.0 \%$ & $67.5 \%$ & $\infty .7 \times$ & $31.4 \%$ & $-25.0 \%$ & $-27.7 \%$ & $-27.6 \%$ & $-22.0 x$ & $10.4 \%$ & $1.0 x$ & \\
\hline 3000 & Glass & $10.0 \%$ & $20.7 x$ & $45.6 \%$ & $50.2 \%$ & 30.2 & $40.5 \%$ & $40.0 \%$ & $40.0 \%$ & $56.6 \%$ & & $-21.5 \%$ & $-17.1 \%$ & $-2.1 x$ & $-5.6 x$ & $-12.6 x$ & 31.24 & $22.3 \%$ & \\
\hline 3320 & Fumiture & $14.0 \mathrm{~m}$ & $32.0 \%$ & $50.0 \%$ & $115.0 x$ & 02.22 & $13.5 \%$ & $22.6 \%$ & $30.7 \%$ & $52.6 \%$ & 62.9 & $1.1 \%$ & $10.0 x$ & $23.2 \%$ & $00.0 \%$ & $0 . \pi \times$ & $47.0 \%$ & $30.0 \%$ & .. \\
\hline 3219 & Textices nec & $19.5 \%$ & $20.5 \%$ & $01.0 \%$ & $78.6 x$ & $01.0 \times$ & $40.8 \%$ & $40.3 \%$ & $88.5 \%$ & $84.4 \%$ & $8.0 x$ & $-30.3 \%$ & $-16.6 \%$ & $-20.7 x$ & $-5.0 x$ & $-23.4 x$ & 42.2\% & $36.2 \%$ & 0. \\
\hline 30032 & TV, communication & $60.0 \%$ & 72.5\% & $71.1 \%$ & $82.1 \%$ & $\infty .6 \times$ & 81.06 & $50.4 \%$ & $54.0 \%$ & $70.6 \%$ & & $5.1 \%$ & $22.1 \%$ & $16.2 \%$ & $11.6 \%$ & $10.2 x$ & $32.0 \%$ & $27.4 x$ & . \\
\hline 3114 & Fish canning & $8.0 \%$ & $7.2 \%$ & $0.3 \%$ & $12.0 \%$ & $12.5 \times$ & $86.3 x$ & $68.0 \%$ & $03.0 \%$ & $50.4 \%$ & 57.09 & $50.3 \%$ & $-50.8 \times$ & $-63.7 x$ & $-4.0 \%$ & -45.34 & $7.6 \%$ & $2.5 \%$ & . \\
\hline 3012 & Moted Fumiture & 12.14 & $11.8 \%$ & $17.1 \%$ & $20.1 \%$ & $30.5 \times$ & $0.5 \times$ & $8.6 \%$ & $15.9 \%$ & $18.1 \%$ & 22.14 & $3.6 \%$ & $3.0 \%$ & $1.2 \%$ & $11.0 \%$ & 8.49 & $10.4 \%$ & $13.6 \%$ & 4.69 \\
\hline 3321 & Paints, vernishes & $0.5 \%$ & $13.5 \%$ & $10.2 \%$ & $23.5 x$ & $20.2 x$ & $16.7 \times$ & $15.0 \%$ & $21.1 \%$ & $28.1 \%$ & $20.1 \times$ & $-7.1 \%$ & $-2.1 \%$ & $-4.9 \%$ & $-4.6 x$ & $-2.8 x$ & $16.7 \%$ & $12.4 x$ & 4.39 \\
\hline 3030 & Eec. epperatus ned & $12.4 \times$ & $21.0 \%$ & $29.1 \%$ & $31.1 \times$ & $2.5 \times$ & $39.6 \%$ & $40.2 \%$ & $46.1 \%$ & $54.1 \%$ & $43.1 \times$ & $.21 .4 \%$ & $-18.3 \times$ & $-19.1 \%$ & $.22 .0 \%$ & $-17.0 x$ & $13.1 \%$ & $0.3 x$ & 3.8 \\
\hline 3043 & Motor Vethicies & $30.2 \%$ & $04.0 \%$ & $88.0 \%$ & $120.8 x$ & $74.6 \times$ & $42.1 \%$ & $4.1 \%$ & $46.7 x$ & $62.7 x$ & $54.0 x$ & $17.2 \%$ & $20.6 \%$ & $30.2 \%$ & $64.2 \%$ & $20.8 \times$ & $15.0 \%$ & $11.0 \%$ & \\
\hline 3023 & Eec. appliences & $25.8 \%$ & $41.7 x$ & $49.8 \%$ & $81.1 \%$ & $\infty .2 x$ & $20.0 \times$ & $51.3 \%$ & $39.2 x$ & $68.4 x$ & $20.0 x$ & $-4.1 \%$ & $-0.6 x$ & $10.6 \%$ & $12.7 x$ & $-0.8 x$ & $43.4 \%$ & $40.1 \times$ & \\
\hline 3117 & Bakery products & $4.0 \%$ & $3.7 \%$ & $4.4 \%$ & $7.0 \%$ & $0.1 \times$ & $3.3 \%$ & $4.3 \%$ & $5.6 x$ & $5.4 \%$ & $5.0 x$ & $0.0 \%$ & $-0.0 \%$ & $-1.2 x$ & $1.0 \%$ & $3.5 \times$ & $8.1 \%$ & $2.3 x$ & \\
\hline 3312 & Wooden contrinters & $7.1 \%$ & $7.3 \%$ & $17.3 \%$ & $23.4 \times$ & $20.4 \times 4$ & $0.4 x$ & $9.2 \%$ & $20.1 x$ & $14.4 \%$ & $20.4 \times$ & $-2.3 x$ & $-1.0 \%$ & $-2.7 x$ & $0.0 \%$ & $0.0 x$ & 13.46 & $11.0 \%$ & \\
\hline 3211 & Spinning, meaving & is.5x & $21.2 \%$ & $25.5 \%$ & $33.2 \%$ & 40.1x & $46.0 \%$ & $56.0 \%$ & $60.9 x$ & $70.7 \%$ & 70.14 & $31.3 \%$ & $-34.6 \%$ & $-35.4 \%$ & $-37.5 \%$ & $30.0 x$ & $30.8 \%$ & $29.3 \%$ & \\
\hline 3412 & Conteiners & $10.0 \%$ & $10.5 \%$ & $19.7 x$ & $16.2 \%$ & $14.1 x$ & $4.4 x$ & $3.4 \%$ & $4.2 x$ & $5.0 \%$ & 7 & $5.0 \%$ & $7.1 \%$ & $0.5 \%$ & $11.2 \%$ & $0.4 \times$ & $4.1 \%$ & $3.4 \%$ & \\
\hline 3010 & Fab. mand noc & 20.26 & $27.1 \%$ & $31.0 \%$ & $30.0 x$ & 33.72 & $30.7 \%$ & $30.0 \%$ & $4.0 x$ & $46.1 \%$ & $43 . \pi x$ & $.10 .5 \%$ & $-11.7 x$ & $-12.7 \%$ & $-8.2 x$ & $-10.0 x$ & $13.5 \%$ & $13.0 \%$ & 0.6 \\
\hline
\end{tabular}


Table 3.4 External Performance of Swedish Industry

$M=$ imports, $X=$ Exports, $C=$ Production $+M-X$

(1000's Swedish kronor)

\begin{tabular}{|c|c|c|c|c|c|c|c|c|c|c|c|c|c|}
\hline \multirow[b]{2}{*}{ ISIC } & \multirow[b]{2}{*}{ Commodity } & \multicolumn{4}{|l|}{1970 Valued } & \multicolumn{4}{|l|}{1890 Values } & \multirow{2}{*}{$\begin{array}{c}\text { Chenge } \\
\text { in } \\
X-M\end{array}$} & \multicolumn{3}{|c|}{$\begin{array}{c}\text { Anrmual } \\
\text { Rate of Chenge }\end{array}$} \\
\hline & & $\bar{x}$ & $\mathbf{m}$ & C & $\overline{X-M}$ & $\bar{x}$ & $M$ & $\mathrm{c}$ & $\overline{x-M}$ & & $\bar{x}$ & $\mathbf{M}$ & $\mathrm{c}$ \\
\hline \multicolumn{14}{|c|}{ 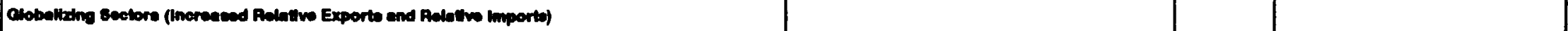 } \\
\hline 3411 & Pulp, peper & 5,600 & 138 & 2,700 & 5,522 & 42,400 & 2,142 & 01,000 & 40,337 & 34,815 & $11 x$ & $16 \%$ & $1 \pi$ \\
\hline 3848 & Motor Vehictes & 3,205 & 2.277 & 5,411 & 928 & 47,448 & 34,262 & 70,020 & 13,180 & 12,257 & $14 x$ & $15 \%$ & 14 \\
\hline 3820 & Machinery nec & 2,628 & 1,244 & 5,800 & 083 & 24,191 & 17,130 & 30,155 & 7,001 & 0,378 & $12 x$ & $11 \%$ & \\
\hline 3418 & Pulp, peper nec & 282 & 182 & 351 & 100 & 5,007 & 2,008 & 0.486 & 3,700 & 3,000 & $10 \%$ & $13 \%$ & 16 \\
\hline 3522 & Drugs \& medicines & 167 & 340 & 788 & (178) & 0,300 & 3,810 & 0,201 & 2,580 & 2,768 & $20 x$ & $13 \%$ & 13 \\
\hline 3632 & TV, communication & 1,354 & 1,232 & 2,370 & 122 & 18,502 & 10,385 & 22,791 & 2,117 & 1.000 & $14 x$ & $14 \%$ & 12 \\
\hline 3823 & Metal, woodworking & 503 & 550 & 756 & 43 & 0,804 & 8.091 & 5,835 & 1,712 & 1,070 & $13 \times$ & $12 \%$ & 11 \\
\hline 3529 & Chemicale nec & 200 & 572 & 1,122 & (223) & 8,030 & $4, \pi 0$ & 8,523 & 800 & 1,182 & $10 x$ & $11 \%$ & \\
\hline 3651 & Prot \& sclentific & 352 & 082 & 840 & (311) & 8,000 & 7,271 & 0,200 & 825 & 1,150 & $17 \pi$ & $13 \%$ & 15 \\
\hline 3320 & Fumiture & 100 & 175 & 1,200 & 14 & 4.043 & 3,419 & 7,127 & $\infty 00$ & 615 & $17 x$ & $16 \%$ & \\
\hline 3318 & Wood, cork nec & 58 & 30 & 271 & 25 & 802 & 328 & 1,322 & 504 & 530 & $15 x$ & $12 \%$ & \\
\hline 3813 & Structural motel & 224 & 150 & 1,820 & 75 & 2,012 & 1,054 & 13.701 & 350 & 204 & $12 x$ & $13 \%$ & 119 \\
\hline 3412 & Conteiners & 8 & 37 & 035 & 47 & 715 & 302 & 5,378 & 323 & 270 & $11 x$ & $13 \%$ & 10 \\
\hline 3117 & Bakery products & 58 & 49 & 1,472 & ? & $n 00$ & 133 & 7,004 & 200 & 257 & $13 x$ & $12 \%$ & \\
\hline 3812 & Motal Fumiture & 47 & 33 & 302 & 14 & 715 & 518 & 2,540 & 197 & 183 & $15 \%$ & $15 \%$ & 10 \\
\hline 3231 & Terneries & 117 & 137 & 204 & (10) & 418 & 354 & 518 & a & $\boldsymbol{\infty}$ & $7 \pi$ & $\mathbf{5 *}$ & 5 \\
\hline 3840 & Transport nec & 27 & 10 & 70 & 17 & $2+6$ & 180 & 501 & 28 & 11 & $11 \%$ & $10 \%$ & 109 \\
\hline 3312 & Wooden containere & - & $\mathbf{B}$ & 87 & (2) & 85 & 8 & 417 & 0 & 2 & $14 \times$ & $12 \%$ & en \\
\hline 3030 & Exec. eppliences & 114 & 132 & 442 & (18) & 1.050 & 1,873 & 2.052 & (22) & (4) & $15 \%$ & $14 \times$ & 9 \\
\hline 3110 & Chocolete, suger cont. & 35 & 105 & 522 & (71) & $\infty 1$ & 1,045 & 3,311 & (113) & (43) & $18 \%$ & $12 \%$ & $10 \%$ \\
\hline 313 & Sont dinks & 2 & 10 & 173 & (B) & 40 & 108 & 300 & (50) & (51) & $10 \%$ & $12 \%$ & \\
\hline 3521 & Peirta, vamtahese & 57 & 100 & 500 & (43) & $\infty 00$ & 1,055 & 3,522 & $(104)$ & (82) & $15 \%$ & $15 \%$ & $9 x$ \\
\hline 3215 & Cordege, rope & $\mathbf{3}$ & 17 & $\$$ & (13) & 19 & 105 & 74 & (8) & (73) & $\mathbf{m}$ & $10 \%$ & 2 \\
\hline 3002 & Cement, time & 1 & 10 & 302 & (B) & $\infty$ & 147 & 805 & (84) & (75) & $21 x$ & $14 \%$ & 4 \\
\hline 3002 & Musical ines. & 8 & 43 & 67 & (30) & $\infty$ & 272 & 24 & (223) & (188) & $10 \%$ & $10 \%$ & $-5 x$ \\
\hline 3000 & Sporting, ethletic & $\boldsymbol{\omega}$ & 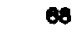 & 110 & (e) & 415 & 016 & 322 & (201) & (198) & $10 x$ & $12 \pi$ & $6 x$ \\
\hline 3218 & Teatilea noe & $\infty$ & 245 & $\infty 2$ & (140) & 920 & 1,200 & 1,144 & (340) & $(200)$ & $12 x$ & ox & 49 \\
\hline 3116 & Grin mill & 14 & 50 & 700 & (41) & 101 & 373 & 2,025 & (272) & (231) & $10 x$ & $10 \%$ & \\
\hline 3140 & Tobaccoo & 16 & 72 & 300 & (56) & 125 & 438 & 1,805 & (313) & (257) & $11 x$ & $\mathbf{9 x}$ & 89 \\
\hline
\end{tabular}




\begin{tabular}{|c|c|c|c|c|c|c|c|c|c|c|c|c|c|}
\hline \multirow[b]{2}{*}{ ISIC } & \multirow[b]{2}{*}{ Commodity } & \multicolumn{4}{|l|}{1970 Values } & \multicolumn{4}{|l|}{1960 Vaiues } & \multirow{2}{*}{$\begin{array}{c}\text { Chenge } \\
\text { in } \\
X-M\end{array}$} & $\begin{array}{c}\text { Arnued } \\
\text { Pate of Chenge }\end{array}$ & \multirow[b]{2}{*}{$\mathbf{M}$} & \multirow[b]{2}{*}{ C } \\
\hline & & $\bar{x}$ & $\bar{M}$ & $c$ & $x-M$ & $\bar{x}$ & $\bar{M}$ & C & $\overline{x-M}$ & & & & \\
\hline \multicolumn{14}{|c|}{ 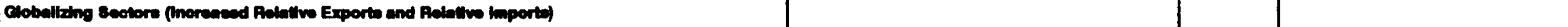 } \\
\hline 3620 & Glas: & 100 & 230 & 500 & (122) & 9,707 & 2.135 & 2,072 & (420) & $(30 \pi)$ & $15 \%$ & 124 & $\boldsymbol{m}$ \\
\hline 3091 & Stuctural clay & 42 & 128 & 313 & $(8 \pi)$ & 160 & 005 & $\mathbf{\infty}$ & $(467)$ & (380) & $\mathbf{7 \pi}$ & $\mathbf{8 x}$ & 49 \\
\hline 3500 & Plestics nec & 124 & 318 & 1,036 & (194) & 2,000 & $\mathbf{3 , 3 8 1}$ & 8,301 & (681) & (487) & $17 \%$ & $13 \%$ & $11 x$ \\
\hline $\mathbf{3 6 1 0}$ & Pottery, china & $\sqrt{5}$ & 84 & 201 & (D) & 442 & 907 & 095 & (525) & (516) & ox & $13 x$ & $7 x$ \\
\hline 3212 & Mado-up textileo & 45 & 120 & 415 & (84) & sen & 1,002 & 1,000 & (2028) & (644) & $12 \pi$ & $11 \%$ & $\pi x$ \\
\hline 3822 & Agricultured mach. & 324 & 271 & 802 & 54 & 1,700 & 2,200 & 1,700 & (506) & (550) & ox & $11 \%$ & $3 x$ \\
\hline 3720 & Non-ferrous motels & 800 & 1,758 & 4,045 & (809) & 7,025 & 8.511 & 14,732 & $(1,400)$ & (578) & $11 \%$ & $8 *$ & $7 x$ \\
\hline 3600 & Non-meted minerds & 110 & 200 & 2,249 & (90) & 1,192 & 1,035 & 10,335 & (74) & (65a) & $12 \pi$ & $12 \%$ & $\theta x$ \\
\hline 3233 & Leedher & 28 & $\infty$ & 178 & (34) & 140 & $\infty 00$ & 257 & $(717)$ & (083) & ox & $14 x$ & $2 x$ \\
\hline 3214 & Cerpeta, ngs & 21 & 200 & 320 & (182) & 204 & 1,007 & 122 & (692) & (710) & $12 x$ & ox & $-5 x$ \\
\hline 3211 & Spinning, weaving & 201 & 875 & 1,870 & (584) & 2,035 & 3,300 & 3,080 & $(1,325)$ & (741) & $10 \%$ & $7 \%$ & $3 \times$ \\
\hline 3550 & Rubber nec & 123 & 203 & 700 & (79) & 1,580 & 2,424 & 3,372 & (855) & (750) & $14 x$ & $13 \%$ & $8 x$ \\
\hline 3641 & Shipbullding & 1,500 & 451 & 1,000 & 1,148 & 2,726 & 2,414 & 2,872 & 312 & (836) & $\mathbf{3 x}$ & ox & $2 \times$ \\
\hline 3121 & Food noce & 30 & 200 & 1,345 & (186) & 533 & 1,501 & 4,375 & $(1,028)$ & (803) & $14 \%$ & $11 \%$ & $0 x$ \\
\hline 3523 & Soap, commetics & $\infty$ & 140 & 550 & (\$1) & 803 & 1,872 & 1,480 & $(1, \infty 00)$ & $(01 \pi)$ & $15 \%$ & $14 x$ & $5 \times$ \\
\hline 3631 & Eec. ind. mach. & $4 \pi 0$ & 5010 & 1,172 & (70) & 4,602 & 5,675 & $5, \pi 80$ & $(1,084)$ & $(1,008)$ & $12 \%$ & $12 \%$ & $8 x$ \\
\hline 3845 & Areran & 140 & 350 & 1,500 & (210) & 4,042 & 5,306 & 0,500 & $(1,340)$ & $(1,133)$ & $18 \%$ & $15 \%$ & $9 x$ \\
\hline 3113 & Frutt, vog. comming & $\mathbf{s 0}$ & 273 & 1,192 & (235) & 507 & 2,000 & $\mathbf{5 , 5 3 0}$ & $(1,550)$ & $(1,324)$ & $14 \%$ & $11 \%$ & 8 \\
\hline 3420 & Printing, publisting & 130 & 24 & 3,607 & (96) & 1,700 & 3,150 & 20,000 & $(1,423)$ & $(1,328)$ & $13 x$ & $14 x$ & $11 \%$ \\
\hline 3114 & Fish carning & 31 & 3a1 & 017 & (310) & 454 & 2.100 & 1,065 & $(1,045)$ & $(1,335)$ & $14 \%$ & $10 \%$ & $\boldsymbol{\infty}$ \\
\hline 3000 & Mant. ind. nec & 04 & 207 & 40 & (203) & 21 & 2,527 & Ben & $(1, \infty \infty)$ & $(1,403)$ & $12 \%$ & $11 \%$ & $3 \times$ \\
\hline 3652 & Photo, optical & $\infty$ & 200 & 200 & (2003) & 870 & 2,858 & 702 & $(1,002)$ & $(1,770)$ & $12 \%$ & $12 \%$ & $5 \times$ \\
\hline 3240 & Footurer & $\infty$ & 200 & 518 & (223) & 332 & 2,474 & 360 & $(2,142)$ & $(1,919)$ & $8 \times$ & $11 \%$ & $-2 x$ \\
\hline 3830 & Elec. epperetait nec & 208 & 813 & 2,400 & (515) & 9,004 & 0,000 & 11,040 & $(2,405)$ & $(1,970)$ & $13 \%$ & $11 \%$ & $8 x$ \\
\hline 3513 & Symthathic resins & 491 & 1,203 & 1,929 & (722) & 7,700 & 10,517 & 12,550 & $(2,800)$ & $(2,087)$ & $15 \%$ & $11 \%$ & $10 x$ \\
\hline 3810 & Fab. mated nec & 070 & 1,487 & 4,850 & (509) & 9,844 & 12,750 & 20,290 & $(2, \infty 00)$ & $(2,307)$ & $12 \%$ & $11 \%$ & $0 x$ \\
\hline 3511 & Industried chemicels & 613 & 1,2003 & 2,100 & (680) & 0,300 & 9,000 & 12,825 & $(3, \infty \infty 0)$ & $(2,020)$ & $12 \%$ & $11 \%$ & $\infty$ \\
\hline \multirow[t]{2}{*}{3220} & Wearing epperel & 202 & 785 & 2,487 & $(504)$ & 1,190 & 8,412 & 2,450 & $(7,213)$ & $(0,70 \theta)$ & $6 \%$ & $13 \mathbf{x}$ & $-0 x$ \\
\hline & TOTAL & 23,286 & 22,854 & 70,831 & 432 & 246,246 & 216,002 & 408,120 & 30,184 & 20,752 & & & \\
\hline
\end{tabular}


Table 3.4 continued

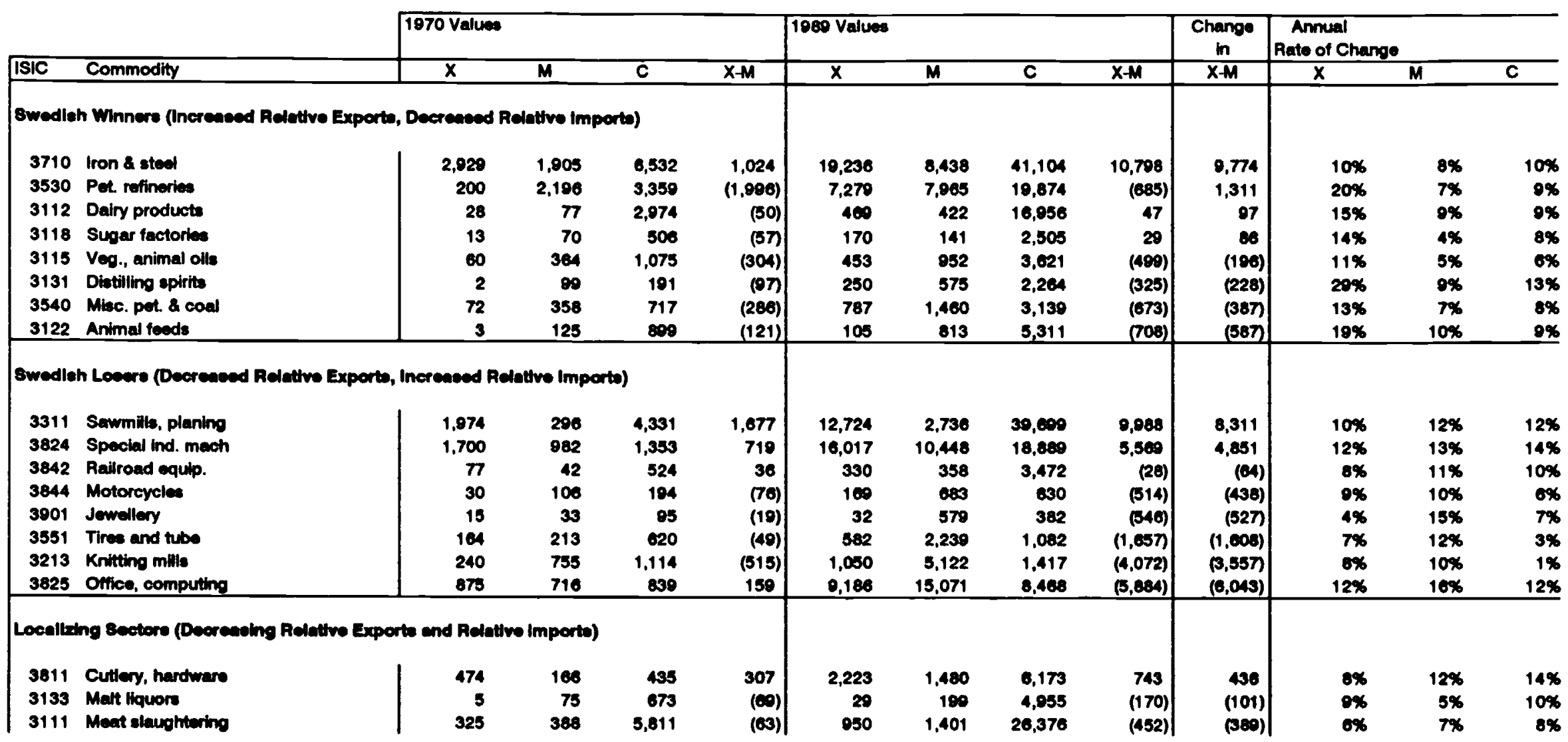


Table 3.5 Swedish Revealed Comparative Advantage Relative Share of OECD Output

\begin{tabular}{|c|c|c|c|c|c|c|c|}
\hline Commodity & ISIC & $1970^{\star}$ & $1975^{\star}$ & $1980 *$ & $1985 *$ & $1990 * *$ & \begin{tabular}{|l|} 
Ratio \\
$1990 / 1970$ \\
\end{tabular} \\
\hline \multicolumn{2}{|c|}{1970 Comparatlve Advantage } & & & & & & \\
\hline $\begin{array}{l}\text { Wood } \\
\text { Paper } \\
\text { Fabricated metal } \\
\text { Misc. petro } \\
\text { Food } \\
\text { Machinery } \\
\text { Ind. Chemicals } \\
\text { Other non-metal } \\
\text { Fumiture } \\
\text { Printing }\end{array}$ & $\begin{array}{l}331 \\
341 \\
381 \\
354 \\
311 \\
382 \\
351 \\
369 \\
332 \\
342\end{array}$ & $\begin{array}{l}2.64 \\
2.42 \\
1.04 \\
1.10 \\
1.23 \\
1.25 \\
1.05 \\
1.04 \\
1.23 \\
1.32\end{array}$ & $\begin{array}{l}2.77 \\
2.79 \\
1.12 \\
0.95 \\
0.93 \\
1.35 \\
1.08 \\
0.84 \\
1.20 \\
1.26\end{array}$ & $\begin{array}{l}3.10 \\
2.68 \\
1.19 \\
1.06 \\
1.02 \\
1.22 \\
0.64 \\
0.84 \\
1.12 \\
1.33\end{array}$ & $\begin{array}{l}3.03 \\
2.66 \\
1.13 \\
1.16 \\
0.98 \\
1.15 \\
0.63 \\
0.74 \\
1.27 \\
1.38\end{array}$ & $\begin{array}{l}3.58 \\
3.15 \\
1.31 \\
1.25 \\
1.05 \\
0.99 \\
0.83 \\
0.82 \\
0.90 \\
0.94\end{array}$ & $\begin{array}{l}1.36 \\
1.30 \\
1.26 \\
1.13 \\
0.85 \\
0.79 \\
0.79 \\
0.78 \\
0.73 \\
0.71\end{array}$ \\
\hline Total Manufactures & 3 & 1.00 & 1.00 & 1.00 & 1.00 & 1.00 & 1.00 \\
\hline \multicolumn{2}{|c|}{1970 Comparaflve Dleadvantage } & & & & & & \\
\hline $\begin{array}{l}\text { Petroleum } \\
\text { Iron \& steel } \\
\text { Beverage } \\
\text { Prof. \& Scien. } \\
\text { Other chemicals } \\
\text { Other food } \\
\text { Nonferrous metal } \\
\text { Transport equip } \\
\text { Plastics } \\
\text { Tobacco } \\
\text { Elec. machinery } \\
\text { Rubber } \\
\text { Glass } \\
\text { Pottery, china } \\
\text { Textiles } \\
\text { Leather } \\
\text { Other manufactures } \\
\text { Footwear }\end{array}$ & $\begin{array}{l}353 \\
371 \\
313 \\
385 \\
352 \\
312 \\
372 \\
384 \\
356 \\
314 \\
383 \\
355 \\
362 \\
361 \\
321 \\
323 \\
390 \\
324\end{array}$ & $\begin{array}{l}0.35 \\
0.86 \\
0.38 \\
0.55 \\
0.65 \\
0.85 \\
0.97 \\
0.90 \\
0.44 \\
0.26 \\
0.72 \\
0.82 \\
0.89 \\
0.91 \\
0.62 \\
0.89 \\
0.54 \\
0.41\end{array}$ & $\begin{array}{l}0.39 \\
0.80 \\
0.38 \\
0.62 \\
0.62 \\
0.73 \\
0.80 \\
1.11 \\
0.47 \\
0.24 \\
0.94 \\
0.74 \\
0.77 \\
0.84 \\
0.55 \\
0.71 \\
0.55 \\
0.41\end{array}$ & $\begin{array}{l}0.70 \\
0.94 \\
0.46 \\
0.58 \\
0.80 \\
0.98 \\
0.92 \\
1.03 \\
0.53 \\
0.25 \\
0.82 \\
0.73 \\
0.96 \\
0.68 \\
0.48 \\
0.55 \\
0.54 \\
0.36\end{array}$ & $\begin{array}{l}0.91 \\
1.02 \\
0.48 \\
0.61 \\
0.77 \\
1.00 \\
0.89 \\
1.07 \\
0.46 \\
0.26 \\
0.80 \\
0.67 \\
0.85 \\
0.82 \\
0.41 \\
0.56 \\
0.53 \\
0.22\end{array}$ & $\begin{array}{l}0.65 \\
1.46 \\
0.61 \\
0.77 \\
0.83 \\
1.05 \\
1.09 \\
1.00 \\
0.46 \\
0.27 \\
0.69 \\
0.62 \\
0.65 \\
0.64 \\
0.31 \\
0.36 \\
0.21 \\
0.14\end{array}$ & $\begin{array}{l}1.84 \\
1.70 \\
1.62 \\
1.39 \\
1.28 \\
1.23 \\
1.12 \\
1.11 \\
1.03 \\
1.01 \\
0.96 \\
0.76 \\
0.73 \\
0.70 \\
0.51 \\
0.41 \\
0.39 \\
0.35\end{array}$ \\
\hline Wearing Apparel & 322 & 0.68 & 0.53 & 0.44 & 0.26 & 0.20 & 0.30 \\
\hline
\end{tabular}

* Excludes production of Iceland and Switzerland

** Excludes production of Australia, Belgium, and Ireland 
Table 3.6 OECD Manufacturing Value Added Shares

\begin{tabular}{|l|rr|r|}
\cline { 2 - 4 } \multicolumn{1}{c|}{} & 1976 & 1990 & $\begin{array}{r}\text { Aatio of } \\
1990 / 1975\end{array}$ \\
\hline Plastics nec & $1.76 \%$ & $2.97 \%$ & 1.69 \\
Other chemicals & $3.25 \%$ & $5.47 \%$ & 1.68 \\
Printing, publishing & $4.52 \%$ & $5.99 \%$ & 1.32 \\
Elec. machinery & $8.80 \%$ & $11.11 \%$ & 1.26 \\
Professional equip. & $2.52 \%$ & $3.10 \%$ & 1.23 \\
Non-metal minerals & $2.22 \%$ & $2.41 \%$ & 1.08 \\
Machinery & $11.71 \%$ & $12.46 \%$ & 1.06 \\
Pottery, china & $0.22 \%$ & $0.24 \%$ & 1.06 \\
Food manf. & $7.76 \%$ & $8.19 \%$ & 1.06 \\
Tobacco & $1.20 \%$ & $1.26 \%$ & 1.05 \\
\hline Total Mant. & $100.00 \%$ & $100.00 \%$ & 1.00 \\
\hline Transport & $11.06 \%$ & $11.04 \%$ & 1.00 \\
Glass & $0.87 \%$ & $0.84 \%$ & 0.97 \\
Furniture & $1.36 \%$ & $1.31 \%$ & 0.96 \\
Paper & $3.48 \%$ & $3.34 \%$ & 0.96 \\
Other mant. & $1.40 \%$ & $1.34 \%$ & 0.96 \\
Fabricated metal & $6.51 \%$ & $6.18 \%$ & 0.95 \\
Beverages & $1.97 \%$ & $1.73 \%$ & 0.88 \\
Industrial chemicals & $6.32 \%$ & $5.47 \%$ & 0.86 \\
Non-ferrous metals & $1.62 \%$ & $1.39 \%$ & 0.85 \\
Wood & $1.76 \%$ & $1.50 \%$ & 0.85 \\
Rubber & $1.38 \%$ & $1.16 \%$ & 0.84 \\
Misc. pet. \& coal & $0.25 \%$ & $0.21 \%$ & 0.83 \\
Petroleum refineries & $2.54 \%$ & $1.98 \%$ & 0.78 \\
Textiles & $3.91 \%$ & $2.73 \%$ & 0.70 \\
Iron and Steel & $5.24 \%$ & $3.53 \%$ & 0.67 \\
Wearing Apparel & $2.51 \%$ & $1.67 \%$ & 0.66 \\
Leather & $0.34 \%$ & $0.20 \%$ & 0.58 \\
Footwear & $0.51 \%$ & $0.23 \%$ & 0.46 \\
\hline
\end{tabular}


Table 3.7 Heckscher-Ohlin Trade As A Percent of Total Trade

|Exports-Imports | / (Exports + Imports)

\begin{tabular}{|c|c|c|c|c|c|c|c|}
\hline \multirow[b]{2}{*}{ ISIC } & \multirow[b]{2}{*}{ Commodity } & \multicolumn{5}{|c|}{ Heckscher-Ohlin Trade } & \begin{tabular}{|l|} 
Change \\
$1970-1989$
\end{tabular} \\
\hline & & 1970 & 1975 & 1980 & 1985 & 1989 & \\
\hline & AVERAGE & $30.5 \%$ & $23.2 \%$ & $17.2 \%$ & $13.2 \%$ & $18.3 \%$ & $-12.2 \%$ \\
\hline 3411 & Pulp, paper & $95.2 \%$ & $95.6 \%$ & $94.6 \%$ & $91.8 \%$ & $90.4 \%$ & $-4.8 \%$ \\
\hline 3122 & Animal feeds & $94.9 \%$ & $87.7 \%$ & $95.9 \%$ & $85.6 \%$ & $77.2 \%$ & $-17.7 \%$ \\
\hline 3118 & Sugar factories & $68.0 \%$ & $99.9 \%$ & $19.4 \%$ & $84.1 \%$ & $9.4 \%$ & $-58.6 \%$ \\
\hline 3311 & Sawmills, planing & $73.9 \%$ & $73.5 \%$ & $66.7 \%$ & $76.9 \%$ & $64.6 \%$ & $-9.3 \%$ \\
\hline 3240 & Footwear & $62.2 \%$ & $57.9 \%$ & $65.4 \%$ & $76.6 \%$ & $76.3 \%$ & $14.1 \%$ \\
\hline 3901 & Jewellery & $39.5 \%$ & $74.3 \%$ & $57.7 \%$ & $66.5 \%$ & $\mathbf{8 9 . 4 \%}$ & $49.9 \%$ \\
\hline 3113 & Fruit, veg. canning & $75.8 \%$ & $77.2 \%$ & $75.1 \%$ & $66.0 \%$ & $60.6 \%$ & $-15.2 \%$ \\
\hline 3114 & Fish canning & $83.3 \%$ & $\mathbf{7 7 . 9 \%}$ & $74.3 \%$ & $64.4 \%$ & $64.4 \%$ & $-18.9 \%$ \\
\hline 3220 & Wearing apparel & $49.1 \%$ & $54.0 \%$ & $65.2 \%$ & $64.3 \%$ & $75.0 \%$ & $26.0 \%$ \\
\hline 3213 & Knitting mills & $51.8 \%$ & $40.8 \%$ & $55.2 \%$ & $60.7 \%$ & $66.0 \%$ & $14.2 \%$ \\
\hline 3233 & Leather & $39.7 \%$ & $65.1 \%$ & $68.0 \%$ & $60.5 \%$ & $70.7 \%$ & $31.0 \%$ \\
\hline 3131 & Distilling spirits & $96.8 \%$ & $97.7 \%$ & $95.5 \%$ & $60.3 \%$ & $39.4 \%$ & $-57.4 \%$ \\
\hline 3849 & Transport nec & $47.1 \%$ & $58.3 \%$ & $53.4 \%$ & $55.6 \%$ & $6.9 \%$ & $-40.1 \%$ \\
\hline 3902 & Musical instr. & $69.4 \%$ & $70.3 \%$ & $64.1 \%$ & $54.4 \%$ & $69.4 \%$ & $0.0 \%$ \\
\hline 3214 & Carpets, rugs & $81.1 \%$ & $76.2 \%$ & $64.8 \%$ & $53.6 \%$ & $68.6 \%$ & $-12.5 \%$ \\
\hline 3412 & Containers & $39.2 \%$ & $50.9 \%$ & $53.3 \%$ & $52.5 \%$ & $29.2 \%$ & $-10.0 \%$ \\
\hline 3319 & Wood, cork nec & $27.1 \%$ & $21.7 \%$ & $27.3 \%$ & $51.2 \%$ & $46.2 \%$ & $19.1 \%$ \\
\hline 3551 & Tires and tube & $12.9 \%$ & $44.8 \%$ & $43.4 \%$ & $50.8 \%$ & $58.7 \%$ & $45.8 \%$ \\
\hline 3133 & Malt liquors & $86.9 \%$ & $74.5 \%$ & $40.3 \%$ & $48.5 \%$ & $74.6 \%$ & $-12.3 \%$ \\
\hline 3852 & Photo, optical & $52.2 \%$ & $61.2 \%$ & $53.4 \%$ & $48.4 \%$ & $53.1 \%$ & $0.9 \%$ \\
\hline 3116 & Grain mill & $59.0 \%$ & $37.8 \%$ & $41.7 \%$ & $48.3 \%$ & $57.3 \%$ & $-1.7 \%$ \\
\hline 3842 & Railroad equip. & $30.0 \%$ & $4.7 \%$ & $29.3 \%$ & $47.2 \%$ & $4.1 \%$ & $-25.9 \%$ \\
\hline 3710 & Iron \& steel & $21.2 \%$ & $14.9 \%$ & $33.4 \%$ & $47.0 \%$ & $39.0 \%$ & $17.8 \%$ \\
\hline 3811 & Cutlery, hardware & $48.1 \%$ & $45.5 \%$ & $42.1 \%$ & $45.0 \%$ & $20.1 \%$ & $-28.0 \%$ \\
\hline 3121 & Food nec & $67.8 \%$ & $48.5 \%$ & $56.5 \%$ & $44.9 \%$ & $49.1 \%$ & $-18.7 \%$ \\
\hline 3134 & Soft drinks & $63.7 \%$ & $46.9 \%$ & $\mathbf{3 7 . 7 \%}$ & $42.4 \%$ & $37.8 \%$ & $-25.8 \%$ \\
\hline 3419 & Pulp, paper nec & $21.6 \%$ & $29.0 \%$ & $32.4 \%$ & $41.7 \%$ & $46.9 \%$ & $25.3 \%$ \\
\hline 3844 & Motorcycles & $56.3 \%$ & $41.4 \%$ & $64.6 \%$ & $\mathbf{3 7 . 8 \%}$ & $60.4 \%$ & $4.0 \%$ \\
\hline 3523 & Soap, cosmetics & $48.5 \%$ & $52.6 \%$ & $46.8 \%$ & $37.7 \%$ & $36.9 \%$ & $-11.6 \%$ \\
\hline 3320 & Furniture & $3.9 \%$ & $18.2 \%$ & $24.0 \%$ & $37.4 \%$ & $8.4 \%$ & $4.5 \%$ \\
\hline 3211 & Spinning, weaving & $50.1 \%$ & $45.0 \%$ & $41.0 \%$ & $36.1 \%$ & $24.6 \%$ & $-25.6 \%$ \\
\hline 3813 & Structural metal & $19.9 \%$ & $31.9 \%$ & $25.0 \%$ & $35.9 \%$ & $9.8 \%$ & $-10.2 \%$ \\
\hline 3691 & Structural clay & $51.0 \%$ & $56.5 \%$ & $39.0 \%$ & $35.0 \%$ & $58.0 \%$ & $7.0 \%$ \\
\hline 3843 & Motor Vehicles & $16.9 \%$ & $19.1 \%$ & $28.7 \%$ & $33.8 \%$ & $16.1 \%$ & $-0.8 \%$ \\
\hline 3909 & Manf. ind. nec & $52.1 \%$ & $38.5 \%$ & $35.7 \%$ & $33.1 \%$ & 49.2\% & $-2.9 \%$ \\
\hline 3115 & Veg., animal oils & 71.7\% & $56.0 \%$ & $49.6 \%$ & $32.0 \%$ & $35.5 \%$ & $-36.1 \%$ \\
\hline 3540 & Misc. pet. \& coal & $66.4 \%$ & $70.4 \%$ & $42.4 \%$ & $29.1 \%$ & $29.9 \%$ & $-36.5 \%$ \\
\hline
\end{tabular}


Table 3.7 Continued

|Exports-Imports | / (Exports + Imports)

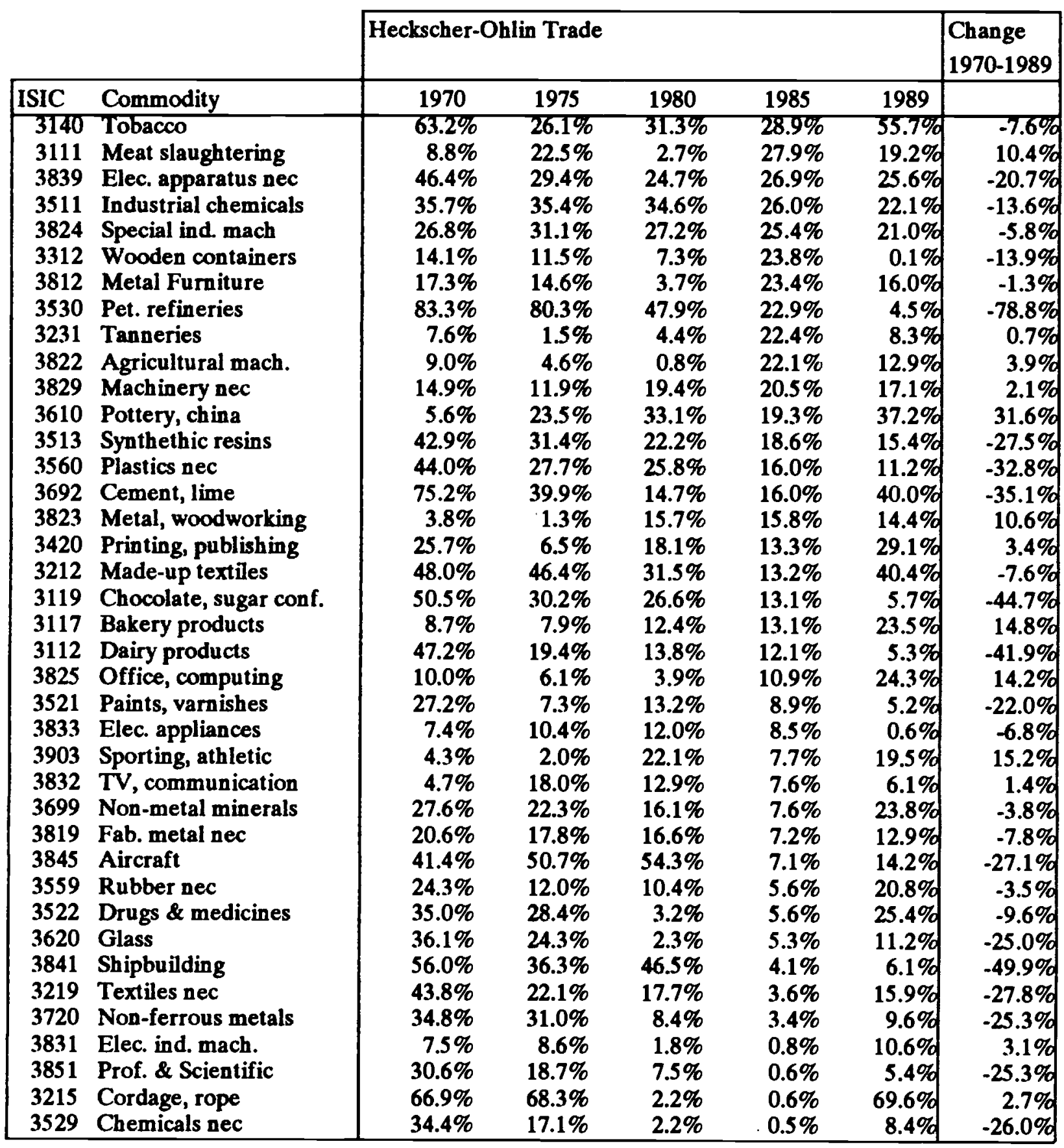


Table 4.1 Allocation of Capltal and Labor in Manufacturing Swoden (Capital in thousands of kronor)

\begin{tabular}{|c|c|c|c|}
\hline $\begin{array}{l}\text { Capltal/ } \\
\text { Employoe }\end{array}$ & $\begin{array}{r}\text { Employees } \\
1988 \\
\end{array}$ & $\begin{array}{c}\text { Total Fixed } \\
\text { Capital }\end{array}$ & Commodity \\
\hline 1214 & 1,600 & $1,942,305$ & Potroleum refineries \\
\hline 634 & 53,700 & $34,046,959$ & Paper Products \\
\hline 361 & 6,330 & $2,287,834$ & Food Products nec \\
\hline 302 & 8,100 & $2,443,078$ & Drugs and medicines \\
\hline 284 & 18,600 & $5,289,620$ & Industrial Chemicals \\
\hline 261 & 5,100 & $1,329,975$ & |Beverage Ind. \\
\hline 230 & 33,300 & $7,642,665$ & Iron and Steel \\
\hline 210 & 14,900 & $3,129,154$ & Cement, non-metallic mineral \\
\hline 206 & 9,300 & $1,914,837$ & Ottice, computing and accounting \\
\hline 163 & 56,970 & $9,288,233$ & Food Manf. \\
\hline 147 & 44,200 & $6,508,467$ & Wood and wood products \\
\hline 129 & 73,900 & $9,496,652$ & Fabricated Metal Products \\
\hline 126 & 11,300 & $1,421,193$ & Non-ferrous metal basic industries \\
\hline 122 & 112,600 & $13,771,537$ & Transport equipment \\
\hline 117 & 16,600 & $1,942,154$ & Other chemical products minus drugs \\
\hline 109 & 14,300 & $1,563,229$ & Plastic products nec \\
\hline 108 & 102,200 & $11,037,047$ & Machinery except electrical \\
\hline 108 & 42,700 & $4,591,917$ & Printing and publishing \\
\hline 99 & 4,300 & 425,011 & Glass and glass products \\
\hline 96 & 8,900 & 853,180 & Rubber products \\
\hline 89 & 67,600 & $6,002,803$ & Electrical Machinery \\
\hline 87 & 14,700 & $1,280,765$ & Textiles \\
\hline 85 & 3,800 & 321,382 & Other Manufacturing Industries \\
\hline 63 & 1,700 & 141,307 & Misc. products of pet. \& coal \\
\hline 66 & 2,500 & 164,438 & Pottery, china and earthenware \\
\hline 57 & 12,200 & 700,407 & Fumiture \\
\hline 51 & 13,400 & 686,079 & Professional and Scientific equip. \\
\hline 46 & 900 & 41,658 & Footwear \\
\hline 33 & 1,400 & 46,058 & Leather \\
\hline 23 & 9,000 & 209,349 & Wearing Apparol \\
\hline 170 & 760,100 & $730,519,291$ & Total Manufacturing \\
\hline & $07 \mathrm{mon}$ & 10555 & minus \\
\hline 414 & 97,900 & $40,555,425$ & $\begin{array}{l}\text { Wood and Paper Mant. } \\
\text { equals }\end{array}$ \\
\hline 135 & 668,200 & $89,963,866$ & Residual \\
\hline
\end{tabular}


LIST OF GRAPHS

3.1 Investment Share of GDP

3.2 Investment Share of GDP:Adjusted for Price Differences

3.3 Real Capital Stock per Non-Government Worker

3.4 Educational Expenditures as a Share of GDP

3.5 Tertiary Expenditures as a Proportion of Education Expenditure

3.6 Tertiary Expenditures as a Proportion of GDP

Enrollment rates in Tertiary Education

3.8 1965 Factor Supplies

$3.9 \quad 1988$ Factor Supplies

3.10 Net Exports per Worker: 1958

3.11 Net Exports per Worker: 1965

3.12 Net Exports per Worker: 1974

3.13 Net Exports per Worker, 1988

3.14 Forest Products Net Exports Per Worker, 1965 and 1988

3.15 Labor-Intensive Manufactures Net Exports Per Worker, 1965 and 1988

3.16 Capital Intensive Manufactures Net Exports Per Worker, 1965 and 1988

3.17 Machinery Net Exports Per Worker, 1965 and 1988

3.18 Chemicals Net Exports Per Worker, 1965 and 1988

3.19 Swedish Terms of Trade

3.20 1989 and 1992 Import and Export Price Indexes, $1968=100$

3.211989 and 1992 Import and Export Price Indexes, $1968=100$ (Detail)

5.1 Capital-Labor Ratios in Manufacturing Sectors 1962-1990 and Experiments 1-3

5.2 Manufacturing Production by Sector. In Percentage Shares., 1962-1991 


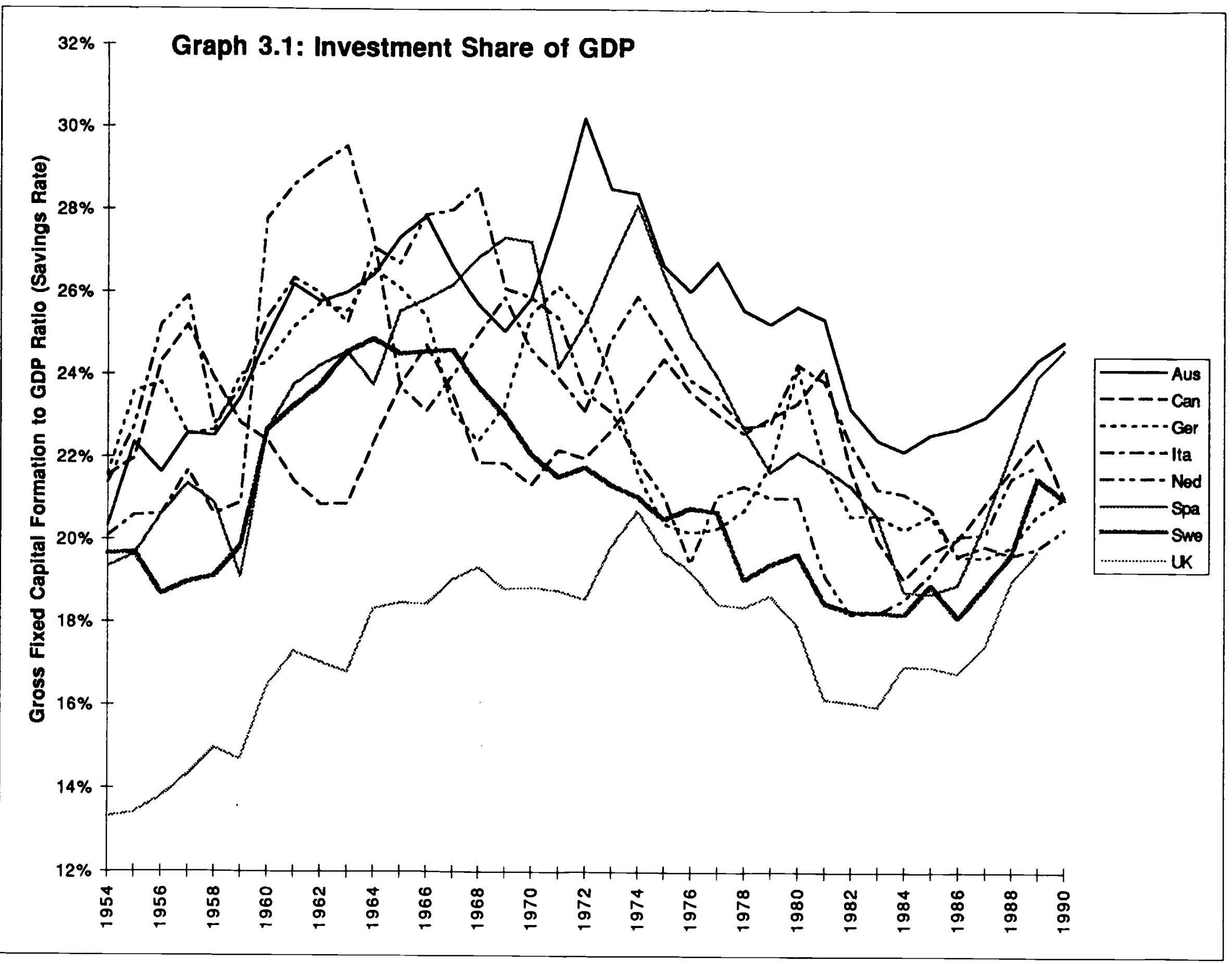




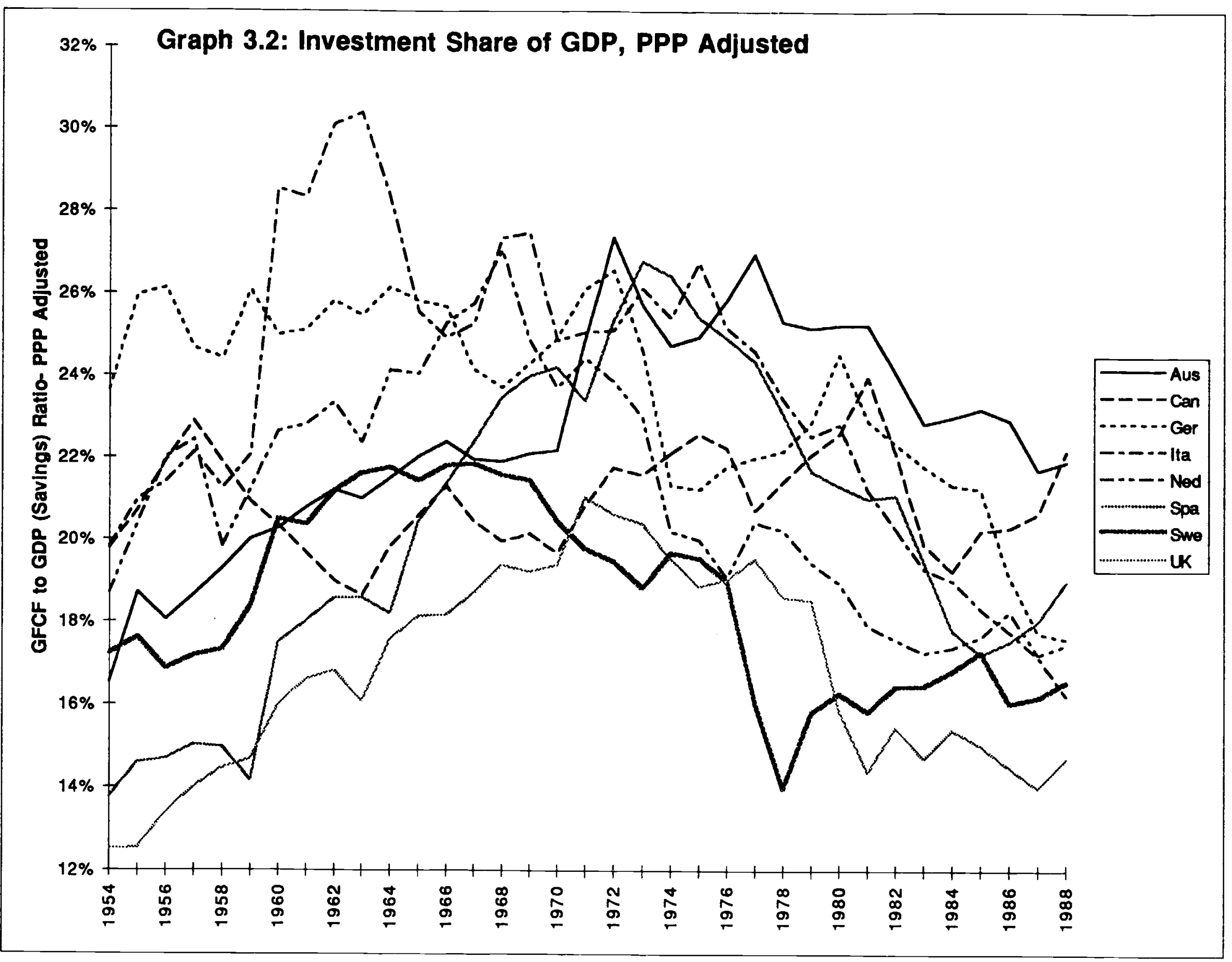




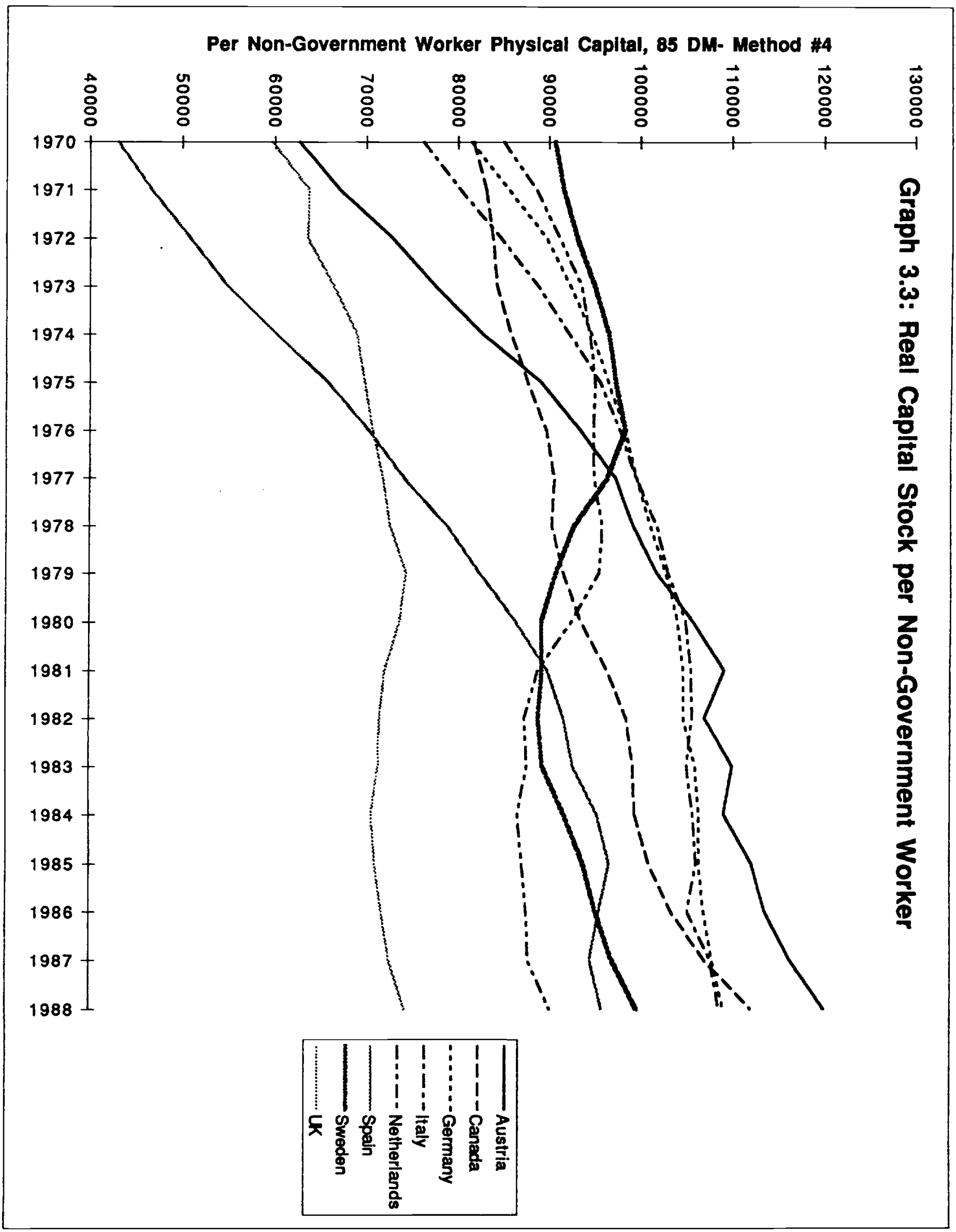




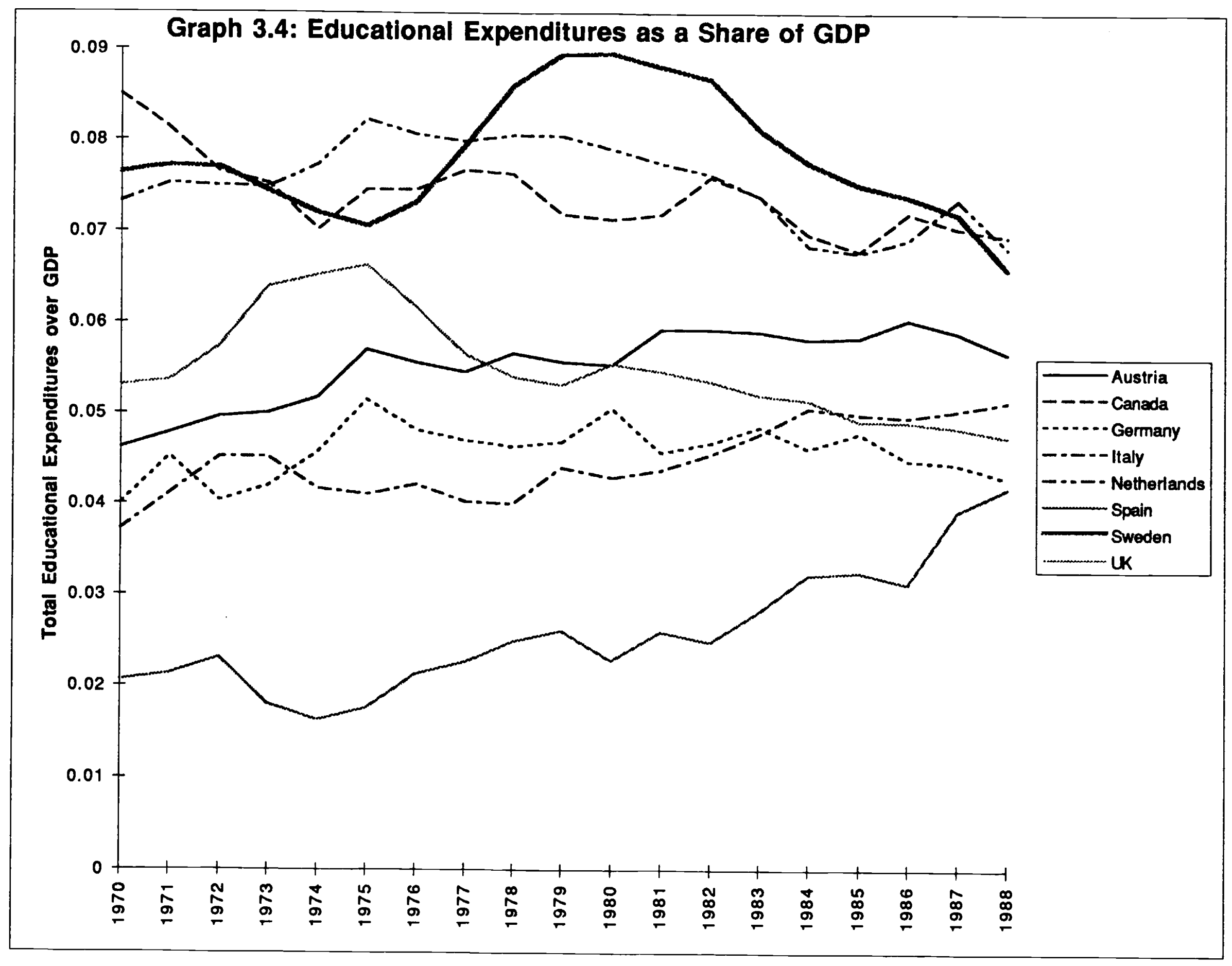




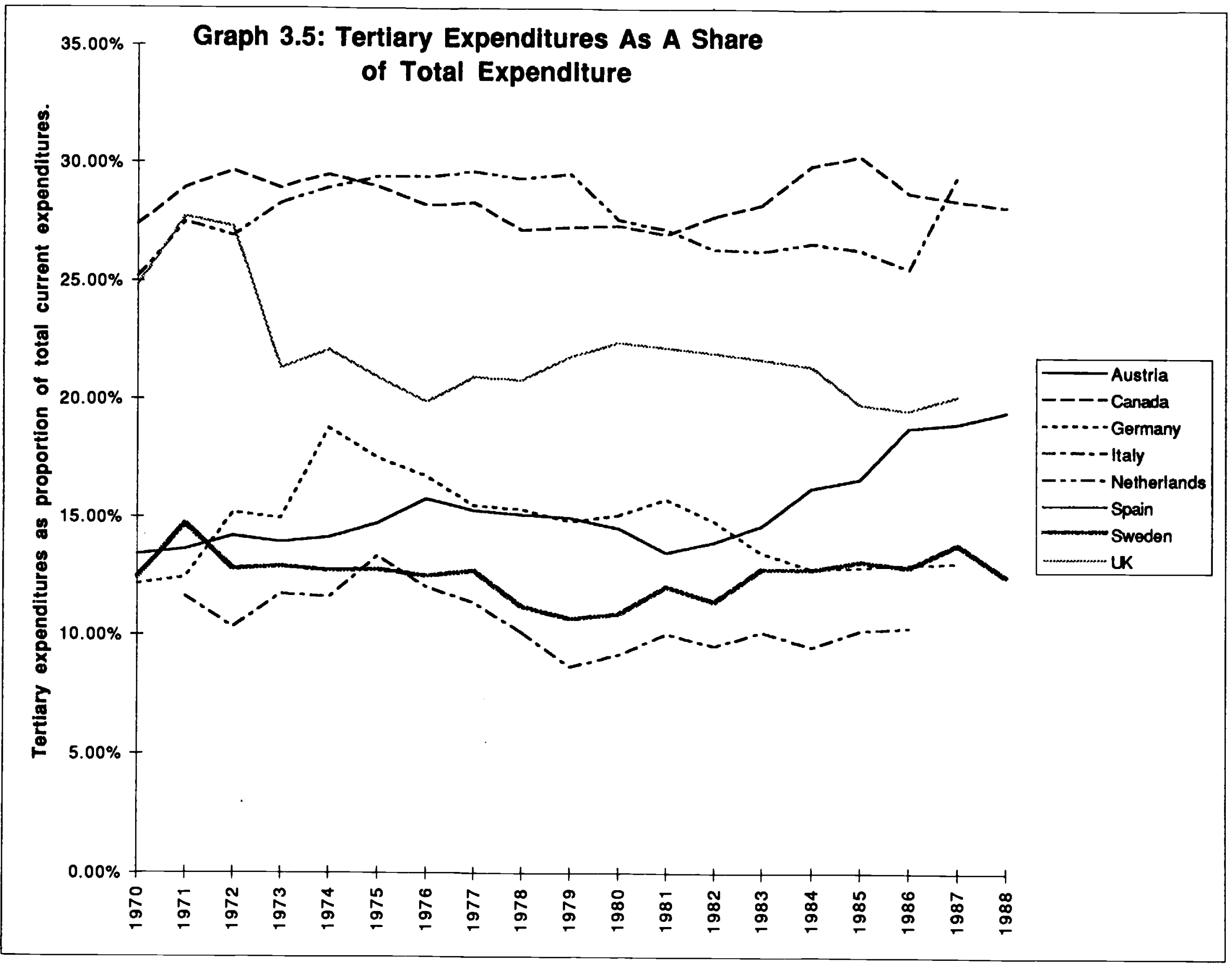




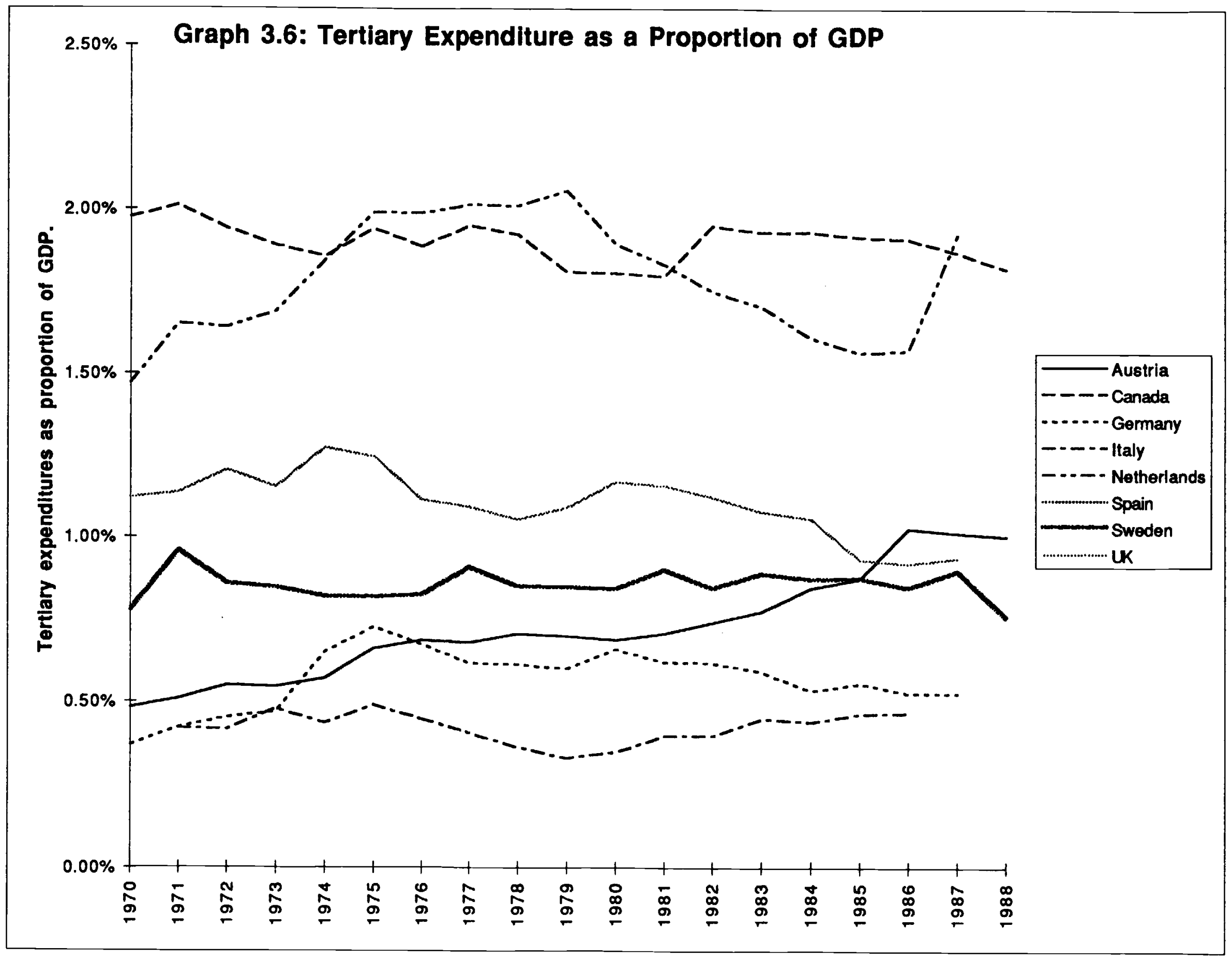




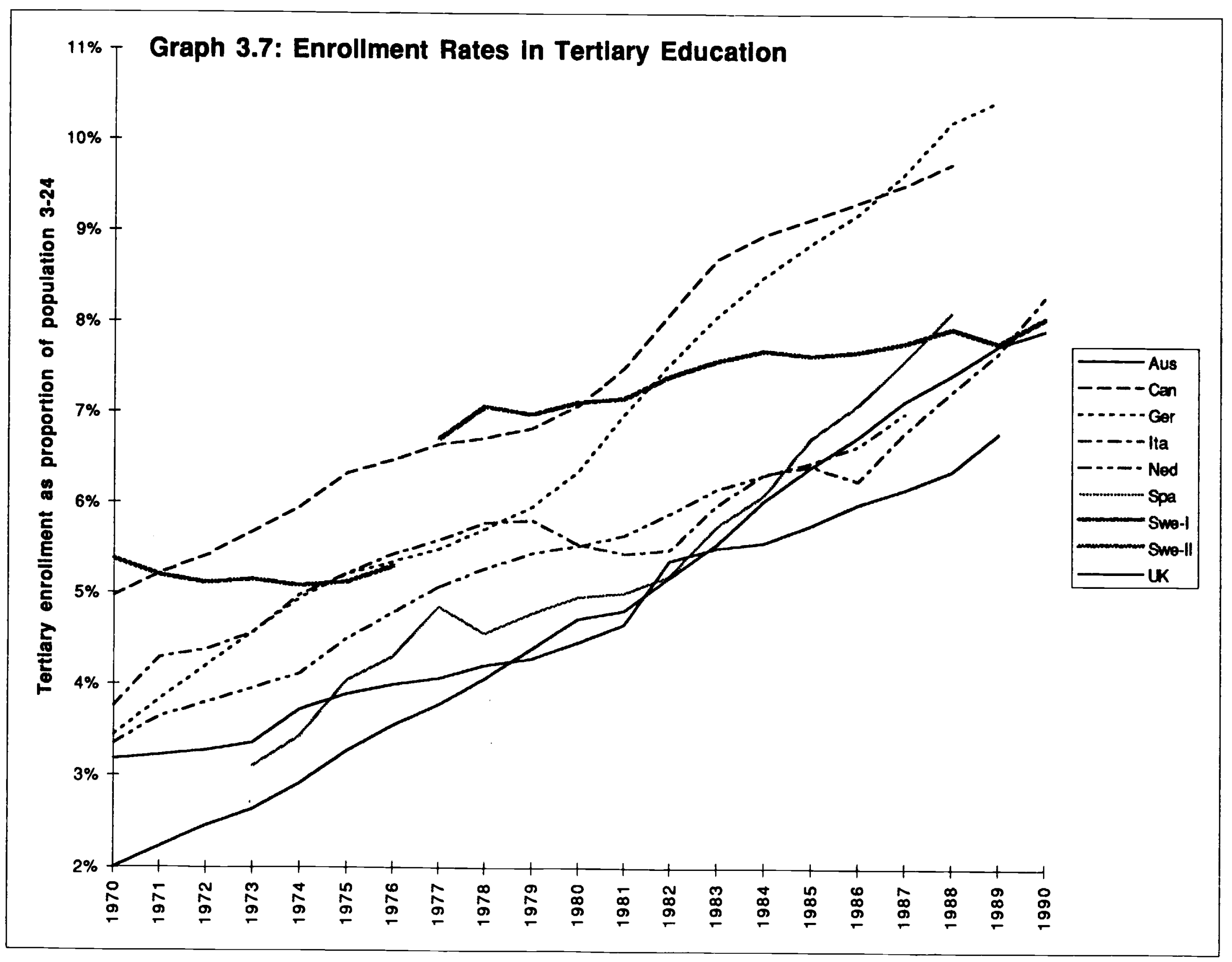




\section{Factor Supplies}

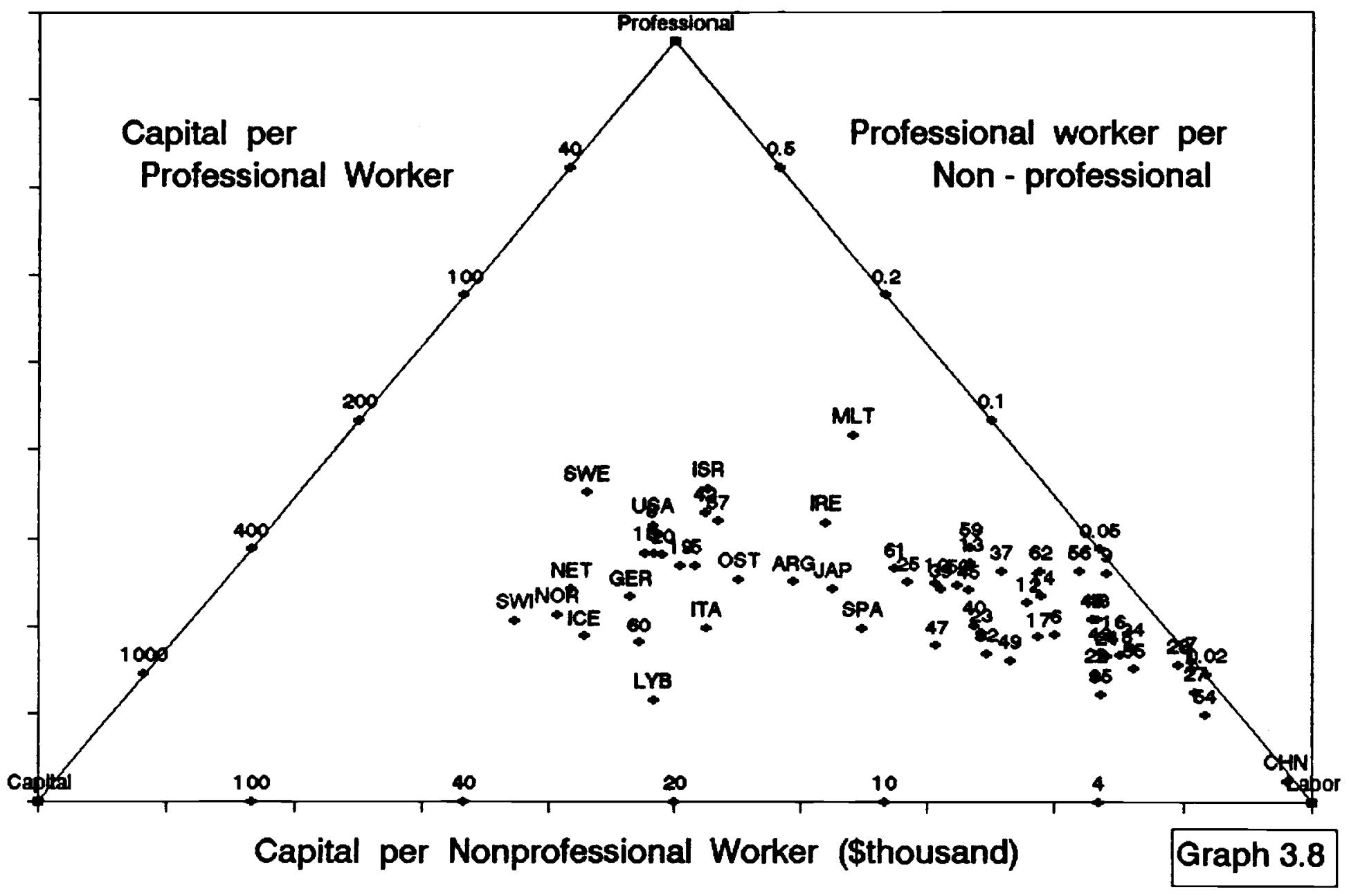




\section{Factor Supplies}

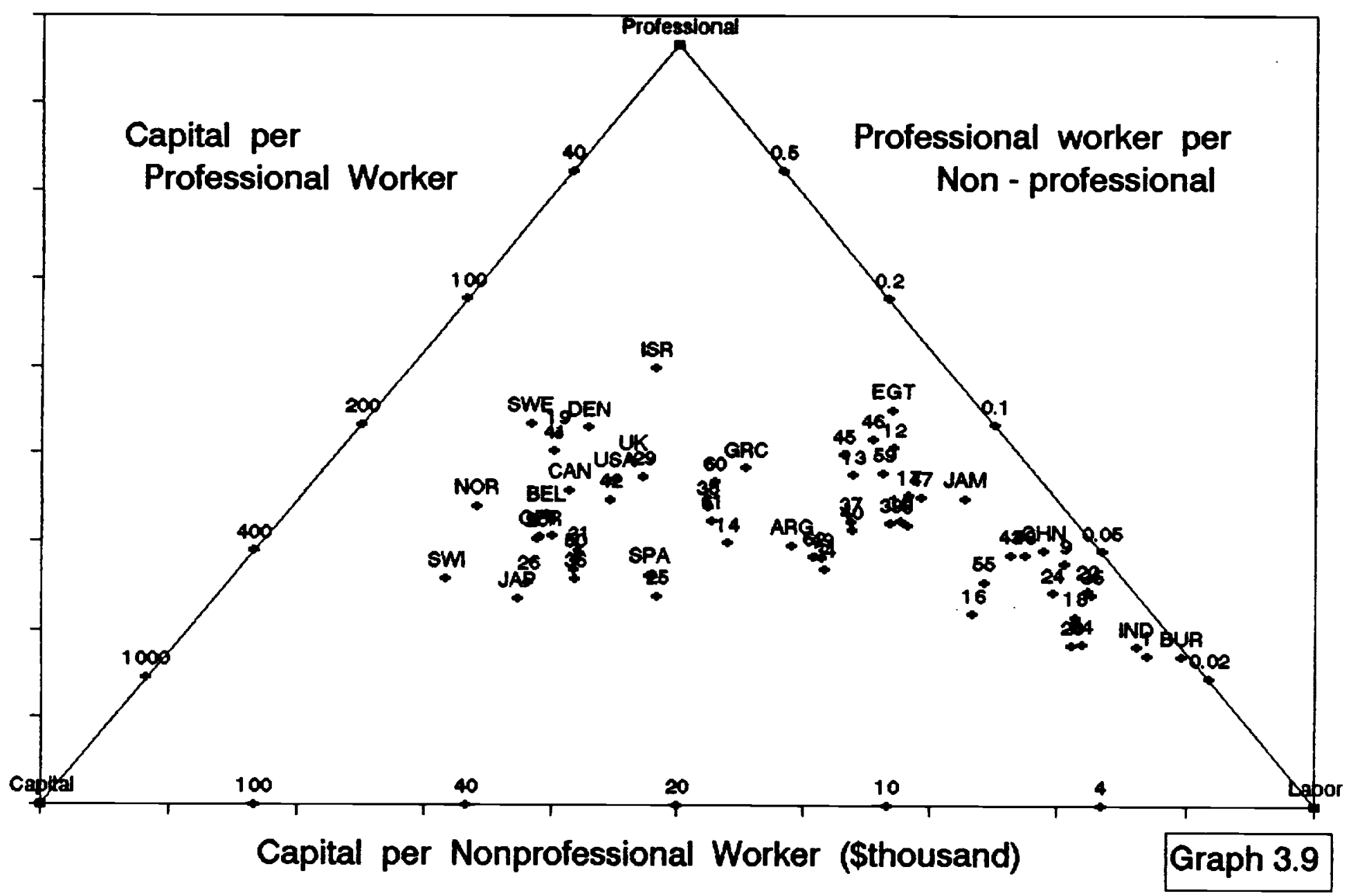


Net Exports Per Worker

Sweden - 1958

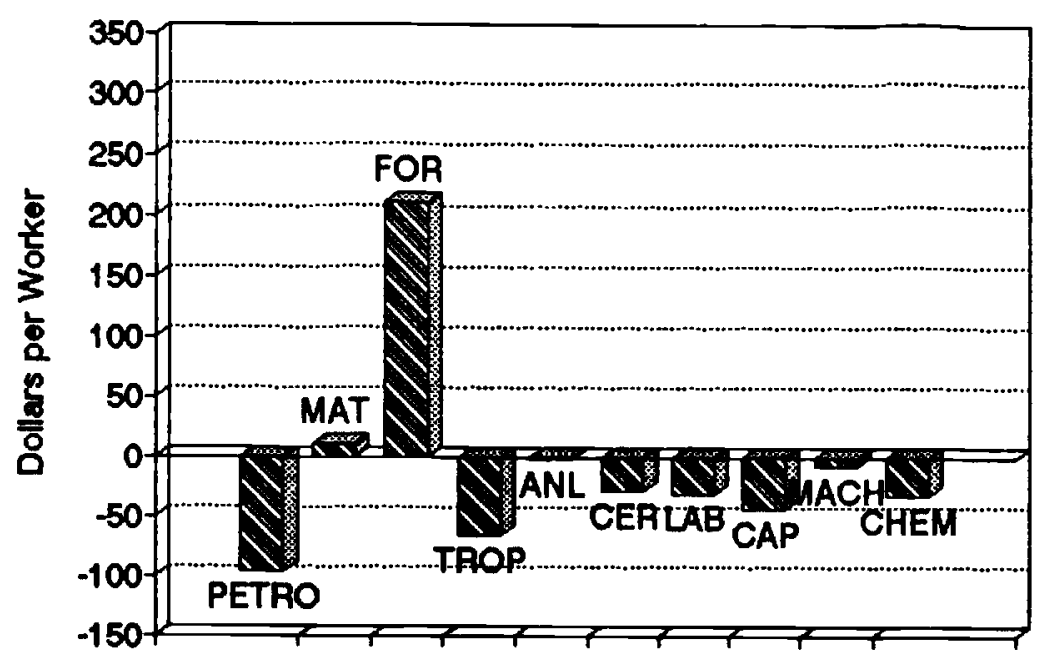

Net Exports Per Worker

USA - 1958

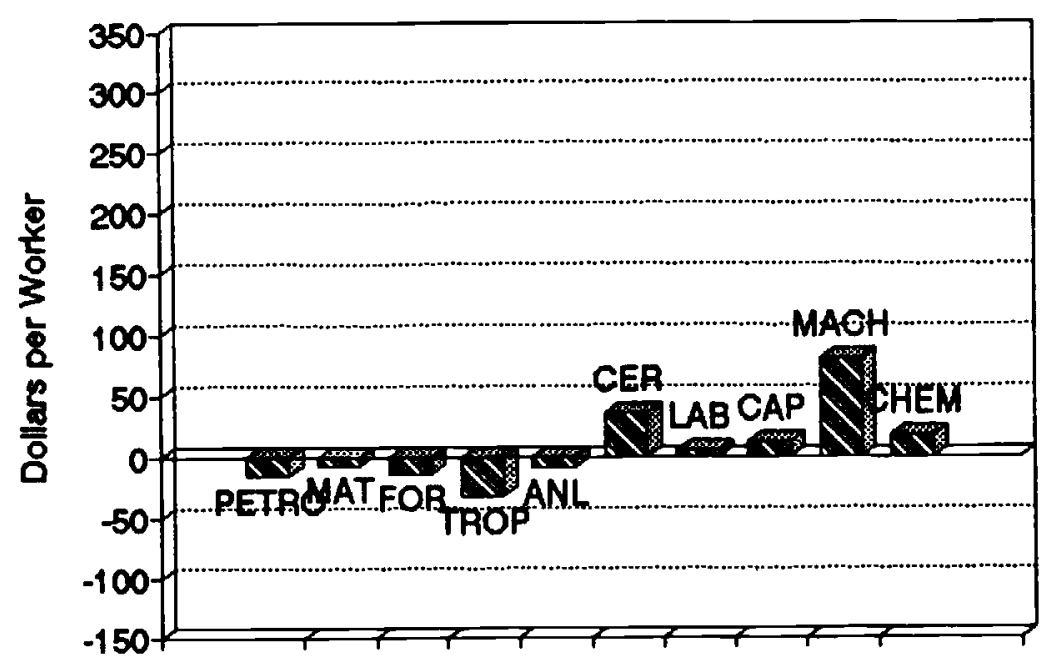

Net Exports Per Worker

Germany - 1958

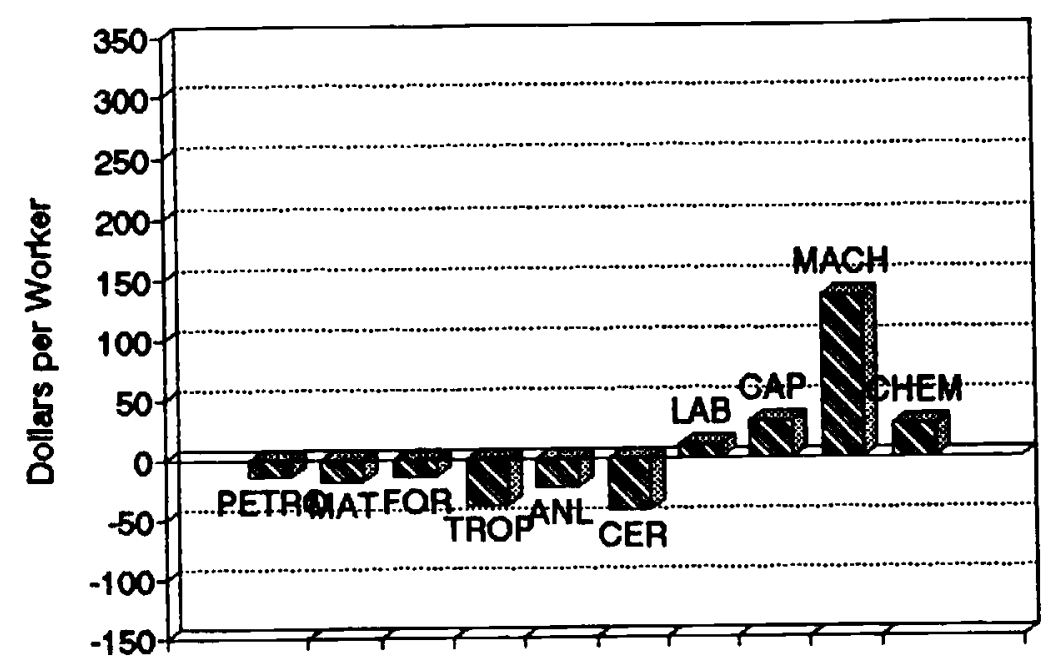

Net Exports Per Worker

Japan - 1958

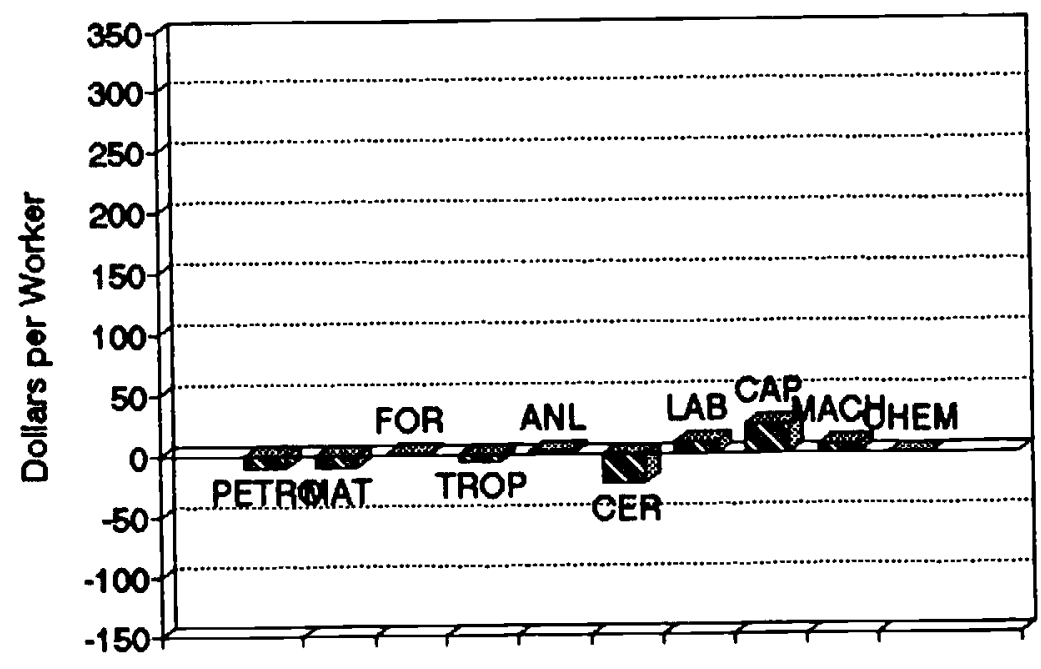


Net Exports Per Worker

Sweden - 1965

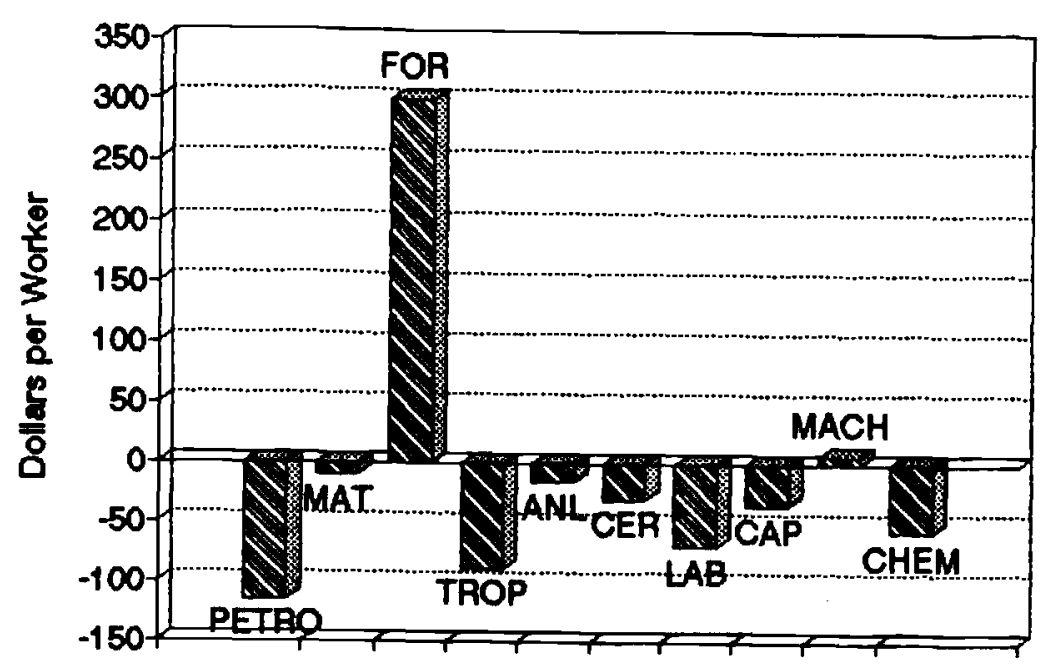

Net Exports Per Worker USA - 1965

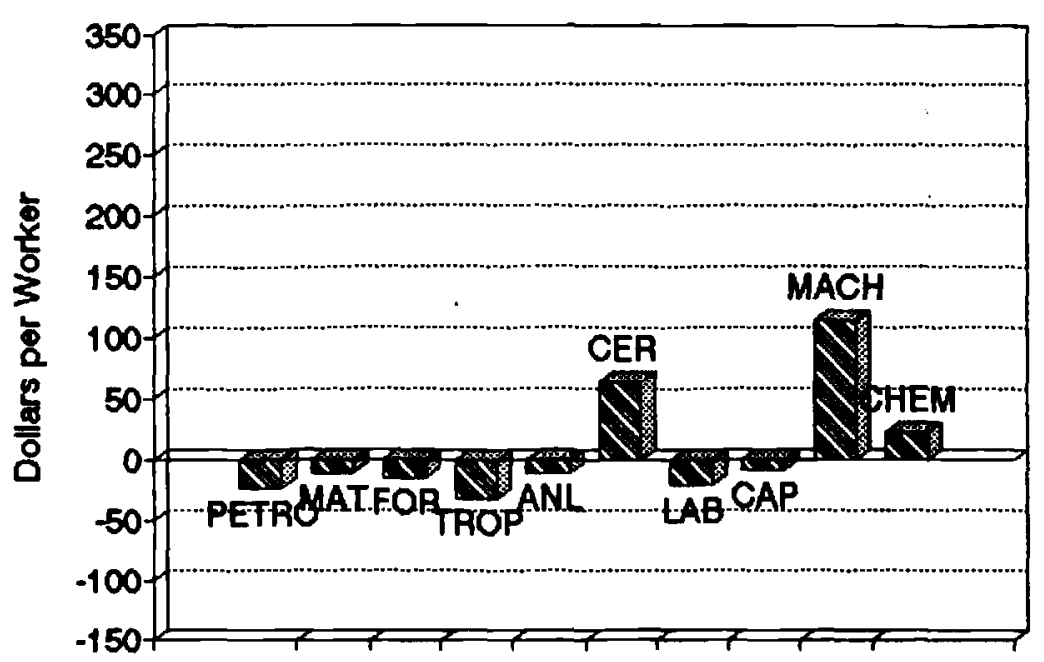

Net Exports Per Worker

Germany - 1965

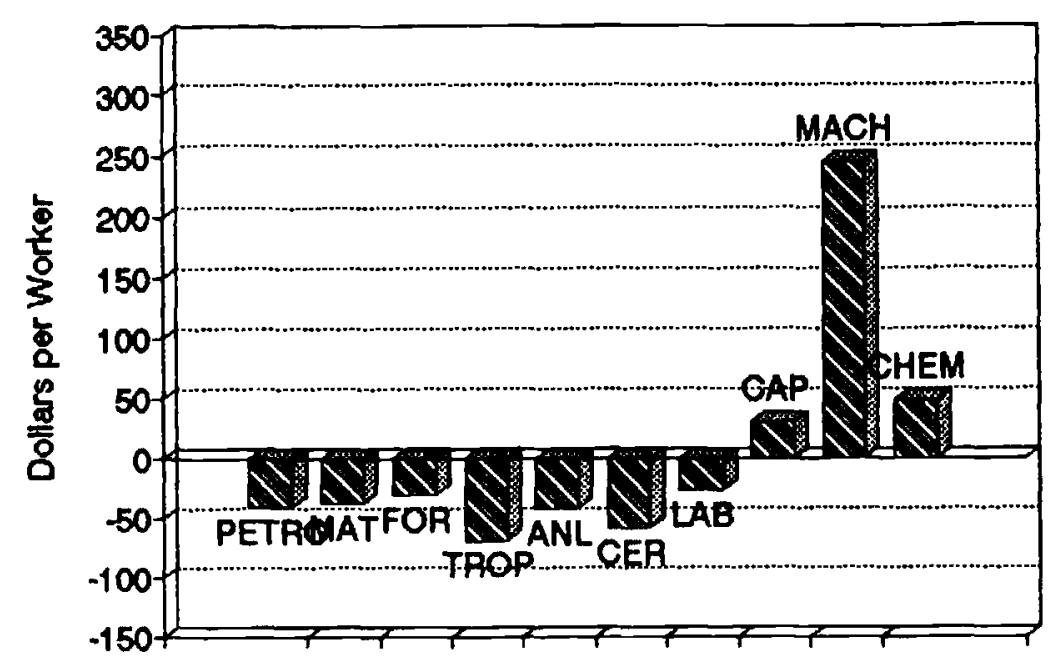

Net Exports Per Worker Japan - 1965

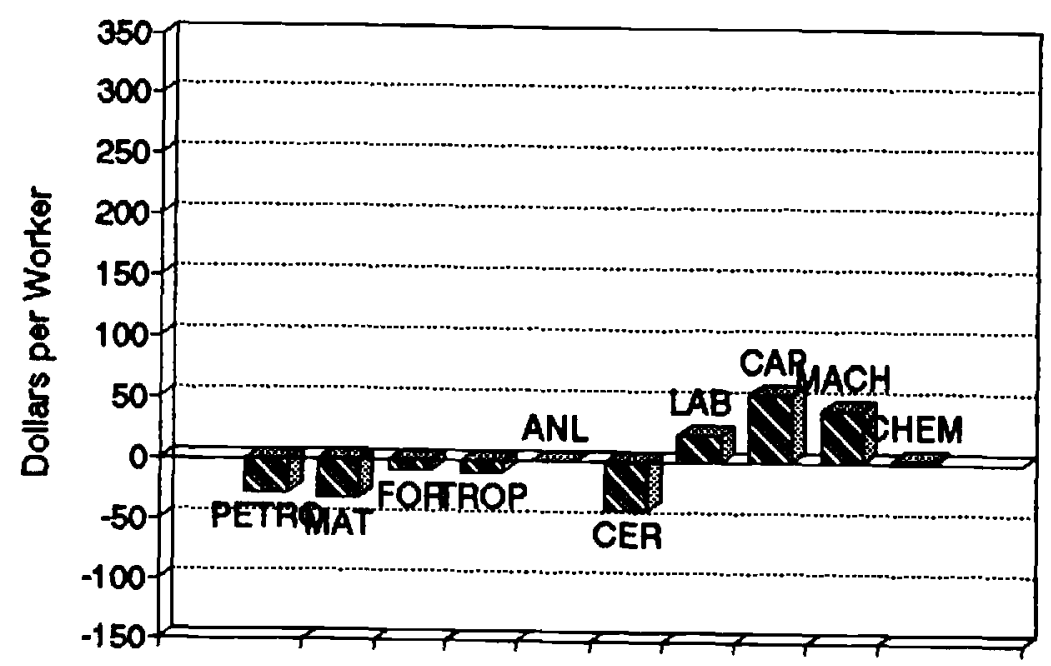


Net Exports Per Worker

Sweden - 1974

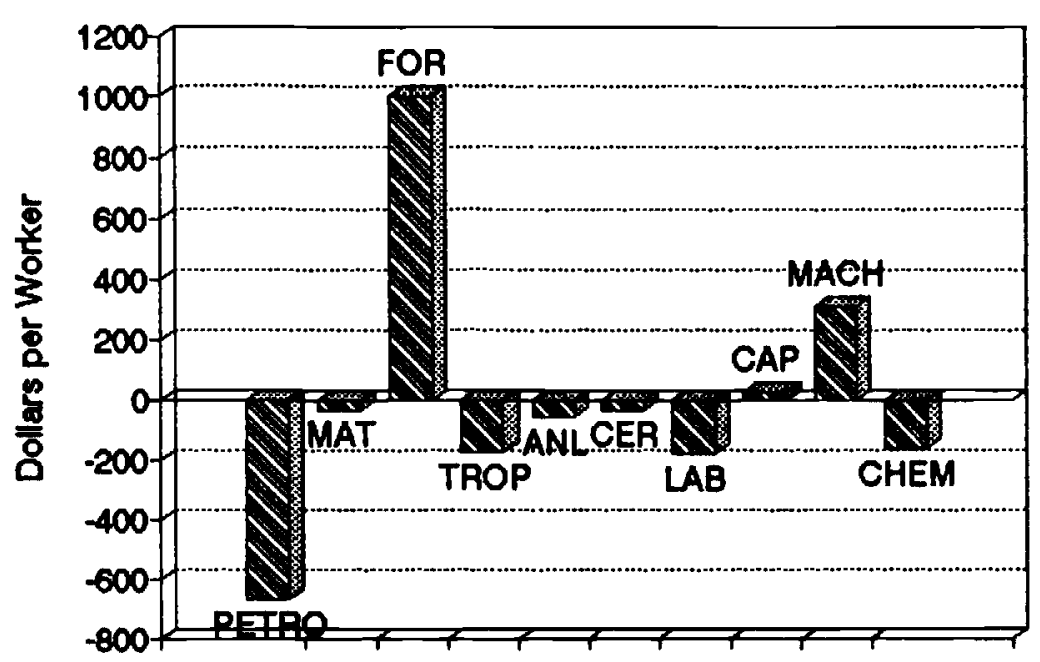

Net Exports Per Worker
USA - 1974

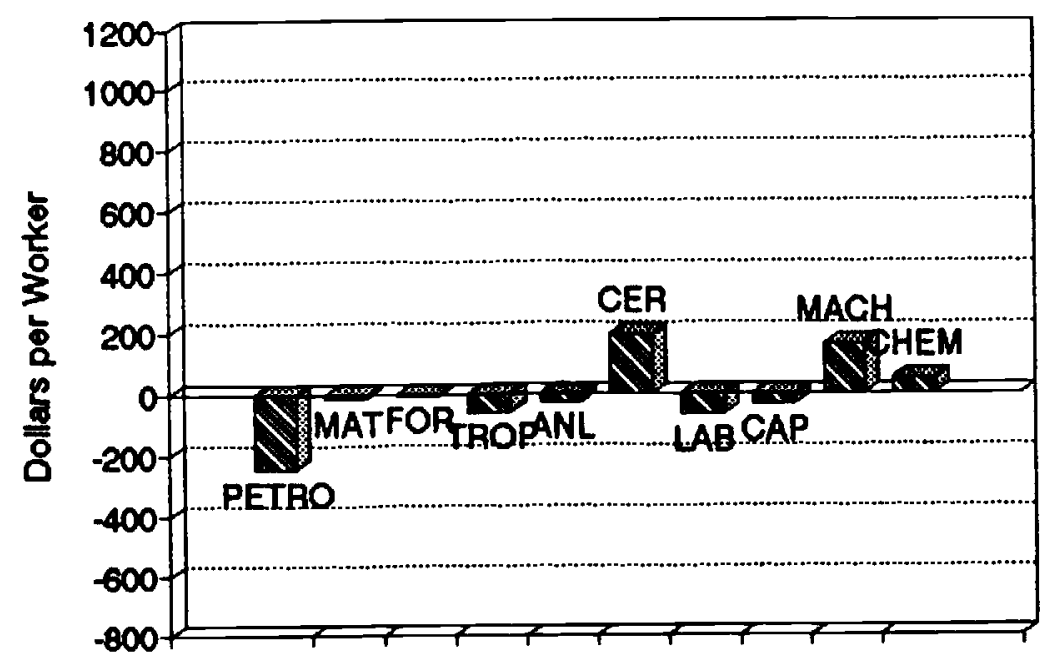

Net Exports Per Worker

Germany - 1974

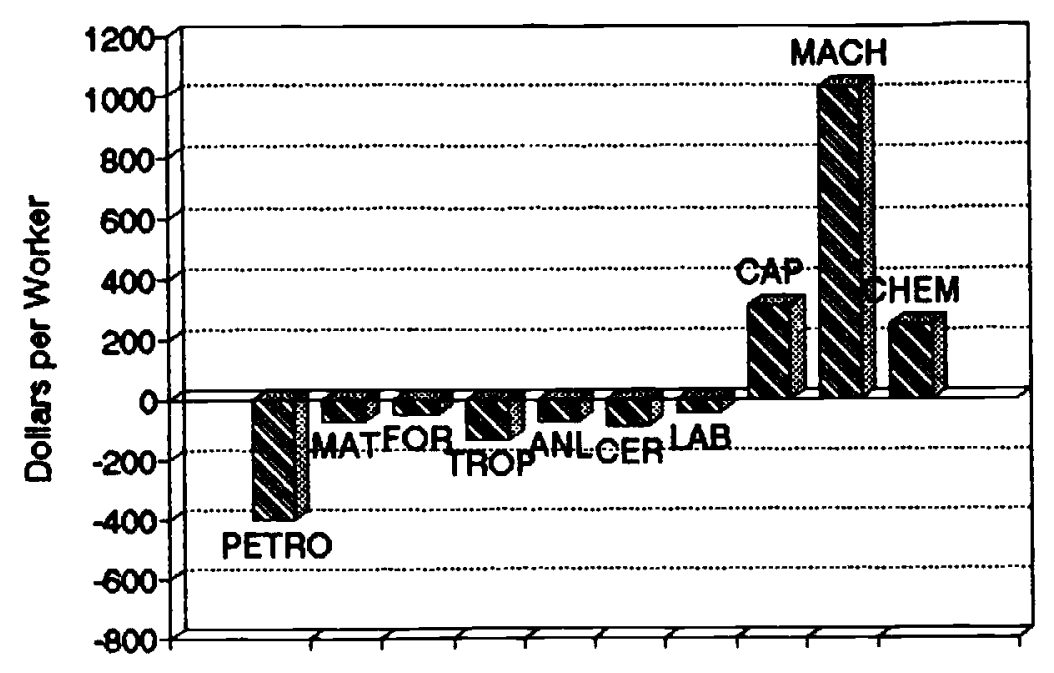

Net Exports Per Worker Japan - 1974

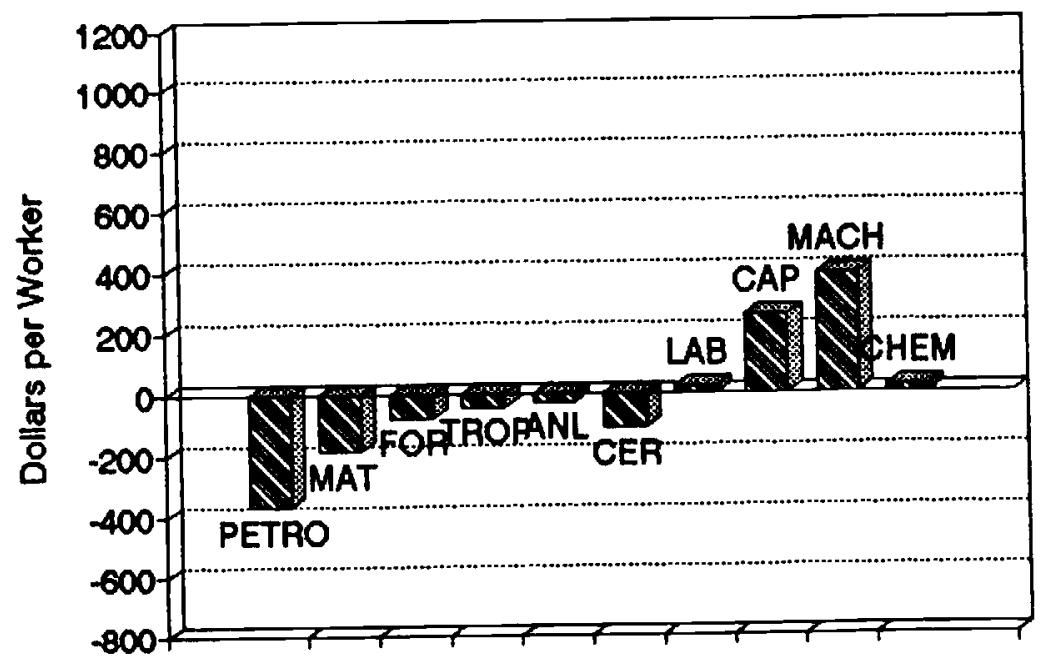


Net Exports Per Worker

Sweden - 1988

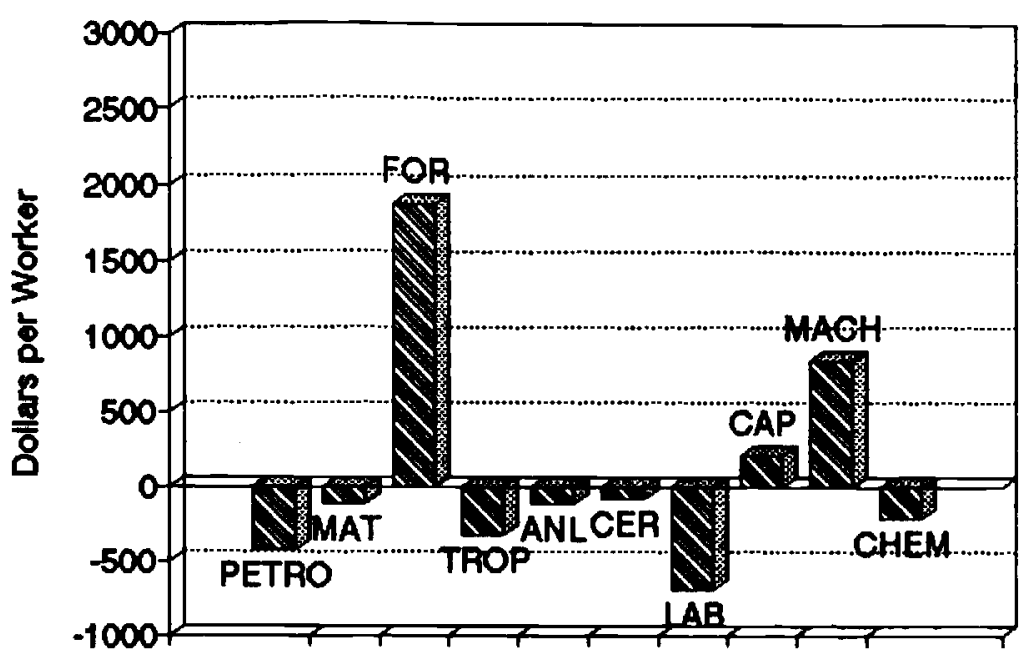

Net Exports Per Worker

USA - 1988

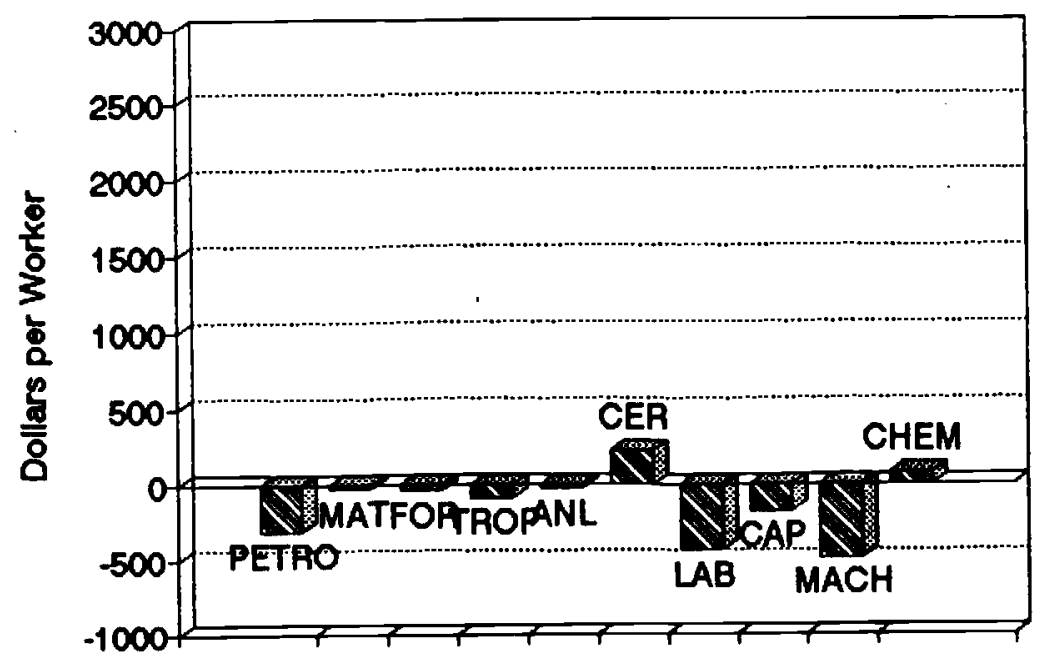

Net Exports Per Worker

West Germany - 1988

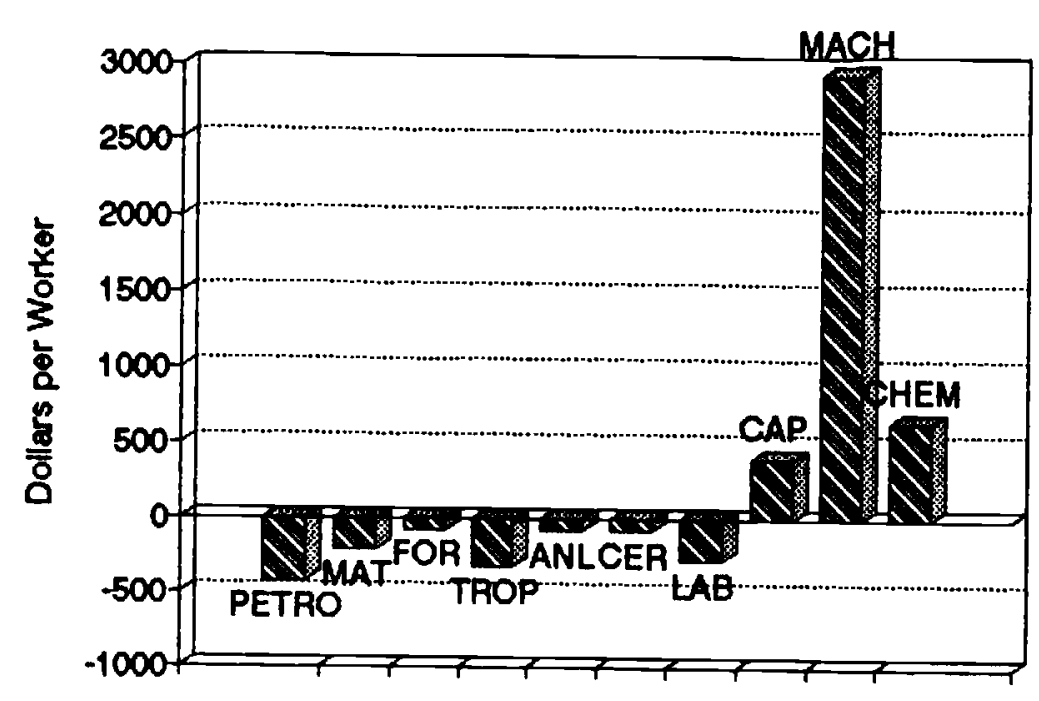

Net Exports Per Worker

Japan - 1988

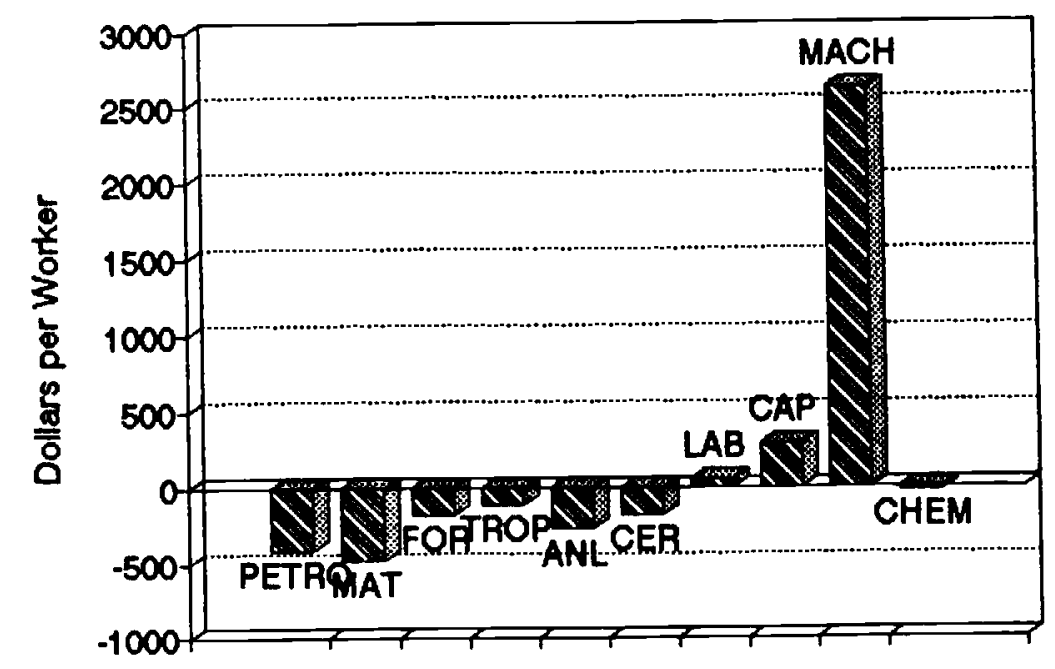




\section{GRAPH 3.14}

\section{Forest Product Net Exports Per Worker}

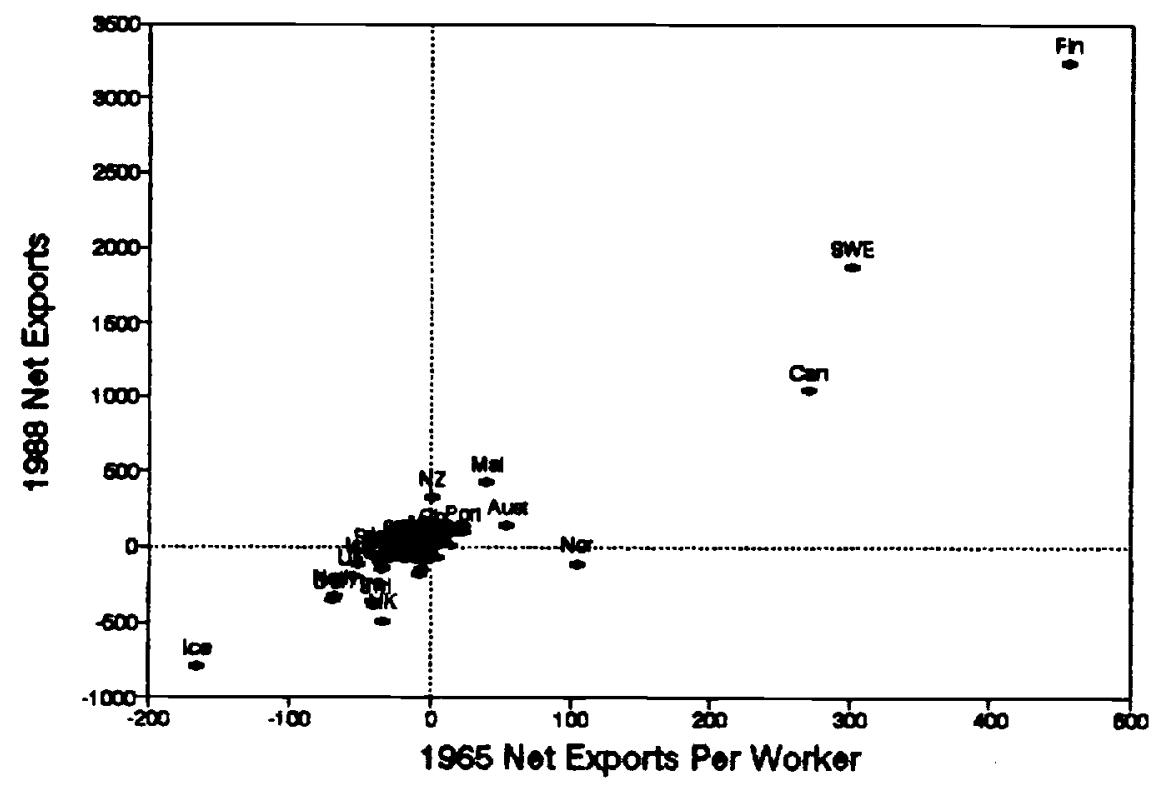

Full View

Forest Product Net Exports Per Worker

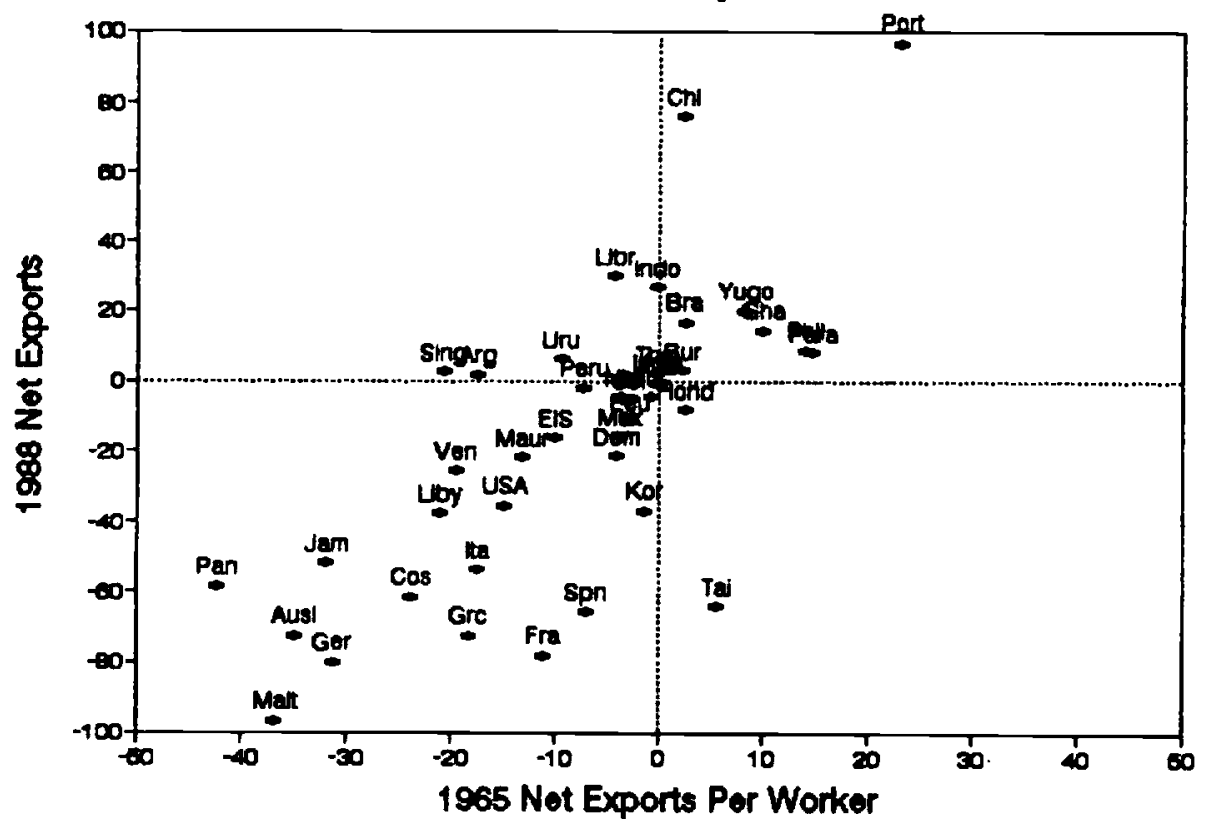

Zoomed

View 


\section{GRAPH 3.15}

\section{Labor-Intensive Net Exports Per Worker}

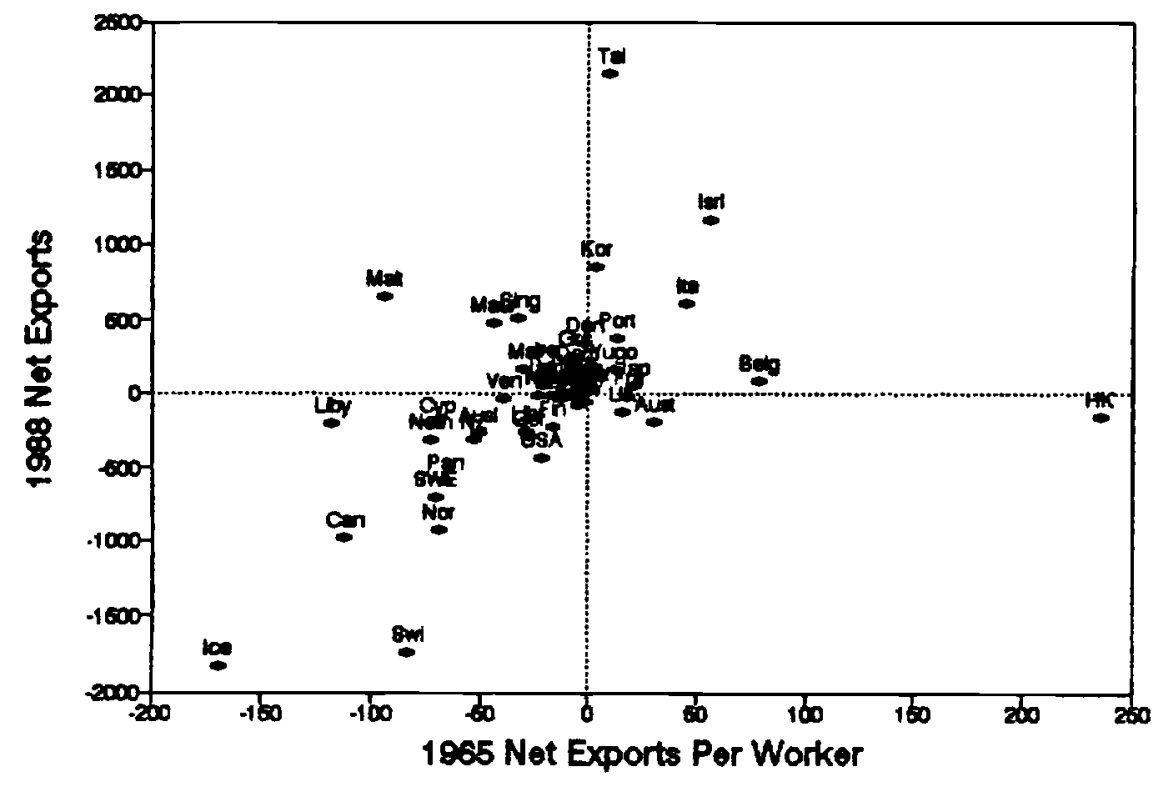

Full View

Labor-Intensive Net Exports Per Worker

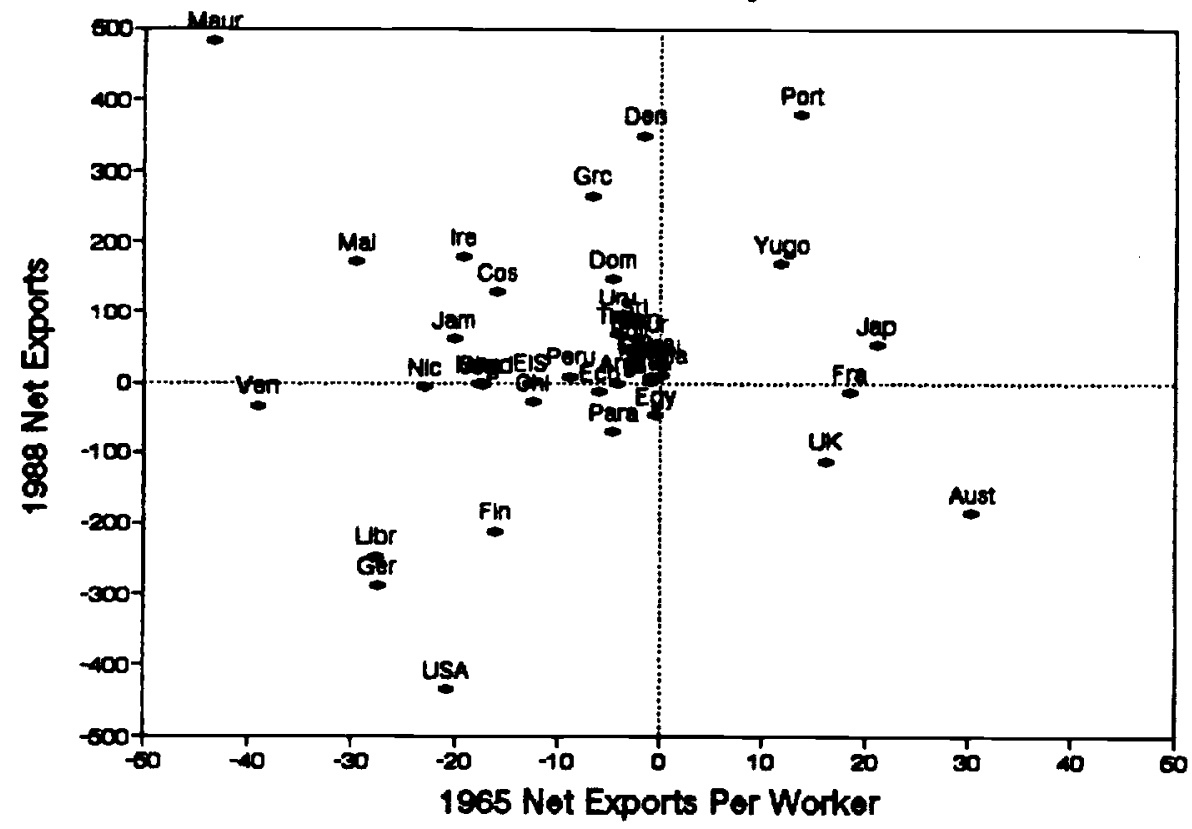

Zoomed

View 
GRAPH 3.16

Capital-Intensive Net Exp. Per Worker

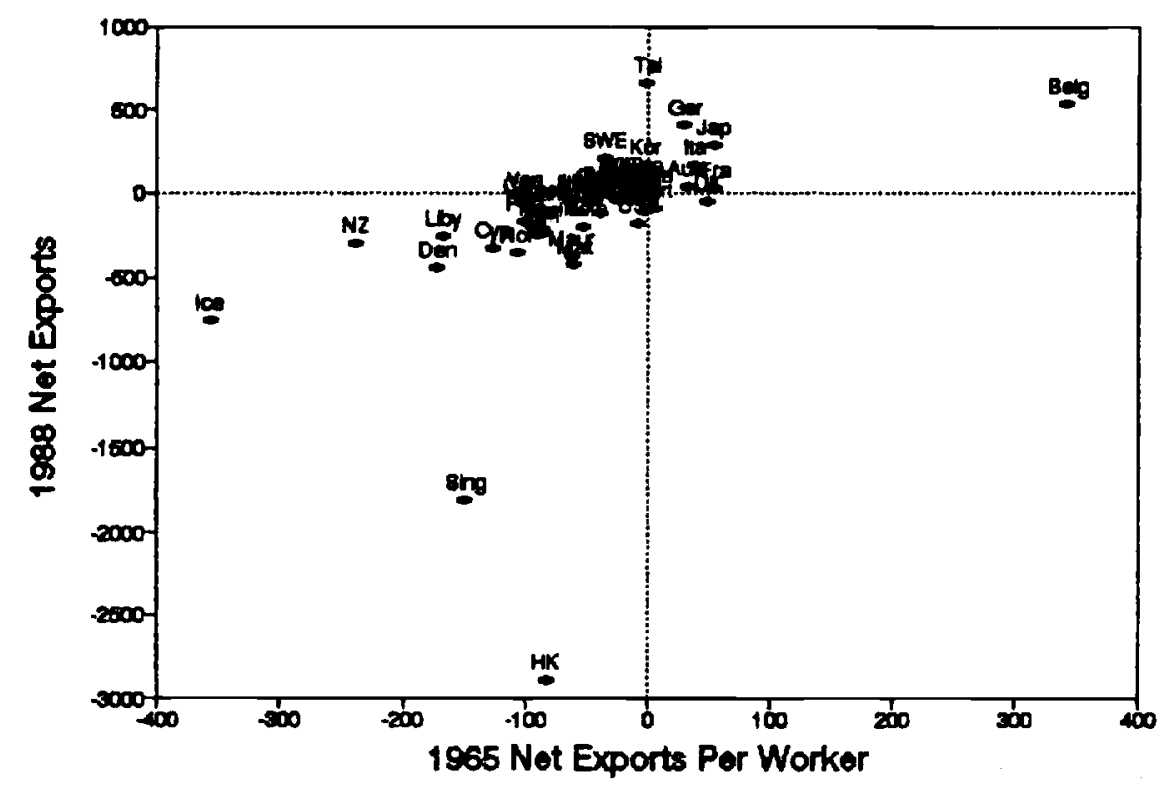

Full View

\section{Capital-Intensive Net Exp. Per Worker}

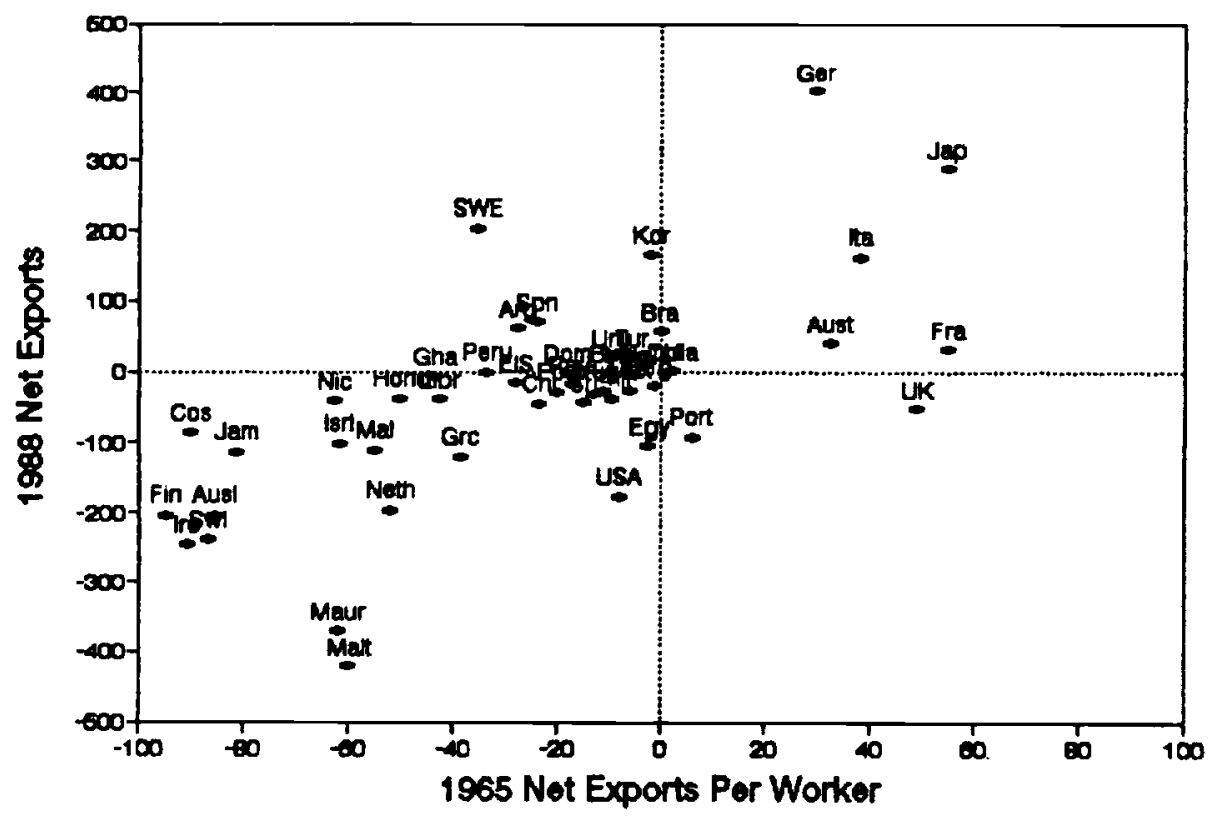

Zoomed View 
GRAPH 3.17

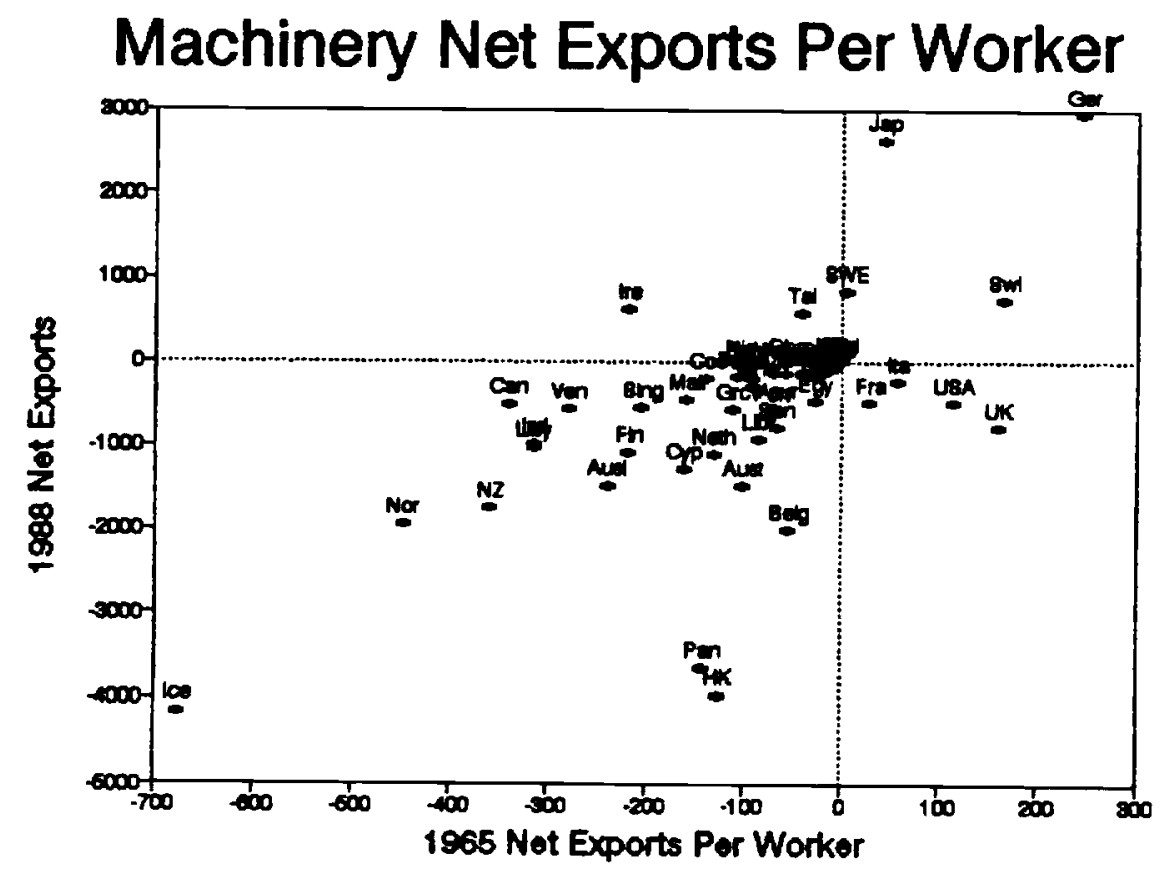

Full View

\section{Machinery Net Exports Per Worker}

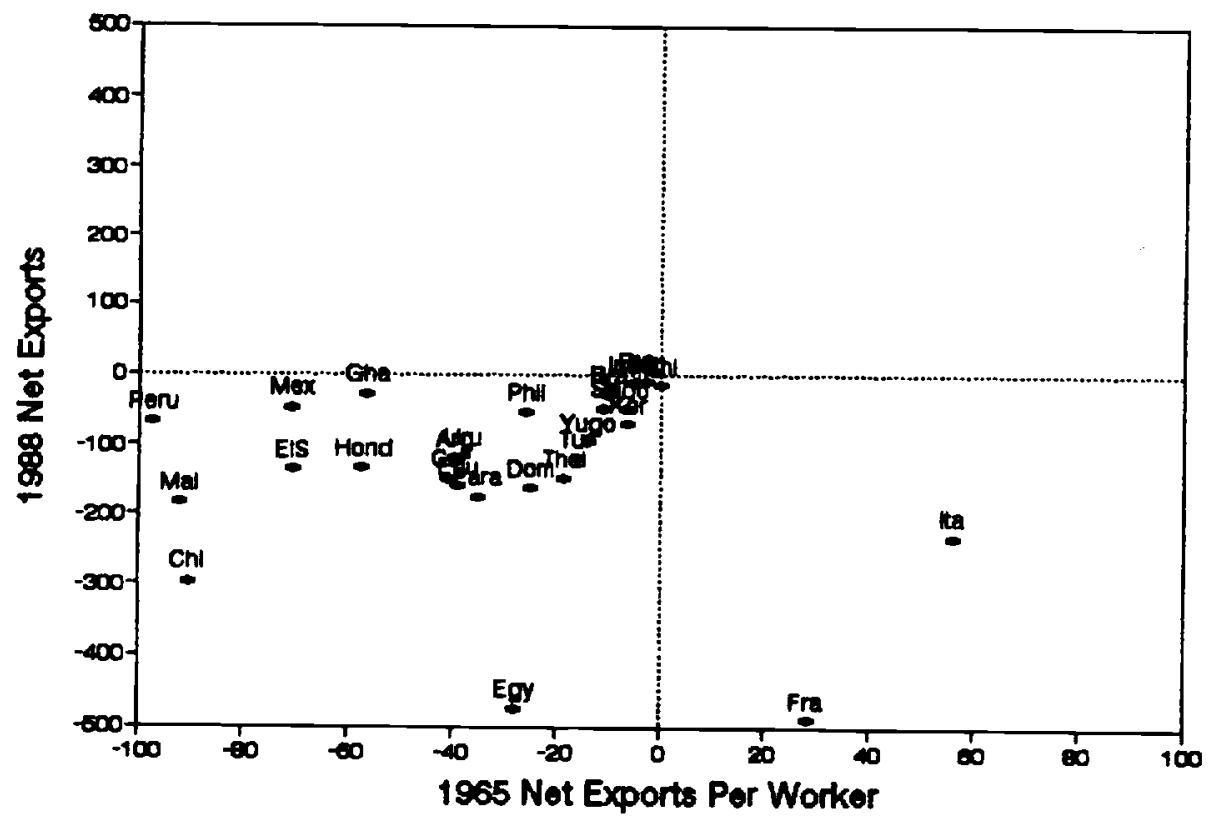

Zoomed

View 
GRAPH 3.18

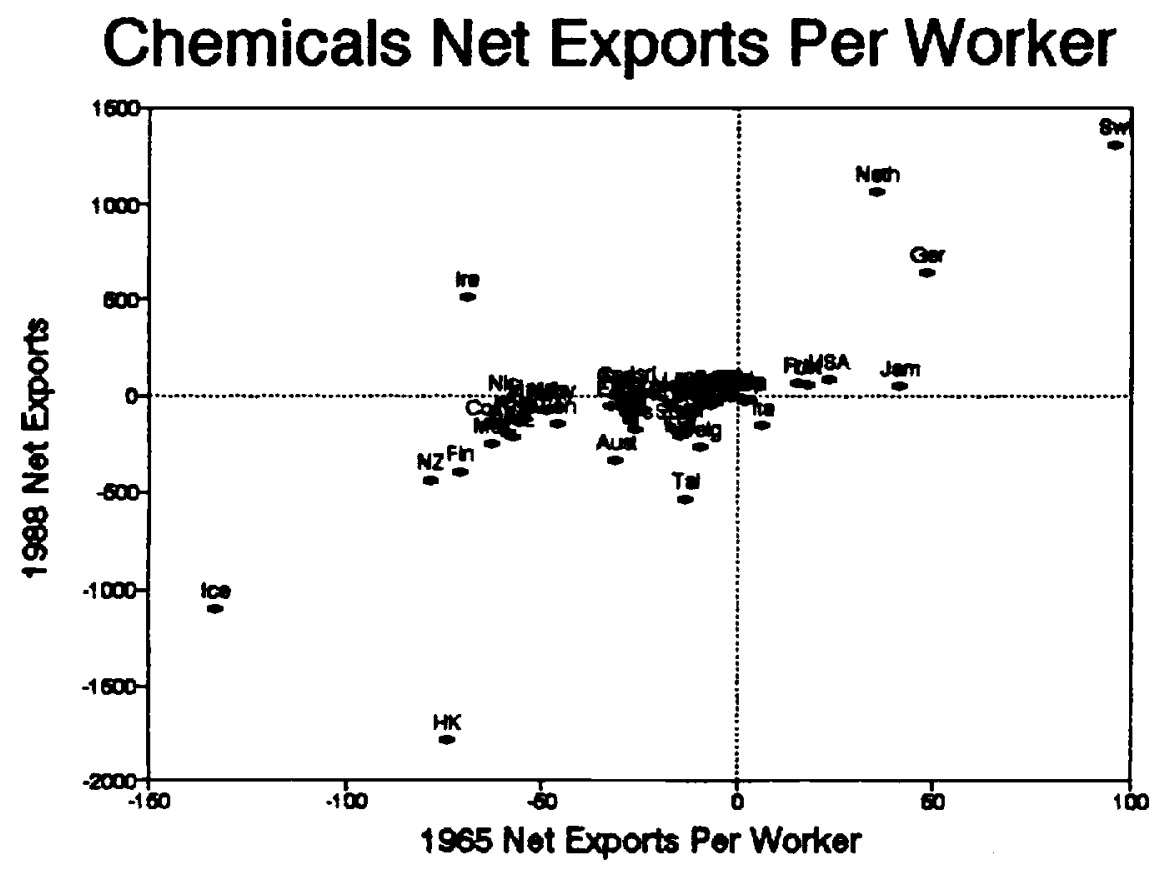

Full Viow

\section{Chemicals Net Exports Per Worker}

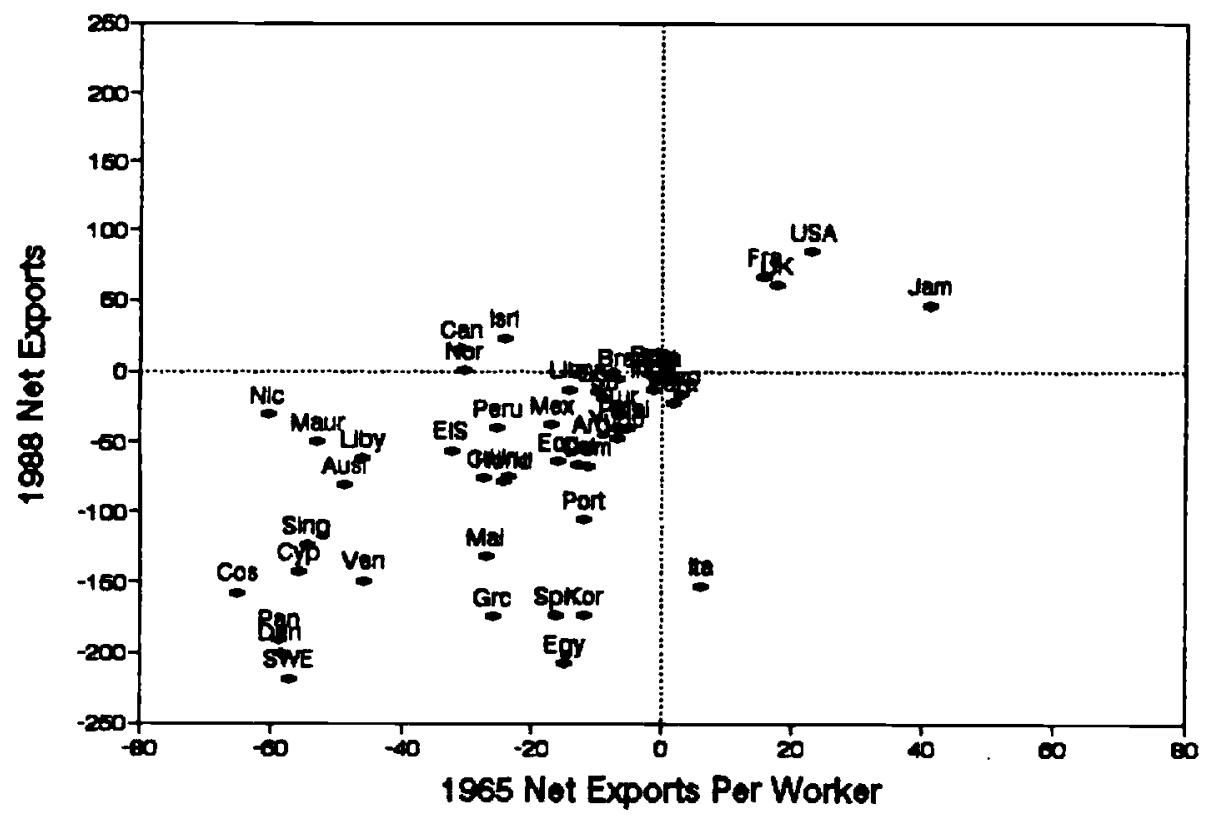

Zoomed

View 


\section{Swedish Terms-of-trade 1945-1992}

Incl. and excl. oil. 1959=100.
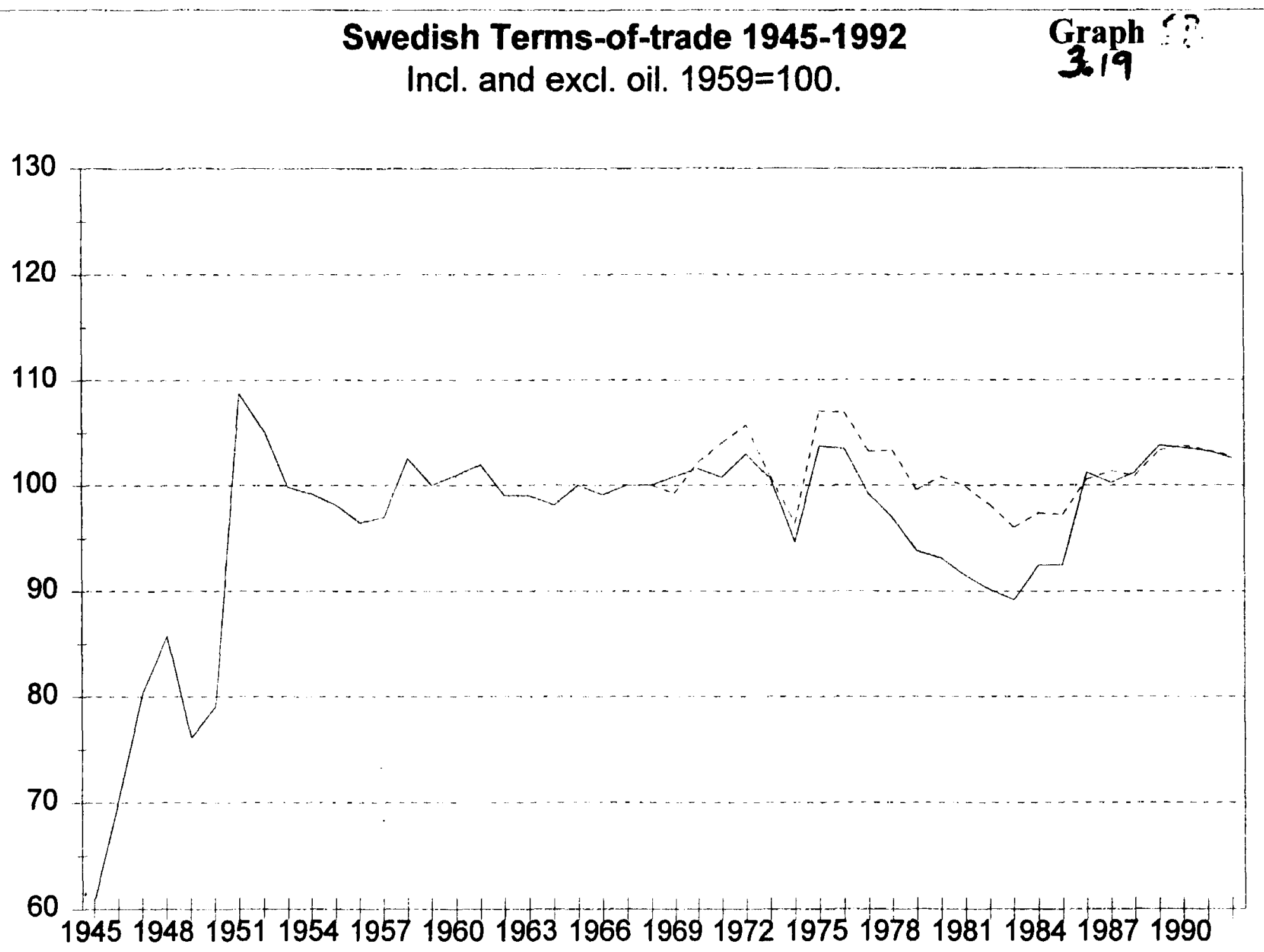

Terms-of-trade Terms-of-trade excl Oil 


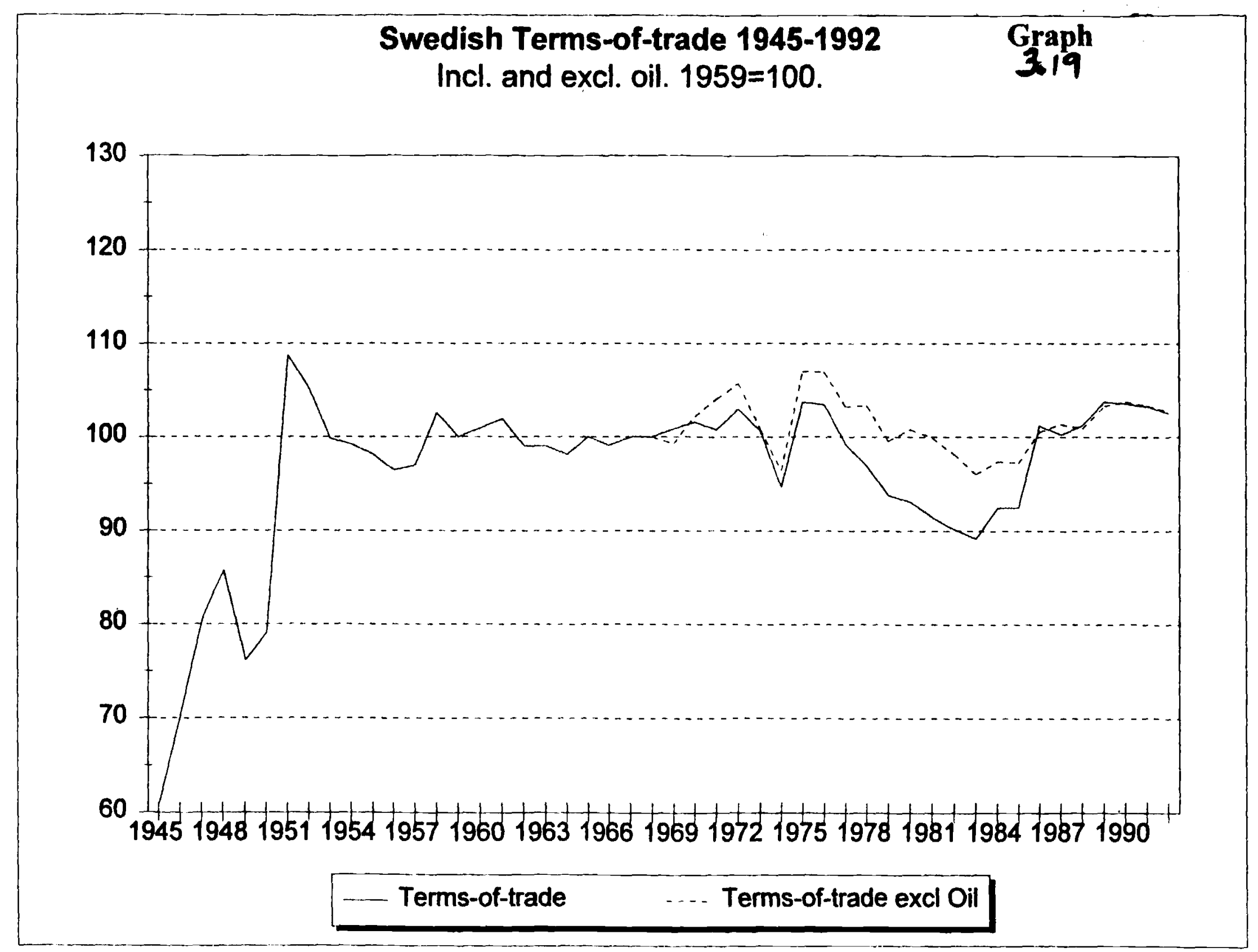


Graph 3.20

\section{Import and Export Price Indices \\ $1989(1968=100)$}

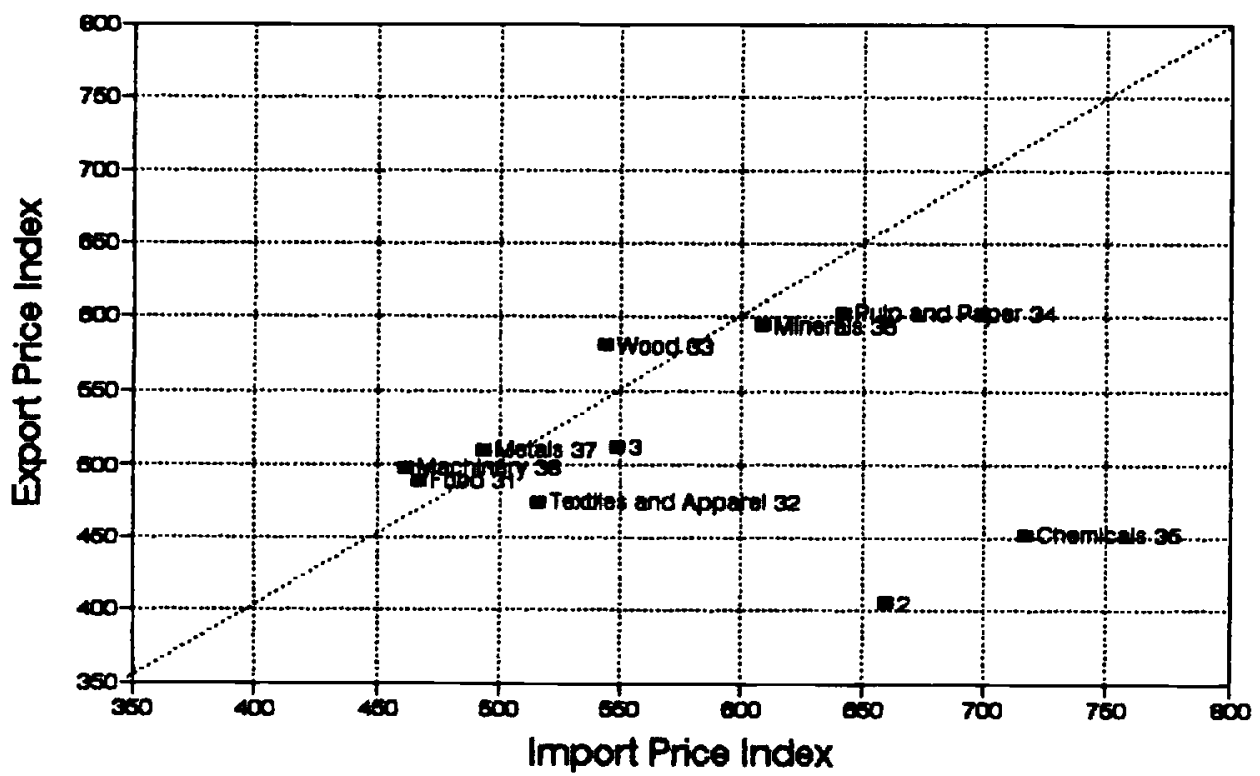

\section{Import and Export Price Indices $1992(1968=100)$}

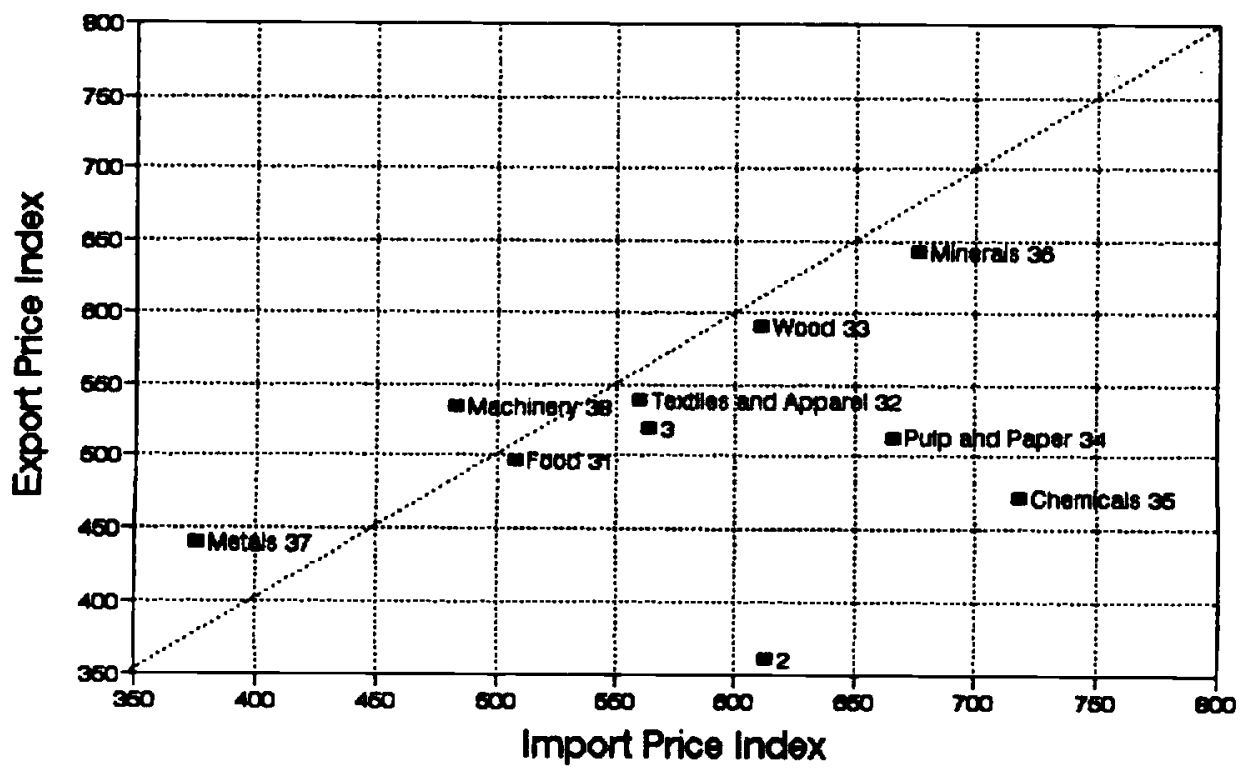


Graph 3.21

\section{Import and Export Price Indices $1989(1968=100)$}

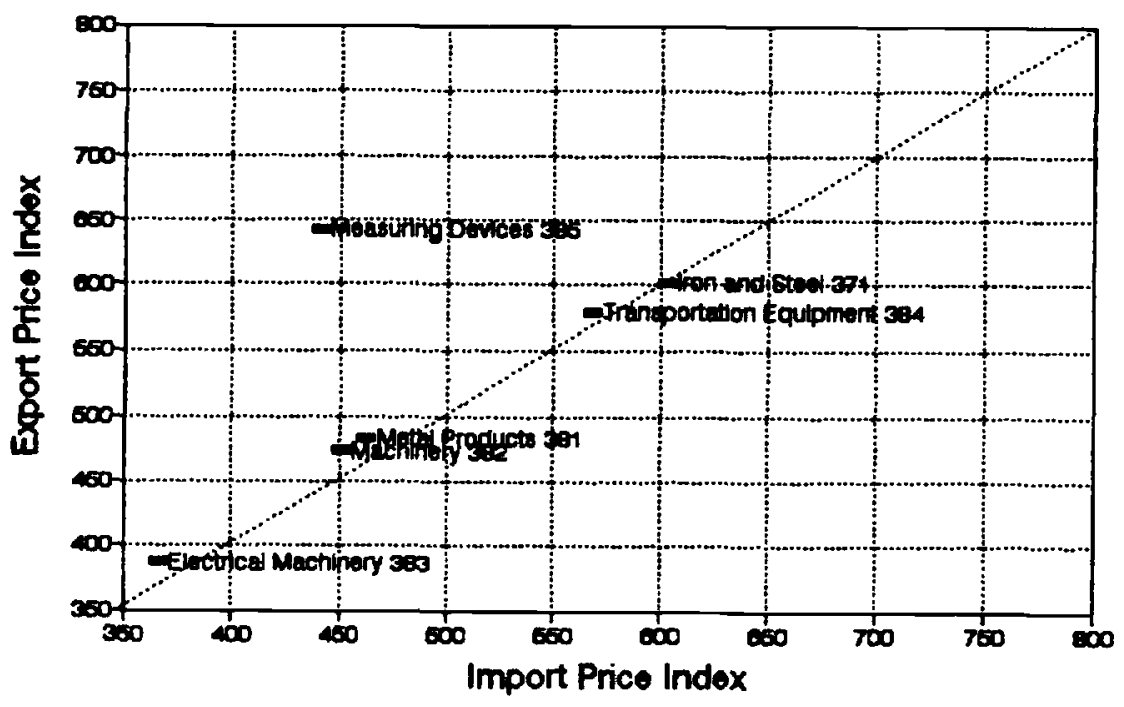

\section{Import and Export Price Indices $1992(1968=100)$}

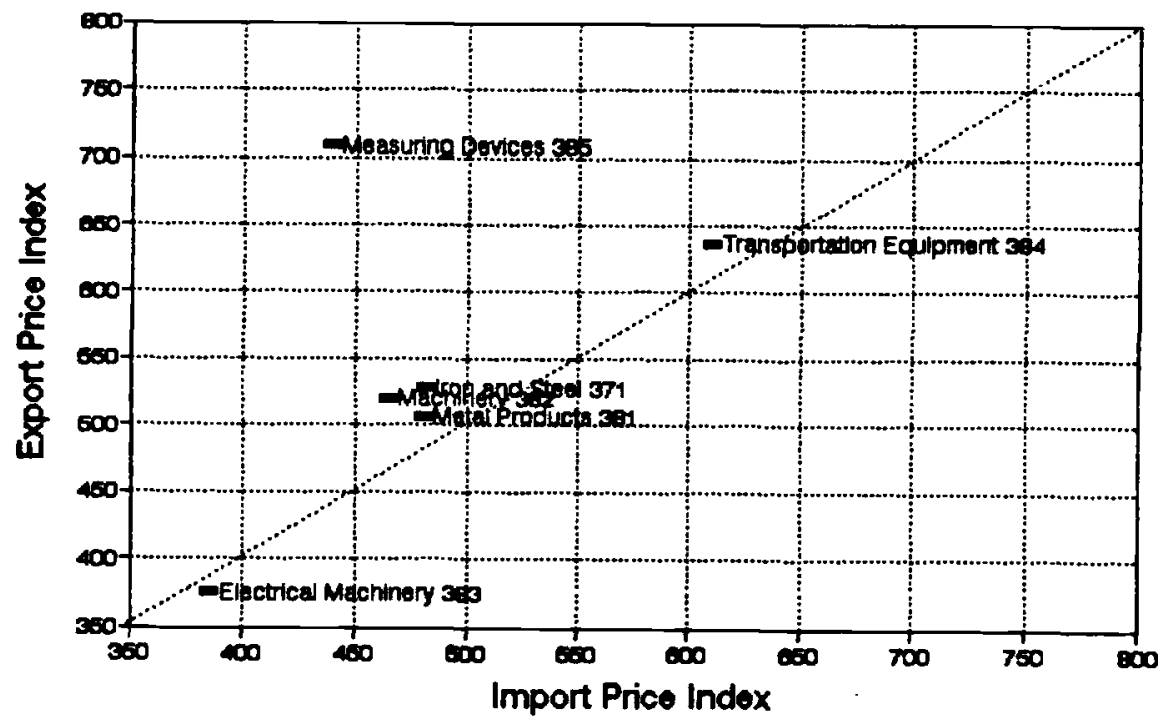




\section{Capital-Labor Ratios. ISIC 31-38 and for Manufacturing. Graph 5.1 Experiments 1-3}

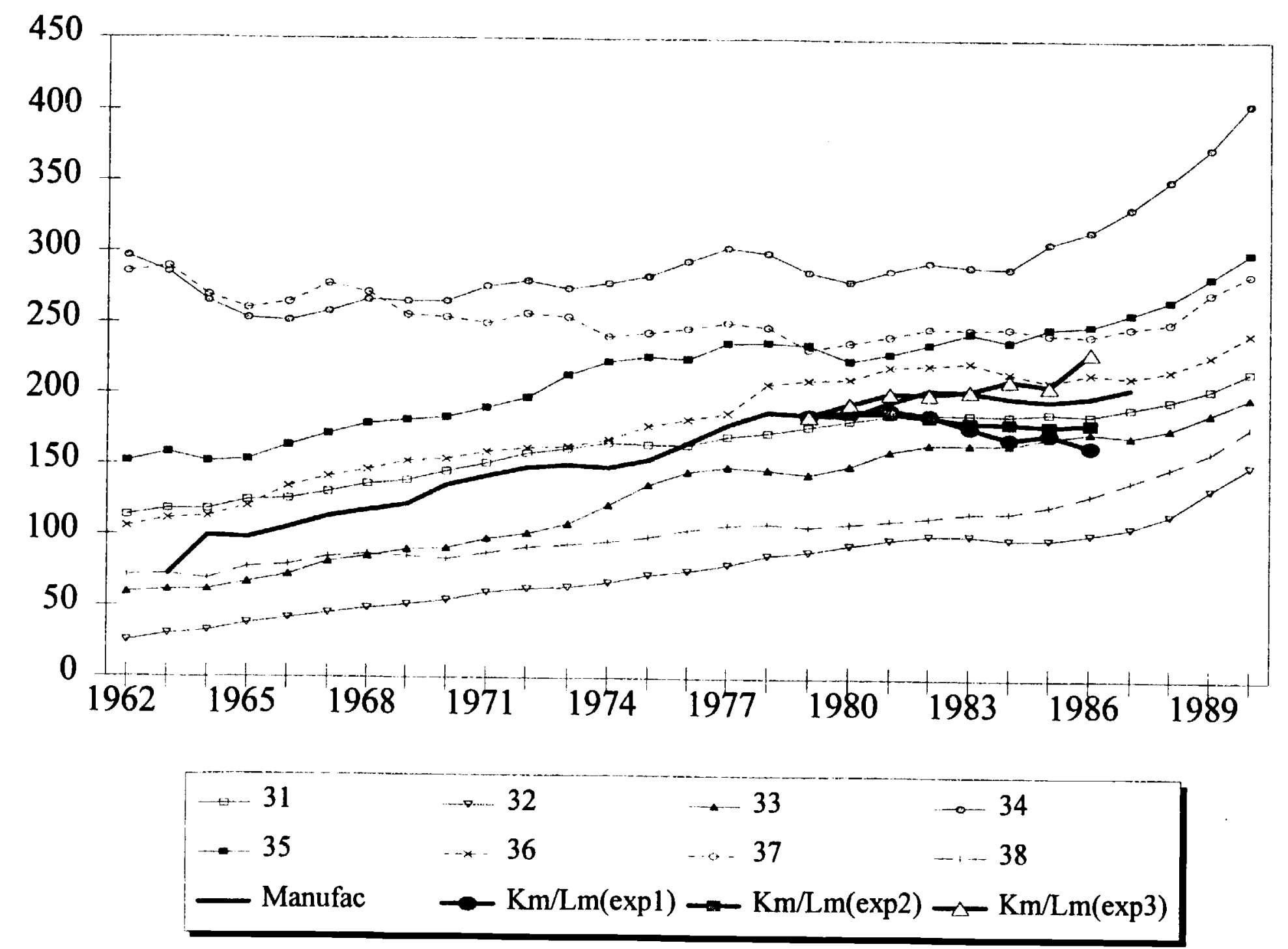




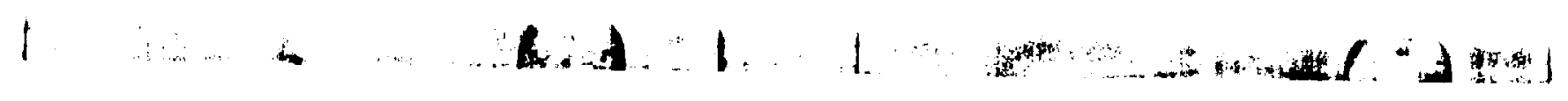

Manufacturing Production by Sector. In percent. 1962-1991

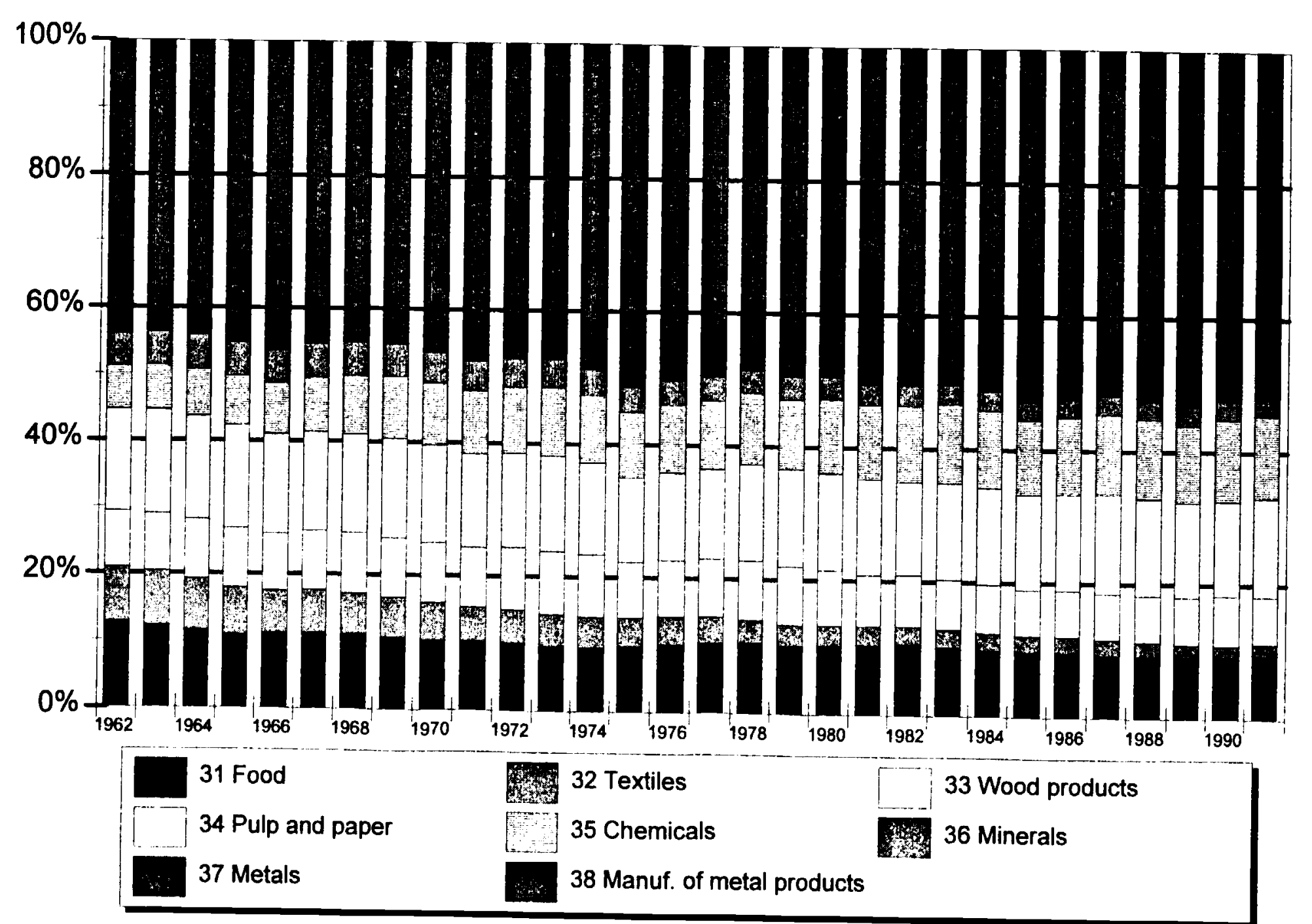

